\title{
HURRICANE SURVEY
}

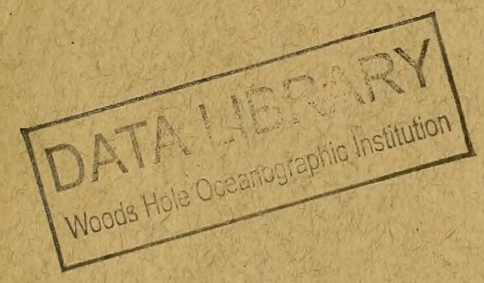

INTERIM

REPORT

\section{NARRAGANSETT BAY A R E $\bar{A}$}

RHODE ISLAND MASSACHUSETTS APPENDICES

HT

395

N3

148

1957

App.

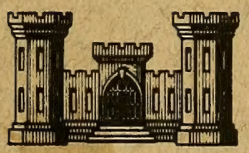

Corps of Engineers, U.S.Army - Office of the Division Engineer New England Division - Boston, Mass. 



\section{HURRICANE SURVEY}

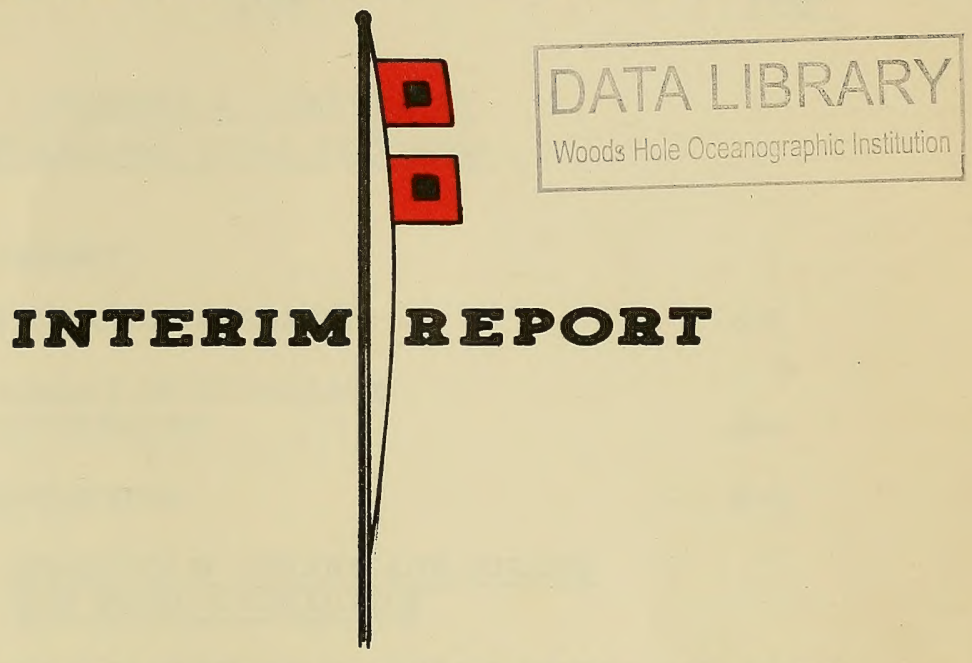

\section{NARRAGANSETT BAY A R E A}

RHODE ISLAND

MASSACHUSETTS

APPENDICES

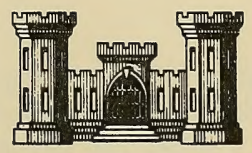

Corps of Engineers, U.S.Army - Office of the Division Engineer

New England Division - Boston, Mass.

15 FEBRUARY 1957 

APPENDIX A - HISTORY OF HURRICANE TIDAL FLOODING

\section{GLOSSARY}

A-1 HISTORICAL RESEARCH A-1

A-2 SUMMARY OF HURRICANE

OCCURRENCES A-1

A-3 DESCRIPTION A-2

APPENDIX B - HURRICANE SURGES AND TIDAL HYDRAULICS

NORMAL CONDITIONS IN NARRAGANSETT BAY

B -1

$\mathrm{B}-2$

$\mathrm{B}-3$

B -4

B -5

B -6

$\mathrm{B}-7$

B -8

B -9

B -10
General

Astronomical Tides

Fact ors Influencing Gravitational

Tides

Currents

Temperature

Salinity

Flushing

Silting

Recording Tide Gages In Narragansett

Bay

Corps of Engineers' Tide Gage Program
B-1

B -1

$\mathrm{B}-2$

$\mathrm{B}-2$

$\mathrm{B}-3$

$\mathrm{B}-3$

B -5

B -5

B -5

B -5

HURRICANE TIDAL FLOODING

B -11

$\mathrm{B}-12$

B -13

B -14

B -15
General

Hurricane of September 21, 1938

Hurricane of September 14, 1944

Hurricane of August 31, 1954

Frequency of Tidal Flooding
B -10

B -10

B -11

B-11

B -13 



\section{APPENDIX B (Cont'd)}

Paragraph

Title

$\underline{\text { Page }}$

DESIGN HURRICANE TIDAL FLOOD

B -16

$B-17$

B -18

B -19

B -20

$\mathrm{B}-21$

$\mathrm{B}-22$

$\mathrm{B}-23$

B -24

$\mathrm{B}-25$

$\mathrm{B}-26$

B-27
Wi nd Field

Storm Surge at Mouth of Bay

Storm Surge in Narragansett Bay

Selection of Design Storm Surge

Waves
B -20

$\mathrm{B}-20$

$\mathrm{B}-21$

$\mathrm{B}-21$

B -22

EFFECT OF BARRIERS ON TIDAL FLOODING

General

Description of Mode1

Model Testing Program

a. Middle Bay Barriers

b. Lower Bay Barriers

c. Field Point Barrier

d. Fox Point Barrier

Analytical Routings

Wind Set-Up

Overtopping

Summary

a. Fox Point Barrier

b. Lower Bay Barriers

(1) East Barrier

(2) West Barrier

(3) Tiverton Barrier
B -22

$\mathrm{B}-23$

$\mathrm{B}-23$

B -23

B -24

B -24

B -24

B -24

B -25

B -26

B -26

B -27

B -27

B -27

B -27

B -27

EFFECT OF BARRIERS ON NORMAL CONDITIONS

$\mathrm{B}-28$

B -29

$\mathrm{B}-30$

$\mathrm{B}-31$

$\mathrm{B}-32$

$\mathrm{B}-33$
General

Tides

Currents

Temperature

Salinity

Flushing
B -28

B -28

B -28

B -29

B-29

B -29 

APPENDIX C - HYDROLOGY AND

STREAM FLOW

C - 1

C -2

C -3

C -4

C -5

C -6

C -7

C - 8

C -9

D-2

D-3

D-1
Introduction

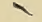

C -1

Temperature and Precipitation

C -1

Runoff and Stream Flow

C - 2

Hurricane Rainfall

C -4

Hurricane Runoff

a. September 1938 Flood

C -4

C -5

b. September 11, 1954 Flood (Edna)

C -5

c. August 19, 1955 Flood (Diane)

C -5

Design Storm

C -5

Design Flood for Fox Point Barrier

a. Woonasquatucket River

C -6

C -6

b. Moshas suck River

C -7

Design Flood for Lower Bay Barriers

C -7

a. Blackstone River

C -7

b. Woonasquatucket and Moshassuck Rivers

C -8

c. Pawtuxet River

C - 8

d. Taunton River

C -8

Design Stream Flow

C -9

a. Fox Point Barrier

C -9

b. Lower Bay Barriers

\section{APPENDIX D - FLOOD LOSSES AND BENEFITS}

Measurement of Flood Damages

$\mathrm{D}-1$

a. Damage Surveys

$\mathrm{D}-1$

b. Loss Classification

$\mathrm{D}-1$

Experienced Damages

$\mathrm{D}-2$

a. Tidal-Flood Losses

$\mathrm{D}-2$

b. Providence, Rhode Island

$\mathrm{D}-3$

c. West Side: Narragansett Bay

$\mathrm{D}-3$

d. East Side: Narragansett Bay

D-7 and Mount Hope Bay

D-10

Recurring Damages

$\mathrm{D}-10$

b. Evaluation of Individual FloodProtection Measures

D-11

c. Normal Recovery

$\mathrm{D}-12$

d. Normal Growth 



\section{APPENDIX D (Cont'd)}

$\underline{\text { Paragraph }}$

$$
\text { Title }
$$

$\underline{\text { Page }}$

$\mathrm{D}-4$

Annual Losses and Benefits

$\mathrm{D}-12$

a. General

$\mathrm{D}-12$

b. Average Annual Losses

D-13

c. Average Annual Flood-Prevention

Benefits

$\mathrm{D}-13$

d. Scare Cost Benefits

$\mathrm{D}-16$

APPENDIX E - GEOLOGY AND FOUNDATION DATA

PART I - NARRAGANSETT BAY

$E-1$

$\mathrm{E}-2$

E-3

$\mathrm{E}-4$

$E-5$

$\mathrm{E}-6$

$\mathrm{E}-7$

$\mathrm{E}-8$

E-9
Physiography and Geology

Subsurface Investigations

General Foundation Conditions

Geology of the Fox Point Site

Geology of the East Barrier Site

Geology of the West Barrier Site

Availability of Quarry Stone

Availability of Concrete Aggregates

a. Fox Point Site

b. Lower Bay Site

Conclusions and Recommendations

a. Foundation Explorations

(1) Fox Point

(2) West Barrier

(3) East Barrier

b. Quarry Development

c. Inherent Physical Geological Changes
$\mathrm{E}-1$

$E-2$

$\mathrm{E}-2$

$\mathrm{E}-2$

$\mathrm{E}-3$

$\mathrm{E}-4$

$\mathrm{E}-4$

$E-5$

$E-5$

E-6

E-6

E-6

E-6

E-6

$E-6$

$\mathrm{E}-7$

$\mathrm{E}-7$

PART II - SAKONNET RIVER

E-10

E-11

$\mathrm{E}-12$

$\mathrm{E}-13$

E-14

$\mathrm{E}-15$

E-16
Physiography and Geology

Subsurface Investigations

Geology of the Tiverton Site

Availability of Quarry Stone

Availability of Concrete Aggregates

Availability of Earthen Borrow

Conclusions and Recommendations
$E-7$

$E-7$

$E-8$

E-8

E-8

E-9

E-9 

AND COST ESTIMATES

Paragraph

F-1

F-2

F-3

F-4

F-5

F-6

F-7

$F-8$

F-9

F-10

$F-11$

F -12

F -13

F-14
Title

Page

INTRODUCTION

$\mathrm{F}-1$

$F-1$

$F-1$

BASIS OF COST ESTIMATES

Cost Estimates

F-2

Unit Prices

$\mathrm{F}-2$

Contingencies, Engineering and Overhead

$\mathrm{F}-2$

Annual Charges

$\mathrm{F}-3$

FOX POINT BARRIER

Description and Pertinent Data

F-3

a. General

F-3

b. Barrier

$F-3$

c. Sluice Gate Structure

F -3

d. Cooling Water Intake Structure

F -3

e. Pumping Station

F -4

f. Land Walls

$\mathrm{F}-4$

g. Pertinent Data

F -4

Design

F-5

a. General

F-5

b. Barrier

F-5

c. Sluice Gate Structure

F -5

d. Cooling Water Intake Structure

F-5

e. Pumping Station

F-5

f. Foundations

F-6

g. Land Walls

F-6

Modifications to Sewers and Drainage

F-6

Lands and Damages

F-6

Plan of Construction

F-6

Operation and Maintenance

F -7

Cost Estimates 

APPENDIX F - DESIGN STUDIES

AND COST ESTIMATES (Cont'd)

$\underline{\text { Paragraph }}$

Title

Page

F-15

Alternative Plans for Fox Point

F-7

A. General

F-7

b. Alignment No. 1

F -12

c. Alignment No. 2

$\mathrm{F}-12$

d. Rock and Earth Fill Barriers

$\mathrm{F}-12$

e. Concrete Barriers

$F-12$

f. Control of Level of Providence River

F-12

LOWER BAY BARRIERS

F-16

$F-17$

$F-18$

F -19

F -20

East Barrier

F -12

a. Description and Pertinent Data

$\mathrm{F}-12$

b. Lands and Damages

F -13

West Barrier

F -13

a. Description and Pertinent Data

F-13

b. Lands and Damages

F-14

$\mathrm{F}-14$

a. Description and Pertinent Data F-14

b. Lands and Damages F-15

Available Materials F-16

Plan of Construction

F-16

a. East Barrier

F-16

b. West Barrier

$F-16$

c. Tiverton Barrier F-16

$F-21$

Operation and Maintenance

F-16

a. East and West Barrier F-16

b. Tiverton Barrier F-17

$F-22$

Cost Estimates

$F-17$

Alternative Sites

$\mathrm{F}-17$

a. General

F -17

(1) South Street Barrier

F -17

(2) Fields Point Barrier

F -17

(3) Conimicut Point Barrier

F-18

(4) Middle Bay Barrier

F-18

(5) Sakonnet River Barriers

F -18 

APPENDIX G - PUBLIC HEARINGS

AND VIEWS OF OTHER AGENCIES

$\underline{\text { Paragraph }}$

Title

$\underline{\text { Page }}$

G-1

General

G-1

G-2

Digest of Public Hearings

G-1

G-3

Letter of Comment

G-1

a. Rhode Island Hurricane Survey Advisory Committee

G-1

G -4

Letters of Comment on Pollution

G-1

a. U.S. Public Health Service

G-1

b. Rhode Island Public Health Service

G-1

c. Massachusetts Department of Public Health

G-1

G-5

Letters of Comment by Fish and Wildlife Service

G-2

a. U.S. Fish and Wildlife Service G-2

b. Massachusetts Division of Marine Fisheries G-2

G-6 Local Cooperation

a. The Honorable Dennis J. Roberts, Governor, State of Rhode Island G-2

b. Governor, Commonwealth of Massachusetts $\mathrm{G}-2$

c. The Honorable Walter $\mathrm{H}$. Reynolds, Mayor of Providence G-2 

No.

Title

Page

A-1 History of Hurricane Tidal Flooding, Narragansett Bay Area

A-2 Summary of Other Notable Storms that Caused High Tides

B-1 Astronomical Tides, Narragansett Bay

B -2

B-2 Temperature and Salinity Observations by

Narragansett Marine Laboratory

$\mathrm{B}-4$

B-3 Tide Gages - Recording and Non-Recording

$\mathrm{B}-7$

B-4 Pertinent Data on Recent Hurricanes - Hurricanes since September 1938

B -12

B-5 Hurricanes or Severe Storms - Narragansett Bay Area

B -6

Elevation - Frequency Data - Hurricanes or Severe Storms at Providence, Rhode Island

B-7 Effect of Barriers on September 1938 Hurricane and Design Tidal Floods

B-8 Flushing Rates

B -30

C-1 Temperature and Precipitation at Providence, Rhode Island (1904-1954)

$\mathrm{C}-2$

C-2 Streamflow Data at U. S. G. S. Gaging Stations, Narragansett Bay Area 



\section{TABLES (Cont'd)}

No.

Title

$\underline{\text { Page }}$

D-1 Description of Damage Areas, Narragansett Bay D-4

D-2 Experienced 1954 Hurricane Tidal Flood Losses by Area and Type, Narrangasett Bay, Massachusetts - Rhode Island

D-5

D-3

Experienced 1954 Hurricane Tidal Flood Losses

by Town and Type, Narragansett Bay, Massachusetts - Rhode Island

D-6

D-4 Description of Damage Areas Used for Economic Analyses

D-5 Recurring Tidal Flood Losses - Major Hurricanes and Other Storms During Past 50 Years

Design Criteria and Selected Top Elevations $F-2$

$F-2$

Pertinent Data - Fox Point Barrier

$F-4$

F-3

Estimated First Costs for Fox Point Barrier

F-8

F-4

Estimated Annual Charges - Fox Point Barrier

$F-11$

$\mathbf{F}-5$

Estimated First Costs - Minimum Amount Lower Bay Barriers

F-6

Estimated Annual Charges - Minimum Amount Lower Bay Barriers

F-7 Estimated First Costs - Maximum Amount Lower Bay Barriers

F-8 Estimated Annual Charges - Maximum Amount Lower Bay Barriers 

Title

Tide Curves - Hurricane of 21 September 1938

Tide Curves - Hurricane of 14-15 September 1944

B -3

Tide Curves - Hurricane of 31 August 1954

B -4

Tidal Elevations at Providence

B-5

Frequency of Tidal Flooding from Hurricanes and Storms at Providence, Rhode Island

B-6

Hurricane Flood Levels - East shore of Narragansett Bay

B - 7

Hurricane Flood Levels - Sakonnet River, Mount Hope Bay, and Taunton River from Sakonnet Point to Dighton, Massachusetts

B -8

Effect of Proposed Plan on Design and 1938 Hurricane Tidal Elevations

Drainage Basin Map

$\mathrm{C}-2$

Isohyetal Map, Storm of September 17-22, 1938

C -3

Depth-duration Curve, Design Storm for Fox

Point Barrier

C-4 Depth-duration Curve, Design Storm for Lower Bay Barriers

C -5

Discharge Hydrographs from Transposed September 1938 Rainfall at Fox Point Barrier

C -6

Discharge Hydrographs from Transposed September 1938 Rainfall at Lower Bay Barriers 



\section{PLATES (Cont'd)}

No.

Title

$\mathrm{D}-1$

Data for Economic Analysis, Damage Zone 4b

$E-1$

Geology, South Street and Fox Point Sites

E-2

Geology, Fields Point Site

E-3

Geology, Conimicut Point to Nayatt Point Site

E-4

Geology, Middle Bay Site

E-5

Geology, Lower Bay-East Barrier Site, Sheet 1 of 3

E-6

Geology, Lower Bay-West Barrier Site, Sheet 2 of 3

E-7

Geology, Lower Bay-Tiverton Barrier Site, Sheet 3 of 3

$F-1$

Tidal Barrier Studies - General Plan 



\section{EXHIBITS}

No.

Title

To Accompany

B-1 Protection of Narragansett Bay from Hurricane Tides: Interim Report on Hydraulic Model Investigations

Appendix B 



\section{GLOSSARY}

HURRICANE SURGE: the mass of water causing an increase in elevation of the water surface above predicted astronomical tide at the time of a hurricane; it includes wind set-up; sometimes the maximum increase in elevation is referred to as the surge.

HURRICANE TIDE: the rise and fall of the water surface cring a hurricane, exclusive of wave action.

KNOT: a velocity equal to one nautical mile (6080.2 ft. ) per hour (about 1.15 statute miles per hour).

OVERTOPPING: that portion of the wave runup which goes over the top of a protective structure.

PONDING: the storage of water behind a dike or wall from local runoff and/or overtopping by waves.

POOL BUILDUP: the increase in elevation of water surface behind a structure due to runoff and/or overtopping by waves.

RUNUP: the rush of water up the face of a structure on the breaking of a wave. The height of runup is measured from the still-water level.

SIGNIFICANT WAVE: a statistical term denoting waves with the average height and period of the one-third highest waves of a given wave train.

SPRING TIDE: a tide that occurs at or near the time of new and full moon and which rises highest and falls lowest from the mean level.

STILL WATER LEVEL: the elevation of the water surface if all wave action were to cease.

STORM SURGE: same as "hurricane surge." 



\section{GLOSSARY (Cont'd)}

WAVE HEIGHT: the vertical distance between the crest and preceding trough.

WAVE TRAIN: a series of waves from the same direction.

WIND SET-UP: the vertical rise in the stillwater level on the leeward side of a body of water caused by wind stresses on the surface of the water.

BUILDUP BELOW BARRIER: the increase in water surface elevation in feet immediately downstream from the barriex resulting from construction of the barrier. 

APPENDIX A

HISTORY OF HURRICANE TIDAL FLOODING 

APPENDIX A

HISTORY OF FURRICANE TIDAL FLOODING

\section{A-1. HISTORICAL RESEARCH}

A review of historical records and newspaper files indicates that a number of hurricanes and cyclonic storms have reached the coast of southern New ingland with devastating force, while numerous other storms have passed so close that a slight change in meteorological conditions could nave resulted in severe damage. The records incicate tinat from 1635 to present the llarragansett Bay area has experienced or has been threatened by hurricane tidal flooding upon 63 occasions. The sreater number of these hurricanes, passing sorne distance away, dic not cause significant tidal flooding in the Narragansett Bay area, however they did present a potential threat of such floooing. Existing records indicate that the ten hurricanes which have created the most severe tidal flooding in the Narragansett Bay area are as follows, in the order of their estimated magnitude:

$\begin{array}{ll}\text { 1. August 3, 1638 } & \text { 6. December 10, 1878 } \\ \text { 2. August 15, 1635 } & \text { 7. October 30, 1866 } \\ \text { 3. September 21, 1938 } & \text { 8. September 8, 1869 } \\ \text { 4. August 31, 1954 } & \text { 9. October 23, 1878 } \\ \text { 5. September 23, 1815 } & \text { 10. September 14, 1944 }\end{array}$

The early hurricanes were not accompanied by so great a loss of life and property due to the lesser degree of development in the Narragansett Bay area. However, tidal flooding as described in records of the very earliest hurricanes appears to have been the greatest ever experienced in the bay area.

A-2. SUNMARY OF HURRICANE OCCURRENCES

A total of 63 hurricanes which are known to have either hit or narrowly missed the hhode Island coast is summarized in Table A-1. These hurricanes have been classified to indicate their magnitude in the Narragansett Bay area, as follows:

Type A - lĩajor tidal flooding

Type B - Moderate tidal flooding 
Type C - Threatened the area; path near Rhode Island coast (Scare).

In addition to the above hurricanes, there have been 31 other severe storms, not necessarily of tropical origin, that caused considerable damages (see Table A-2).

Of the 63 hurricanes listed in Table A-I, 12 are of type "A", 13 of type "B", and 38 of type "C". Thirty-nine of the 63 hurricanes have been recorded in the twentieth century as compared to 24 in the 266 years between 1635 and 1900 . However, this does not necessarily indicate a greater trend in hurricane activity, but rather a lack of records and information prior to 1900. It will be noted that 9 of the 24 early hurricanes caused severe damages in Rhode Island while only three of the 39 recent hurricanes can be considered as causing severe damages.

\section{A-3. DESCRIPTION}

A brief description of type "A" and "B" hurricanes experienced in the Narragansett Bay area, as reported in newspaper accounts, or obtained from other records, are given below.

a. 15 August 1635. Quoting from "History of Plymouth Plantation, 1620-1647," by William Bradford.

"This year the 14 or 15 of August (being Saturday) was such a mighty storm of wind and rain, as none living in these parts either English or Indian, ever saw, being like (for the time it continued) to those Hauric anes and Tuffons that writers make mention of in the Indies. It began in the morning, a little before day, and grew not by degrees, but came with violence in the beginning, to the great amazement of many. It blew dow sundry (21I). houses, and uncovered others; divers vessels were lost at sea, and many more in danger. It caused the sea to swell (to the southward of this place) above 20 feet, right up and down, and made many of the Indians to climb into trees for their safety; it took off the board roof of a house which belonged to this plantation at Manamet, and floated it to another place, the posts still standing in the ground; and if it had continued long without the shifting of the wind, it is like it would have drowned some part of the country. It blew down many huncred thousands of trees, turning up the stronger by the roots, and 
breaking the higher pine trees off in the middle, and the tall young oaks and walnut trees of good bigness were wound like a withe, very strange and fearful to behold. It began in the southeast and parted toward the south and east, and veered sundry ways; but the greatest force of it nere was from the former guarters. It continued not (in the extreme) above 5 or 6 hours, but the violence began to abate. The signs and marks of it will remain this 100 years in these parts where it was sorest. The moon suffered a great eclipse the second night after it."

The following excerpt is quoted from Governor John Winthrop's "Journal". 1630 to 1649:

"F* about to Northwest very strong, and, it being then about high water, by nine the tide was fallen about 3 feet. Then it began to flow again about one hour, and rose about 2 or 3 feet, which was conceived to be, that the sea was grown so high abroad with the Northeast wind, that, meeting with the ebb, it forced it back again.

"This tempest fwas not so far as Cape Sable, but to the south more violent, and made a double tide all that coast.

"The tide rose at Narragansett fourteen feet higher than ordinary and drowned 8 Indians flying from their wigwams."

b. 3 August 1638. From Governor John Winthrop's 'Journal", 1630 to 1649 .

"In the night was a very great temcest or hiracano at Southwest which drave a ship on ground at Charlestown, and brake down the vindmill there, and did much other demage. It flowed twice in 6 hours, and about Narragansett it raised the tide 14 or 15 feet above the ordinary spring tides, upright." 
c. 30 October 1723. From "The Boston Weekly News-Letter", No. 1033. From Thursday, November 27 to Thursday, November 14, 1723.

"Rhode Island - On wednesday last we had here a very great Southeast storm of wind and rain, and a very high tide, a foot higher than ever was known before, which has broken and carried away several of our wharves, and crove some vessels ashore from their anchors, and has done considerable damage in $w$ arehouses and cellars, to dry goods and other merchandise; the loss is computed to some thousand pounds.".

d. 24 October 176I. From "The Boston News Letter", No. 2991. Thursday, October 29, 1761.

"There was a hard gale of wind which brought the highest tide into the narbor of Providence in Rhode Island that hath been known in the memory of man, and carried away the great or Wieybosset Bridge. Five or six vessels were drove ashore and greatly damaged, and it being high water there, it got into the stores and cellars and damaged sugars, etc. to the amount of 12 or 15000 pounds their currency. On both roads East and west, so far as we have heard, the roofs of houses, tops of barns, and fences, have been blown down, and it is said thousands of trees have been torn up by the roots by the violence of the above storm, and we fear we shall hear melancholy accounts of damage done at sea."

The following excerpt is quoted from "Memoirs of Rhode Island 1636-1783" by Henry Bull.

"From the Newport Mercury of October 27, 1761 On Friday last came on a terrible storm from the Nortileast, which continued increasing with a very heavy rain, and did not abate till after 2 in the morning. The violence of the wind broke off part of the steeple of Trinity Church. Several persons sustained considerable loss in their sugar, salt, etc. by the prodigious rise of tide, which flowed into their stores and cellars. Many of the ships in the harbor were driven ashore from the wharves 
and their moorings, but without any considerable damage except to two ships. Sad havoc has been made with the lumber and wood on the wharves, great quantities of fence blown down and numbers of trees torn up by the roots. People hardly thought themselves safe in their own houses, for a more violent storm has scarce ever been known here."

e. 19-20 October 1770. From "listory of the State of Rhode Island" by Samuel Greene Arnold.

"A violent storm again blew down a part of the spire of trinity Church at Newport, and caused an immense loss of life and property along the coast. Newoort suffered very severely in this gale."

f. 23 September 1815. From "Historic Storms of New England" by Sidney Perley.

"The storm began at three o'clock on the morning of Friday, the twenty-second, when the wind was at the northeast, and rain fell copiously until sunrise. Shortly after, the clouds partly broke away, and fair weather seemed about to return. During the forenoon, however, the clouds became thicker, the sky darkened, and in some sections of New England rain fell to a considerable amount. In the afternoon the wind blew with increased force, and rain continued to fall in small quantities. Through the night the wind was noderate, and there was a slight fall of rain, but before sunrise next morning the wind again became violent having changed to the east in the night, and about nine o'clock it shifted to the southeast, and continued to increase in force until it blew so fiercely that buildings, fences, trees, vessels along the exposed sections of the coast, and all kinds of movable things, were swept away before it. But little rain fell during the tornado where it was the fiercest. The wind did not blow steadily, but came in gusts, and continued its work of destruction until noon, when it changed to the southwest, after which it quickly subsided. Then a little more rain fell, but before night pleasant weather had come. 
"The force of the gale was principally and most severely felt in Narragansett Bay in Rhode Island. The wind swept the bay and Providence suffered from its effectsmore than any other place. From ten to half-past eleven o'clock it blew a hurricane. About the wharves and lower part of the town generally confusion reigned. High water was about half-past eleven o'clock in the forenoon, and the wind brought in the tide ten or twelve feet above the /height of the usual spring tides, and seven and a half feet higher than ever known before, overflowing and inundating streets and wharves. The vessels there were driven from their moorings in the stream and fastenings at the wharves, with terrible impetuousity, toward the great bridge that connected the two parts of the town. The gigantic structure was swept away without/giving a moment's check to the vessels' progress, and they passed on to the head of the basin, not halting until they were high up on the bank. All the vessels were driven ashore, or totally destroyed. There were wrecked in the cove four ships, nine brigs, seven schooners and fifteen sloops. After the storm they lay high and dry, five or six feet above high-water mark, in the streets and gardens of the town. One sloop stood upright in Pleasant Street before the door of a $\mathrm{Mr}$. Webb, and a ship was in the garden of General Lippett. Nine of the vessels that were driven ashore were successfully launched again, but more than thirty were totally lost.

"The storm raged with increasing violence, and the water was rapidly rising and deluging the lower parts of the town. Wharves were being washed away, stores and other buildings on them were about to leave their foundations, and the water surged around the houses of the people who resided in the lower sections. Stores and dwelling houses were seen to reel and totter for a few moments, and then plunge into the deluge. A moment later their fragments were blended with the wrecks of vessels, some of which were on their sides, that were passing with great rapidity and irresistible impetuousity on the current to the head of the cove, to join the wrecks already on the land. 
"On the west side of the river the water rose nearly to the tops of the lower windows of the houses, and people were removing, in boats and scows, from their dangerous situation. Most of the stores and other buildings were destroyed and the fragments carried into the cove above the bridge. On the east side the water rushed impetuously through Weybosset Street, which was the principal thoroughfare, nearly a yard in depth, turbulently carrying along with it boats, masts, bales of cotton, etc., with almost resistless force. It seemed as if that portion of the town was doomed. The store on Bowen's wharf just below where the bridge had stood still maintained its place, though much injured, but all the stores below, on the east side, were either carried away or so much damaged that they were in a great measure useless. Several dwelling-houses on Eddy's point were carried off, leaving not a vestige behind. In Westminster Street, the water was from six to eight feet above the pavements. All the space which but an hour or two before had been occupied by valuable wharves and stores filled with goods, and the river that had been crowded with vessels, were now one wide waste of water raging and furious. Along the higher portion of land were heaped together lumber, wrecks of buildings and vessels of every description, carriages, and bales of cotton, mingled with household furniture, coffee, soap, candles, grain, flour and other kinds of merchandise.

"Five hundred buildings in all, large and small, were destroyed in this gale and flood, which, with other property that was lost, were valued at fifteen hundred thousand dollars.

"Beside those persons who were wounded and maimed, many valuable citizens were carried with their houses into the water, and others were crushed to death between the planks and the vessels as the latter dashed through the great bridge. No one knows how many human lives were lost in Providence, nor how many cattle were drowned. No business but that in connection with the storm could be done for some time, the streets having first to be cleared, and tinen buildings, bridges, and wharves rebuilt." 
"Bristol - At Bristol, a short distance from Providence down Narragansett Bay, all the vessels were driven a great distance in on the 1 and, and considerably injured. There the tide rose seven feet higher than it was ever known to rise before, and the wharves were completely swept away. A long row of brick stores on one of the wharves, with their contents, which were very valuable, were carried away. A great many trees were also blown down, and much other damage done."

g. 3 September 1821. From "The Newport Niercury", Newport, Rhode Island.

"Providence - During the severe gale on Mionday night, the Brig Cormerce got loose from her fastening at one of the wharves near the Market, and came with a tremendous crash against the bridge, slightly injuring some small craft which lay in her course, and the railing of the bridge. Considerable damage was done to trees, etc. in this vicinity by the gale; a part of Butts Rope Walk West Side, and an unfinished builaing at the North end, were blown down; the tower erected for the accommodation of: the wild beasts (our annual commencement visitors) in the yard of wessons Hotel, was also demolished but its inmates were secured from elopement.

"Much apprehension was entertained for several hours of disasters by filood as well as wind, and there were many waking eyes and throbbing hearts; but happily the tide and the residents within the range of the devastations by the never-to-be forgotten flood of 1815 retired to their beds about midnight, providently delivered from a visitation fearfully anticipated, and dreaded equally with fire brands, arrows and death. The tide did not rise much above its usual bounds."

Massachusetts.

h. 3 October 1847. From "The Daily Mercury", New Bedford,

"Severe northeasterly storm commenced here on Saturday night and continued on Sunday and yesterday with but little abatement. Some damage was done to the shipping and many chimneys were blown down. A large unfinished stone building was blown entirely down, and one or two small houses destroyed." 
i. 30 October 1866. From "The Providence Daily Journal", Providence, Khode Island.

"A gale of unwonted severity has prevailed in this vicinity since last evening. Shortly before 3:00 this morning rain commenced falling and continued until about noon. The wind has made much mischief with signs, awnings, chimneys, etc., and there has been some commotion among the vessels in the harbor.

"The heavy blow between 12:00 and 1:00 this afternoon did considerable damage to the shipping in the port, although the loss was not so serious as at one time seemed eminent.

"The gale stripped off part of the roof of the Stove Foundry on Cove Street. A building being constructed on Harrison Street was badly wrecked. Two dwelling houses on Smith's Hill belonging to Rhode Island Locomotive Works were prostrated and in falling crushed the side of the third building. These were ready for the plasters. The windows were not in.

"The tide was forced by the wind to an unprecedented height and the water flowed into West Water and Dyer Streets filling cellars and doing much damage. The water also overflowed the wharves on the east side and penetrated the cellars. Steam fire engines were brought into requisition to assist in abating the tide.

"Those malicious people who thought there was a leak somewhere about the ip 30,000 City Hall on Narket Square will not be surprised to learn that the flood tide found it and rushed in so freely that the water was several inches deep in the offices in the basement; there is grave reason to fear that the leak remains, against another flash time on the Narragansett. The gale at Narragansett pier was tremendous. The New St. Peters Free Chapel (Episcopal) was utterly demolished. Other buildings suffered." 
j. 8 Septenber 1869. From "The Great September Gale of 1869 in Providence and Vicinity" by Tillinghast and Mason of Providence.

"Our city has again been visited by a flood and gale, outrivaling in fury and destructiveness the terrible storm of September 1815. On Wednesday morning, September 8th, the sky was overcast, and occasionally a slight shower fell over the city; in the forenoon the clouds were dispelled somewhat and the sun came out for a short time. About noon the wind sprung up quite fresh from the southeast, blowing up large masses of dark clouds. Between two and three o'clock, p.m., it commenced to rain quite freely, the wind, in the meantime, blowing still heavier. At four p.m., the wind was blowing a perfect hurricane and the rain coming down in torrents. The combined power and fury of the elements were beyond all description. It seemed as if nothing could withstand them. The water in the harbor rose to a great height, and poured over the wharves and into the streets, in the lower portion of the city, .with appalling swiftness - at one time rising two feet in twenty minutes. Mighty trees bent and bowed before the tempest, some of them being torn up by the roots, while others were snapped off like rotten twigs. Boards, bricks, shingles, broken boughs, portions of gates and fences, shutters, signs, and fragments of all kinds filled the air. Massive buildings rocked like toys, roofs of tons in weight were lifted and carried rods away, or torn into minute pieces. Huge strips of tin and metal were torn from places where they had been securely nailed, and blown like sheets of paper, for long distances. Steeples rocked and fell; huge buildings were crushed in like egg shells; vessels were swept like chips upon the shore; dwellings were overturned and carriages blown along the street like feathers. For the first time since the advent of telegraphy in this city we were without a single' 'tap' from outside 'barbarians', not a wire of either the Western Union or Franklin Lines being in working order. If the violence of the wind had continued for half an hour longer, it is probable that the waters of the harbor would have united with those of the Cove, in the very busiest portions of the city. The rise was at the rate of a foot every 
ten minutes. The hurricane abated somewhat in its fury about 5:45; and very soon afterwards the water rapidily receded, leaving South water and Dyer Streets completely covered with the wrecks of the gale. The water poured into the Press Office in great volumes, putting out the fires in the engine room and submerging the press room to the depth of eighteen inches. An editorial in the Press of Thursday says: 'The water mark in the room where we write is eighteen inches from the floor and all around are indications of a great flood, beaten in history only by Noah's celebrated deluge and the Great Gale of 1815'.

"The Steam Fire Engines of the city were busy all night in pumping out the cellars near the wharves, but several days elapsed before the water was entirely cleared out.

Numbers of our citizens who experienced the gale of 1815, say the gale of 1869 was heavier while it lasted than that of its destructive predecessor. It is almost impossible to compute the damage done to property on land and sea, but in our own State it must amount to hundreds of thousands of dollars."

"Bristol - The gale Wednesday was very disastrous at this place. The wind was from the southeast and very terrific. The tide rose very rapidly. At $5 \frac{1}{2}$ o'clock it was six feet above high water mark. Had the wind held southeast two hours longer the damage by water would have been immense. Over two hundred of the ornamental trees which adorned the streets were blown down and others were destroyed. Host of the public buildings were more or less injured.

"A]l the wharves were damaged, some of them very seriously, especially the long wharf and the wharf belonging to the Fall River Iron Works Company. Nearly all of the sail boats, fishing boats and fishing smacks in the harbor, were either driven ashore and wrecked or sunk at their moorings. No lives were lost. Several persons were injured."

"Warren - A large number of valuable shade trees were uprooted in various parts of the tom. A portion of the new cotton factory was unroofed. 
"Throughout the state, but more especially along the coast, the damage by the gale was equally disastrous, and those who experienced it will not readily forget the September Gale of 1869."

k. 4-5 October 1877. From "The Evening Standard", New Bedford, Massachusetts.

"A severe storm of wind and rain commenced - last night and continued through the night and day. Some of the rain came in sheets, and the layers of sand which have washed down upon the lower streets attest the amount of rainfall.

"Limbs were broken off, fences blown down, walnuts and fruits blown from trees.

"More water than the drains could carry off ran from the Second. Street gutter into the Robeson Building. I Sycamore Street, between County and Sumer, is badly gullied, the gutter having been obstructed by a private bridge which turned the current into the middle of the street.

"The damage along the water front is insignificant as ample notice was given by old indications and preparations made for the storm. Several vessels in the harbor dragged their anchor. On the north side of Fish Island some spars and a scow got loose.

"Capt. Joseph C. Delano's gauge indicated a rainfall of 3.2 inches.

"The tide last evening was very high."

Excerpt from the "Boston Daily Globe", Boston, Massachusetts.

"Newport, R. I. - The storm was very severe in this vicinity last night, and blows a gale this morning. But few vessles are in the harbor. The Government schooner Joseph Henry drifted into Buntons Cove, and several yachts and boats were sunk." 
1. 23 October 1878. From "The Evening Standard", New Bedford, Massachusetts.

"The storm yesterday afternoon and last night was very severe, the rain falling in torrents, but there was little damage in this vicinity. Several vessels and boats got adrift at the docks, but trifling damage was done, some of the wharves were floocied. The last train from Providence was prevented from reaching $F$ all River on account of a washout near Cole's River. The velocity of the wind was 50 miles an hour. The storri originated in the Gulf of liexico on Monday morning."

m. 10 December 1878. From "The Providence Daily Journal", Providence, Rhode Island.

"Yesterday was a rainy day and the wind blew mightily from the southeast in fitful gusts. Toward evening the wind increased in fury and power. The wind did not decrease in volume or strength until 8:00 p.m. and the rain fell as rapidly as during the day.

"About 5:30 p.m. when the wind was at its height the cigar factory which was on supports preperatory to being moved was blown down ( $\$ 3,000$ damage). A floating bath house above India Bridge was blown from its mooring. A ship broke loose. Cellars flooded, some up to 8 inches.
"The water in the river (Providence River) rose very high, higher than before this year. Fortunately the wind went down about an hour before high water and danger was averted. This is the second time this year in which the gale ceased an hour or so before hizh tide. water washed over the Dorrance Street wharf. Dyrer Street cellars got a little water."

n. 24 August 1893. From "The Providence Daily Journal", Providence, Thode Island.

"The herald of the storm in this city was a heavy bank of mist, which caine in from the sea early in the evening. In the meantime the storm from the southeast cane rapidly along. It struck 
New York about 1:00 p.m. and the wind blew a gale. The disturbance was felt along the wires and shortly after 4:00 p.m. they ceased to act entirely along the line of the storm.

"st 11:00 p.m. the rain began to $\mathrm{fall}$ in the city. It was shortly before daybreak when the storm put in its appearance.

"At 5:00 a.m. the storm was in full possession of the tow and the rain fell in blinding sheets. The houses shook with the force of the blast. The big limbs were torn from the sturdy elms. The rain-fall practically ceased at 7:00 yesterday morning, with .55 inch being recorded at Hope Reservoir. A maximum velocity of 28 (?) m.p.h. was registered by the aerometer between the hours of $6: 00$ and 7:00 a.m. The greatest depth of rain for any one hour was .20 inch between 5:00 and $6: 00 \mathrm{a} \cdot \mathrm{m}$.

"At Pawtuxet when it was time for low tide yesterday morning, no low tide appeared. In fact it was said to be higher than usual."

o. 9 September 18,6. From "The Providence Daily Journal", Providence, Rhode Island.

"The storm which began yesterday morning, came unheralded, as all northeast storms do. The barometer had been falling since the night before. The wind increased in severity during the day and by noon was blowing a gale along the shore. In Providence the wind held steadily northeast and reached a maximum of $23 \mathrm{~m} \cdot \mathrm{p} \cdot \mathrm{h}$. This was probably much less fierce than was experienced in more level and exposed districts. This maximum was reached at the hour from 6:00 to 7:00 Thursday morning. Washouts occurred in many localities. liost of these were small and not productive of any great damage. The total rainfall as registered by the Hope Reservoir gauge was 3.16 inches. The greatest amount of rain falling in one hour was from $4: 50$ to $5: 50 \mathrm{p} \cdot \mathrm{m}$. Wednesday when .75 inch was recorded. For a portion of that hour rain fell at a rate of $1 \frac{1}{2}$ inch per hour but the torrents of 
rain were limited to something like half an hour, and during the remainder of the storm the rainfall was much lighter.

"The storm was a most peculiar one, for while the wind was off shore the sea was constantly increasing, and at nightfall it dashed in upon the rocky shore and the spray being thrown fully 25 feet in the air.

"Beach row, which lies along the ocean front, and is occupied by the Favillion, the batining house and a number of business offices was early in the evening partly submerged by water. At 9:00 last night the wind was blowing at the rate of $60 \mathrm{~m} \cdot \mathrm{p} \cdot \mathrm{h}$.

"At Block Island the storm was considered the severest on record at this season of the year. Late in the afternoon the wind velocity was recorded at $76 \mathrm{~m} . \mathrm{p} . \mathrm{h}$. wi.th no signs of abating.

"At Point Judith the wind reached 80 m.p.h. A number of vessels were lost."

p. 15 Sertember 1904. From "The Frovidence Journal", Frovidence, Rhode Island.

"One of the most memorable storms in the history of the city and certainly as long as the Weather Bureau has been running at City Hall broke yesterday morning about 7:00, and for intensity it has seldom been equalied. It was not long but was sudden and severe. The rainfall for the length of time was of a surprisingly large volume. The wind was about $50 \mathrm{~m} . \mathrm{p} . \mathrm{h}$., the temperature took a sudden fall after the storm and there were other phenomena connected with the storm.

"lelephone lines were blown down, trees uprooted, streets gullied out, cellars flooded and a large amount of stock in down town stores was seriously spoiled. Iittle damage was done to shipping as storm warnings had been put out. 
"About 6:30 a.m. the down pour and high wind came. Houses rocked. The streets on College HiIl had ditches washed out in the center 3 feet deep. The rainfall amounted to $l \overline{\bar{k}}$ inch for the hour between $7: 00$ and $8: 00 \mathrm{a} . \mathrm{m}$. The average force of the wind was $26 \mathrm{~m} . \mathrm{p} . \mathrm{h}$. but gusts reached $50 \mathrm{~m} \cdot \mathrm{p} . \mathrm{h}$. viany trees were destroyed or damaged. According to the City ingineer records at Providence the precipitation from the commencement of the storm 'was 3.78 inches; barometer 29.44.

"Block Island - The wind shifted to northwest and reached a velocity of $84 \mathrm{~m} \cdot \mathrm{p} . \mathrm{h}$. Several small boats went ashore on the breakwater.

"Newport was this week visited by a wind and rain storm which, for intensity and the amount of damage done, has not been equalled for many years. The gale was of comparatively brief duration but in a few hours it accomplished considerable damage. All day wednesday it was stormy with considerable rain and the storm continued during the night. About 6:00 l'hursday morning there was a decided change. The wind shifted suddenly from the southeast and commenced to blow with great fury. At the same time the rain continued to fall in large quantities. I'rees were uprooted, fences blown down, cellars flooded, etc."

q. 26 August 1924. From "The Providence Journal", Providence, Rhode Island.

"Lives were imperilled, vessels blown ashore in ivarragansett Bay, hundreds of trees uprooted or damaged, telephone and power service disrupted, and fruit, corn and other crops partially ruined yesterday in the severest summer wind and rainstorm that has visited Frovidence in many years. Damages totalling hundreds of thousands of dollars was caused.

"The northeaster, coming up the Atlantic coast from the tropics, hit Rhode Island with almost hurricane force, reaching a maximum of $50 \mathrm{m.p.h}$. at the Weather Bureau Station here, and raged along che Bay and coast territory at an estimated 75 to $80 \mathrm{~m} . \mathrm{p} . \mathrm{h}$. rate. Waves in sheltered Narragansett Bay were 
shipped to a height that mariners of 30 years experience say they have never seen equalled in these waters.

"The shores of the Bay are littered with small boats which were torn loose from their moorings by the wind and blown aground. 1:ore than 5,000 telephones in Rhode Island were fut out of commission and more trouble was experienced with power by the Narragansett Electric Lighting Company than in any storm except that of last ilarch in the history of the Comrany. liany sections were without lights last night.

"The wind raged throughout khode Lsland with tropical force from 11:00 in the morring until 2:00 in the afternoon. It was the third heaviest days rainfall in the history of the local weather bureau station. A total of 3.70 inches fell since the start of the storm londay and of this amount 2.76 inches fell yesterday.

"After raining almost continuously since shortly after 9:00 Monday evening, the storm subsided in mid-aftermoon yesterday and the skies cleared a few hours later. An abnormally low barometer reading of 29 was registered at the height of the storm. A $50 \mathrm{~m} \cdot \mathrm{p} \cdot \mathrm{h}$. velocity was registered from the North at 2:00. The wind shifted into the northwest a little later.

"Boats were broken up on rocks and sunk and cottages and stores along the shore at Narragansett Pier were flooded during the storm, which was accompanied by the worst surf experienced in years. Inland at Narragansett Fier, Feace Dale and wakefield the wind did heavy. damage to trees and shrubs on a number of estates,

"The tropical storm that was central south of Cace hatteras Monday night moved rapidly NorthNortheastward, and its center was off the eastern viaine coast Tuesday night. It was attended by strong shifting gales and general rains along the coast from the Carolines northward. The highest wind velocity reported was $72 \mathrm{~m} . \mathrm{p} . \mathrm{h}$. from northwest of Cape Latteras". 
r. 17 September 1933. From "The Providence Journal", Providence, Rhode Island.

"Drenched by heavy rain and swept by wind that reached gale proportions in many sections, Rhode Island took the shock of a raging storm yesterday aftermoon as it fassed by out at sea on a relentless course up the coast from the South Atlantic.

"As wind and wave subsided, after a day during which surf had founded hard along the entire shore line of the state, the damage was measured largely in terms of flooded streets and stripped trees, beached boats and weakened docks. Telephone service was disrupted in many places, transportation facilities were crippled, and many vacation homes of iight construction were fierced by the driving rain.

"After 4 days of wind and rain, climaxed by the gales of yesterday afternoon, Coast Guardsmen were able to relax their vigil. Town and city employees prepared to clear sand and gravel from the streets that had been flooded.

"The wind velocity reforted in Frovidence yesterday reached a maximum of $36 \mathrm{~m} . \mathrm{p} . \mathrm{h}$. at $3 \mathrm{p.m}$. , as compared to velocity of 52 and $50 \mathrm{~m} . \mathrm{p} . \mathrm{h}$. reported, respectively, at ivantucket island and Block island during the afternoon.

"From the time the rain began falling in Frovidence at $8: 30 \mathrm{a} . \mathrm{m}$. on Thursday until it ended at $6: 17$ last night, total precipitation was 4.34 (?) inches. The wind velocity ranged from 25 to $36 \mathrm{~m} . \mathrm{p} . \mathrm{h}$. during the day and dropped to 20 last night".

s. 19 Dectember 1936. From "The Frovidence Journal," Providence, Rhode Island.

"The worst coastal storm in years swept Rhode Island shores early today, as gales of near-hurricane force piled mountainous breakers on the beaches and torrential rain fell in increasing volume. 
"Virtually all shipping along the New England coast was in fort, but small craft in harbors were endangered by the high wind and the buffeting of the waves. All sailings from New England ports were cancelled last night.

"Gales estimated at 50 to $60 \mathrm{~m} \cdot \mathrm{p} \cdot \mathrm{h}$. were sweeping the south shore of the state last night as full gale warnings were ordered up from New Haven, Connecticut, to frovincetown.

"At watch Hill Coast Guard Station, the wind had reached $60 \mathrm{~m} . \mathrm{p} . \mathrm{h}$. at $1: 00$ this morning. The barometer had droffed to 29.4, a fall of 62 points since $8 \mathrm{a} . \mathrm{m}$. Surf was breaking over the sea wall on the Bay side near the watch Hill Yacht Club.

"Rain which had fallen in squalls during the day, began a steady downpour last night. A rainfall of 1.13 inch had fallen up to 9:00 last night in Providence, but the deluge after that hour was heavier than before.

"Summer cottages at south shore beaches were endangered by the high seas, which were reported to be the worst in recent years.

"At the Narragansett Coast Guard Station, waves washed across the beach and road to the station itself for the first time in 3 years.

"Spray from the surf at watch Hill, Newport and other points was hurled more than 40 feet high.

"In Providence, the wind had not exceeded a $26 \mathrm{~m} . \mathrm{p} \cdot \mathrm{h}$. velocity, excert in gusts, up to 10:00 last night, but unofficial reports indicated much higher wind later. Rain fell in heavy volume throughout the night.

"Surface water from last nights storm, which was up to the hub caps of autos, flooded a section of lineral Spring Avenue, Fawtucket, near Fower Road. 
"One of the most serious accidents caused by the storm was the breaking of a dam under construction at iymansville ilill in North rovidence, across the Woonascuatucket River, early yesterday. Although millions of gallons of water were released and a rond formed from Lymansville almost to Allendale, the waters receded sufficiently by noon to eliminate all danger of a flood.

"The highest wind velocity recorded during the storm was at Block Island where $64 \mathrm{~m} . \mathrm{F} \cdot \mathrm{h}$. was registered at $5 \mathrm{a.m}$. yesterday. In Frovidence the hignest wind velocity was $40 \mathrm{m.p} . \mathrm{h}_{\text {., }}$ and 3.99 inches of rain fell here during the storm."

t. 21 Sectember 1938. From "The Evening Bulletin", Providence, R. I.

"At least 125 persons died, many millions of dollars of property damage was wrought, and the normal life of thode island was completely crippled yesterday when a tropical hurricare swert the State, driving before it an incoming tide that piled the waters of Narragansett Bay 10 to 12 feet deer in downtown Frovidence.

"Standing directly in the path of the 76-milean-hour fury, this State of all the New ingland States bore the brunt of a swift and savage sweep that brought fantastic scenes beyond the wildest imagination to the old streets of Frovidence and to those towns particulariy that line the shores of the Bay.

"lien and women swam and drowned in water that flooded Irovidence from the foot of College Hill to $\mathrm{La} \mathrm{Salle} \mathrm{scuare,} \mathrm{water} \mathrm{trat} \mathrm{inas} \mathrm{lashed} \mathrm{to} \mathrm{white}$ caps by a wind that tore the roofs from business blocks and dwellings, that uprooted trees of great girth by the hundreds, and lifted coal barges out of the harbor and flung them into Fox Foint Square.

"It was and is the greatest disaster of any nature that ias ever befallen this State, and no 24-hour attempt can produce in its entirety a picture of the awful devastation of life and property. 
"At the moment, Rhode Island is crippled in its communications, its lighting, its transportation and much of its business.

"The town of westerly apparently suffered the greatest blow in the form of deaths. Twentynine fersons were known to have died, mostly from drowning, and 52 were known to be missing. In the town of Barrington twelve bodies were recovered. Five hundred were said to be homeless in Bay Srring and the summer colony of Annawamscutt in West Darrington was recorted wiped out. Two bodies were recovered at Sakonnet foint. At least five others are believed to have been lost there. Fifty cottages and summer shacks were swert away by waves which rose more than 20 feet over the breakwater. Two bodies were recovered at Somerset, Massachusetts. Three fersons were reported to have been drowmed, nine others were believed missing in East Frovidence.

"A span of Stone Bridge in Somerset, Massachusetts was swept out. White Church Bridge in Barrington collapsed. Reports were coming in from all over the state of bridges washed away and sections of highways completely destroyed.

"The high water mark on the old Chamber of Commerce building was almost three feet higher than the bronze line placed there to mark the spot where the water rose in 1815, the year of the 'big wind' when the harbor water was driven 11 feet nine and a ouarter inches above mean high water.

"Warnings that the tropical storm was on its way up the coast and was headed for the State began to indicate in the middle of the afternoon that this vicinity was in for a blow, but no one appeared to have any idea that the city was about to be literally torn ur by the roots in spots and that Narragansett Bay was to roll uf the streets of downtown Providence.

"There was an incoming tide yesterday afternoon, and the terrific wind pressure building up behind the rising waters literally began to drive Narragansett Bay into Providence harbor and then into the 
streets of the city. The flood was an unlooked for menace. INo one seemed to have thought about it.

NOTE: At Providence, Rhode Island on September 21, the tide rose to 15.7 feet above mean sea level. The maximum one minute sustained wind velocity was $95 \mathrm{mph}$ from the southwest, with a minimum barometer reading of 28.90 inches.

u. September 14-15, 1944. From "The Providence Journal", Providence, Rhode Island.

"From the time the rain started about 7:00 p.m. Thursday, there was a steadily rising storm tempo, with a few recessions that only saw the beat of the wind and rain come back with greater intensity until it was at its height. The Hillsgrove weather Bureau station registered a wind of 43 miles an hour with gusts of 49 miles an hour. At Newport the wind reached a velocity of 95 miles an hour at midnight. The waters did not reach the nigh mark of 1938 as the storm came at ebb tide. The high water mark in Providence was 8 feet. The rainfall in Providence measured 4.49 inches. Marine disasters have been estimated at approximately $\$ 37,000$ and property damages on Iand at \$129,000."

NOTE: At Providence, Rhode Island on September 14, the tide rose to 9.9 feet above mean sea level. The minimum barometer reading was 28.51 inches.

v. September'11, 1950. From "The Providence Journal", Providence, Rhode Island.

"Strong, drizzle-laden northeast winds lashed Rhode Isl and yesterday, ripped down electric and telephone lines, buffeted pleasure craft and fishing boats and kept the hurricane-conscious state anxious until nearly midnight.

"At 11:30 p.m. the Boston Weather Bureau said that the Atlantic hurricane, with winds up to 100 mph, was then located 80 miles south-southeast of Nantucket Island traveling in a north-northeasterly direction with a tendency to curve toward the north. 
"But the danger to Rhode Island disappeared with the heavy winds which passed at sea last night.

"Sakonnet Point reported the heaviest estimated blow last night when gusts there were estimated at $75 \mathrm{mph}$.

"Tides along the Rhode Island shore did not reach dangerous proportions as the seas were held back by the prevailing offshore northeast wind.

"But on Cape Cod 30 foot waves were kicked up by the roaring winds as the hurricane moved closer to that section.

"The highest wind velocity reforted by the weather station at the Hillsgrove Airfort at the storms height was only $34 \mathrm{mph}$, with gusts up to 50 mph. Rainfall during the damp, dismal day amounted to only 0.24 of an inch it was reported.

"The turbulent seas la shed by the heavy winds took a considerable toll of small craft in Rhode Island waters."

พ. August 31, 1954 (Carol). From "The Providence Journal", Providence, Rhode Island.

"The Hillsgrove Weather Bureau reported last night that winds roared steadily at 80 to $90 \mathrm{mph}$ during the storm with gusts up to $105 \mathrm{mph}$.

"As the storm center passed, tides thrust close to 1938 marks, carving great gashes out of the shoreline from westerly to Frovidence, pushing up breakers 35 to 40 feet high, and sending flood waters raging through the streets.

"By noontime, downtown Frovidence was under four or more feet of water.

"In some sections only low sand dunes remained to mark a once populous summer colony. 
"Hundreds of boats ranging from swall skiffs to Iuxurious power cruisers and sailboats were smashed to kindling wood.

"The fleet gathered at Galilee for the Atlantic Tuna Derby sustained major damage, with 40 exfensive boats sunk or damaged at their moorings in I'oint Judith Fond.

"Seawalls weighing thousands of tons were smashed to pebbles and thousands of trees, both inland and along the waterfront, were smashed to the ground.

"The pattern of the storm as observed by reporters at shore locations began to appear as early as $9: 30 \mathrm{a} \cdot \mathrm{m}$. When powerful easterly winds bore in on the coasts. By 10:30 a.m. tides had risen about 5 feet above normal and normally would have begun to ebb. The wind shifted to the southeast during the next hour and finally into the south and southwest.

"But the vater continued to climb higher, finally going 10 or 12 feet above its normal highest level.

"The highest water, which flooded into downtown Frovidence stores, rifping out hundreds of thousands of dollars in fixtures and merchandise and sending shorefront homes topkling over wavecut banks, actually came after the winds began to abate.

"Tide estimates in the warren and Barrington Rivers, placed the height of the water at from 10 to 15 feet above normal, where the waterfront picture of devastation was similar to that in the other shore communities.

"As water fron the Providence River, swollen by torrents from the skies, receded slowly it left the business district strewn with all imaginable kind of debris. 
"During the height of the storm, the flood in the Mall fronting City hall, measured to a depth of 4 feet.

"The critical point of yesterday's hurricane for northern and metropolitan Rhode Island fell within the half hour before noon, a time when the weather Bureau at Hillsgrove reforted a sustained wind velocity of $90 \mathrm{mph}$, with gusts uf to an estimated $115 \mathrm{mrh}$.

"A gust at 11:37 a.m. sent the anemometer needle off the register, indicating that wind velocity was more than $100 \mathrm{mph}$. The force was estimated at 110 to $115 \mathrm{mph}$.

"isetween $1: 30 \mathrm{a} . \mathrm{m}$. and $12: 30 \mathrm{p} . \mathrm{m}$. Hillsgrove reported the bureau barometer fell to a reading of 28.79 .

"Hurricane Carol developed off the coast of Jacksonville, Florida, * *

"Governor Roberts estimated damages at more than $200,000,000 . "$

NOTE: At Providence, Rhode Island on August 31, the tide rose to 14.7 feet above mean sea level. The minimum barometer reading was 28.79 inches.

x. 11 Sertember 1954 (Edna). From "The Providence Journal", Providence, ihode Island.

"winds of the seasons second hurricane in 11 days shifped into Provicence this forenoon with wirds of 55 miles per hour and gusts of 79 miles per hour, and a barometer reading of 28.56 shortly after noon.

"Solid advance reparations and a last minute split in the hurricane eye, which hit during the ebbing tide, left Providerce with comraratively minor damage. 
"As an added weather freak, rost all damage was caused by the late afternoon backlash when winds whirled to an unexfected reak velocity of 115 miles per hour at Newfort, Thode Island, after the center of the storm had rassed." 


\section{TABLE A-I}

HISTORY OF HURRICANE TIDAL FLOODING, NARRAGANSEIT BAY AREA

\begin{tabular}{|c|c|c|c|}
\hline Date of Hurricane & $\begin{array}{l}\text { Classifi- } \\
\text { cation (1) }\end{array}$ & $\begin{array}{l}\text { Foot } \\
\text { Notes }\end{array}$ & Remarks (2) \\
\hline 1635, Aug. 15 & A & & $\begin{array}{l}\text { "Tide at Narragansett } 14 \\
\text { ft. higher than ordinary; } \\
8 \text { Indians drowned." Hit } \\
\text { at high tide. }\end{array}$ \\
\hline 1638, Aug. 3 & A & & $\begin{array}{l}\text { "Tide flowed twice in } 6 \\
\text { hours about Narragansett } \\
\text { and rose } 14 \text { or } 15 \text { feet } \\
\text { above ordinary spring tide." } \\
\text { Probably highest tide ever } \\
\text { experienced. }\end{array}$ \\
\hline 1723, Oct. 30 & A & & $\begin{array}{l}\text { "Tide one foot higher than } \\
\text { ever known before." }\end{array}$ \\
\hline 1757, June 30 & C & (4) & $\begin{array}{l}\text { Atlantic coast hurricane, } \\
\text { Florida to Boston, Mass. }\end{array}$ \\
\hline 1761 , Oct. 24 & A & & $\begin{array}{l}\text { "Highest tide into the } \\
\text { harbor of Providence that } \\
\text { hath been known in the } \\
\text { memory of man." }\end{array}$ \\
\hline 1770 , Oct. 19-20 & B & & $\begin{array}{l}\text { "Immense loss of life and } \\
\text { property along the coast." }\end{array}$ \\
\hline 1773, August & c & (4) & $\begin{array}{l}\text { Passed near Boston, Mass. } \\
\text { No record of damage in } \\
\text { R. I. }\end{array}$ \\
\hline 1788, Aug. 12 & C & (4) & $\begin{array}{l}\text { Affected western New England; } \\
\text { much damage in Conn. and } \\
\text { Mass. }\end{array}$ \\
\hline 1804, Sept. 3-9 & C & (4) & $\begin{array}{l}\text { Severe storm; passed over } \\
\text { Cape Cod, missing northeast } \\
\text { (R. I.). }\end{array}$ \\
\hline
\end{tabular}




\section{TABLE A-I (cont'd)}

\begin{tabular}{|c|c|c|c|}
\hline Date of Hurricane & $\begin{array}{l}\text { Classifi- } \\
\text { cation (1) }\end{array}$ & $\begin{array}{l}\text { Foot } \\
\text { Notes }\end{array}$ & Remarks (2) \\
\hline 1804, Oct. 9-10 & C & (2) (4) & $\begin{array}{l}\text { "Most furious gale } \\
\text { experienced for many } \\
\text { years." (Newport } \\
\text { Mercury, Newport, R.I.) }\end{array}$ \\
\hline 1815, Sept. 23 & A & & $\begin{array}{l}\text { Tide rose } 11.8 \mathrm{ft} \text {. } \\
\text { above mean high tide } \\
\text { in Providence on } \\
\text { Sept. 23. (1!.2 m.5.1.) }\end{array}$ \\
\hline 1821, Sept. 3 & B & & $\begin{array}{l}\text { "Considerable damage } \\
\text { was done to trees, etc. } \\
\text {---". Greatest in- } \\
\text { tensity felt at New } \\
\text { York where tide rose } 13 \\
\text { feet in one hour. From } \\
\text { Long Island, center passed } \\
\text { inland on Sept. } 3 \text {. }\end{array}$ \\
\hline 1829, July 24 & C & (4) & $\begin{array}{l}\text { Reported to have been } \\
\text { felt in Boston, Mass.; } \\
\text { no accounts of damage } \\
\text { in R. I. }\end{array}$ \\
\hline 1841 , Oct. 3 & B & & $\begin{array}{l}\text { "Some danage was done } \\
\text { to the shipping and many } \\
\text { chimneys were blown down." }\end{array}$ \\
\hline 1854, Sept. 10-11 & C & (4) & $\begin{array}{l}\text { Severe in Southern States; } \\
\text { passed over New England } \\
\text { near Eoston. }\end{array}$ \\
\hline 1865, Oct. 30 & A & & $\begin{array}{l}\text { "The tide was forced by } \\
\text { the wind to an unprece- } \\
\text { dented height----doing } \\
\text { much damars. "The water } \\
\text { also overilowed the } \\
\text { wharves on the east } \\
\text { side-.--". }\end{array}$ \\
\hline
\end{tabular}


TABLE A-I (cont'd)

\begin{tabular}{|c|c|c|c|}
\hline Date of Iurricane & $\begin{array}{l}\text { Classifi- } \\
\text { cation (1) }\end{array}$ & $\begin{array}{l}\text { Foot } \\
\text { Notes } \\
\end{array}$ & Reinarks (2) \\
\hline 1869, Sept. 8 & $A$ & & $\begin{array}{l}\text { Described as "The Great } \\
\text { Sept. Gale of } 1869 . " \\
\text { Tide rose } 6.2 \text { feet above } \\
\text { mean high tide in Provi- } \\
\text { dence on Sept. } 8 \text {. ( } 8.6 \text { m.s.I }\end{array}$ \\
\hline 1877 , Oct. 4-5 & B & & $\begin{array}{l}\text { "Severe storm of wind } \\
\text { and rain--.. The tide } \\
\text { Iast evening was very } \\
\text { high. Several yachts } \\
\text { and boats were sunk." } \\
\text { (Newport, R. I.) }\end{array}$ \\
\hline I878, Oct. 23 & A & & $\begin{array}{l}\text { "Severe storm----rain } \\
\text { falling in torrents. } \\
\text { Some of the wharves } \\
\text { were flooded." }\end{array}$ \\
\hline 1878, Dec. 10 & A & & $\begin{array}{l}\text { "water in river rose } \\
\text { very high---. Wind } \\
\text { went down about an hour } \\
\text { before high water." }\end{array}$ \\
\hline 1879, Aug. 16-20 & C & (4) & $\begin{array}{l}\text { Path followed up coast, } \\
\text { passed over Cape Cod; } \\
\text { no account of damage. }\end{array}$ \\
\hline 1889, Sept. 10 & C & (2) (4) & $\begin{array}{l}\text { Accounts of high tides } \\
\text { at Newport, R. I. }\end{array}$ \\
\hline 1893, Aug. 24 & B & (2) (4) & $\begin{array}{l}\text { "Storm struck N. Y. and } \\
\text { moved rapidly along to } \\
\text { Providence. Rain fell } \\
\text { in blinding sheets. } \\
\text { Houses shook with the } \\
\text { force of the blast." } \\
\text { Tide rose } 3 \text { ft. above } \\
\text { mean high water at } \\
\text { Providence. ( } 5.4 \text { m.s.l.) }\end{array}$ \\
\hline
\end{tabular}


$\underline{T \Lambda B L E A-1}$ (cont'd)

\begin{tabular}{|c|c|c|c|}
\hline Date of Hurricane & $\begin{array}{l}\text { Classifi- } \\
\text { cation (1) }\end{array}$ & $\begin{array}{l}\text { Foot } \\
\text { Notes } \\
\end{array}$ & Remarks (2) \\
\hline 1896, Sept. 9-10 & B & & $\begin{array}{l}\text { "At Block Island the } \\
\text { storrn was considered } \\
\text { the severest on record } \\
\text { at this season of the } \\
\text { year. Hurricane had } \\
\text { much of its force at } \\
\text { sea, struck the coast } \\
\text { east of New York City, } \\
\text { passed over a track of } \\
\text { territory to the south } \\
\text { of Boston and went off } \\
\text { to sea again." }\end{array}$ \\
\hline 1901, Sept. 9-19 & C & $(3)(4)$ & $\begin{array}{l}\text { Passed south and east } \\
\text { of Cape Cod, travelling } \\
\text { in a northeasterly } \\
\text { direction. }\end{array}$ \\
\hline 1902, June 11-20 & C & (3) $(4)$ & $\begin{array}{l}\text { Path crossed Buzzards } \\
\text { Bay and Cape Cod, moving } \\
\text { northeast; no accounts } \\
\text { of damage. }\end{array}$ \\
\hline 1902, June 29 & C & (4) & $\begin{array}{l}\text { Center passed over Conn. } \\
\text { and southern Rhode Island, } \\
\text { travelling southeast; no } \\
\text { account of damages. }\end{array}$ \\
\hline 1902, Oct. 7-13 & c & (3) (4) & $\begin{array}{l}\text { Passed along path south } \\
\text { of Long IsIand and } \\
\text { Nantucket moving east. }\end{array}$ \\
\hline 1903, Sept. 16 & C & (2) (4) & $\begin{array}{l}\text { "----the Storm which } \\
\text { caused so much damage } \\
\text { in other parts of New } \\
\text { England must have spent } \\
\text { its force before reach- } \\
\text { ing this city." (Provi- } \\
\text { dence Daily Journal, } \\
\text { Providence, R. I.) }\end{array}$ \\
\hline
\end{tabular}


TABIE A-1 (cont'd)

\begin{tabular}{|c|c|c|c|}
\hline Date of Hurricane & $\begin{array}{l}\text { Classifi- } \\
\text { cation (I) }\end{array}$ & $\begin{array}{l}\text { Foot } \\
\text { Notes }\end{array}$ & Remarks (2) \\
\hline 1904, March 9-14 & C & (3) (4) & $\begin{array}{l}\text { Passed south of Nantucket } \\
\text { moving northeast. }\end{array}$ \\
\hline 1904, Sept. 15 & B & & $\begin{array}{l}\text { "One of the most memorable } \\
\text { storms - , and for in- } \\
\text { tensity it has seldom been } \\
\text { equalled. Telephone lines } \\
\text { were blown down, trees } \\
\text { uprooted, streets gutted, } \\
\text { cellars flooded and a } \\
\text { large amount of stock in } \\
\text { dow town stores was } \\
\text { seriously spoiled." } \\
\text { (Providence) }\end{array}$ \\
\hline 1911, Aug . 24-30 & C & (4) & $\begin{array}{l}\text { Passed south of Cape Cod; } \\
\text { no accounts of local } \\
\text { damage. }\end{array}$ \\
\hline 1912, Sept. 11-23 & C & (4) & $\begin{array}{l}\text { Passed near New Bedford, } \\
\text { Mass.; followed easterly } \\
\text { path across southern New } \\
\text { England. }\end{array}$ \\
\hline 1916, Juzy 21 & C & $(2)(4)$ & $\begin{array}{l}\text { Passed over Providence } \\
\text { and south of Boston, } \\
\text { Mass. "all along the } \\
\text { southern coast (Rhode } \\
\text { Island) and around } \\
\text { Point Judith the heavy } \\
\text { surf and breakers are } \\
\text { playing sad havoc with } \\
\text { the traps of the fisher- } \\
\text { men and lobstermen." }\end{array}$ \\
\hline 1920, Oct. 1 & C & (3) (4) & $\begin{array}{l}\text { Storm passed just west } \\
\text { of New York heading north. }\end{array}$ \\
\hline 1923, Oct. 14-19 & C & (3) (4) & $\begin{array}{l}\text { Passed near Boston moving } \\
\text { northwest. Storm of } \\
\text { slight energy. }\end{array}$ \\
\hline
\end{tabular}


IABLE A-I (cont'c)

\begin{tabular}{|c|c|c|c|}
\hline Date of Hurricane & $\begin{array}{l}\text { Classifi- } \\
\text { cation (1) }\end{array}$ & $\begin{array}{l}\text { Foot } \\
\text { Notes } \\
\end{array}$ & Remarks (2) \\
\hline 1924, Aug. 26 & B & . & $\begin{array}{l}\text { "Heavy rainfall; lives } \\
\text { were imperilled, bay } \\
\text { littered with sinall } \\
\text { boats, trees uprooted, } \\
\text { telephone and power } \\
\text { service disrupted, and } \\
\text { crops partially ruined." }\end{array}$ \\
\hline 1929, Oct. 3 & C & $(3)(4)$ & $\begin{array}{l}\text { Moved northeast passing } \\
\text { over eastern liev York } \\
\text { state and northwestern } \\
\text { Vermont. }\end{array}$ \\
\hline 1933, Sept. 16-17 & B & & $\begin{array}{l}\text { "Rhode Island took the } \\
\text { shock of a raging storm } \\
\text { as it passed by out at } \\
\text { sea. Streets were } \\
\text { flooded, trees stripped, } \\
\text { boats beached, docks } \\
\text { weakened, telephone } \\
\text { service disrupted and } \\
\text { transportation facili- } \\
\text { ties crippled." }\end{array}$ \\
\hline 1934, June 4-21 & $-\mathrm{C}$ & (4) & $\begin{array}{l}\text { Travelled overland from } \\
\text { Louisiana; crossed over } \\
\text { Long Island and Cape } \\
\text { Cod moving northeast. }\end{array}$ \\
\hline 1934, Sept. 9 & $\mathrm{C}$ & (3) (4) & $\begin{array}{l}\text { Track across Connecticut, } \\
\text { east of Bridgeport. } \\
\text { "Damage in Providence } \\
\text { was extensive, trees up- } \\
\text { rooted, electric poles } \\
\text { levelled and shipping } \\
\text { in Narragansett Bay } \\
\text { paralyzed." }\end{array}$ \\
\hline
\end{tabular}




\section{TABLE A-1 (cont'd)}

\begin{tabular}{|c|c|c|c|}
\hline Date of Hurricane & $\begin{array}{l}\text { Classifi- } \\
\text { cation (1) }\end{array}$ & $\begin{array}{l}\text { Foot } \\
\text { Notes } \\
\end{array}$ & Remarks (2) \\
\hline 1936, Sept. 19 & B & & $\begin{array}{l}\text { "Worst coastal storm } \\
\text { in years swept Rhode } \\
\text { Island shores; tor- } \\
\text { rential rainf all and } \\
\text { gale winds." Greatest } \\
\text { intensity felt at New } \\
\text { York. }\end{array}$ \\
\hline 1938, Sept. 21 & A & & $\begin{array}{l}\text { At Providence the tide } \\
\text { rose to } 15.7 \text { feet above } \\
\text { mean sea level. Record } \\
\text { flood of recent times. } \\
\text { "It was and is the } \\
\text { greatest disaster of } \\
\text { any nature that has } \\
\text { ever befallen this State." } \\
\text { (R. I.) }\end{array}$ \\
\hline 1940, Sept. 2-3 & C & (3) & $\begin{array}{l}\text { This hurricane passed by } \\
\text { at sea South of Nantucket. }\end{array}$ \\
\hline 1940, Sept. 11-18 & C & (3) (4) & $\begin{array}{l}\text { Followed northeasterly } \\
\text { path east of Cape Cod. }\end{array}$ \\
\hline 1943, Oct. 17 & C & (3) (4) & $\begin{array}{l}\text { Passed east of Cape Cod, } \\
\text { moving due north. }\end{array}$ \\
\hline 1944, Aug. 3-4 & C & (3) (4) & $\begin{array}{l}\text { Moved northeasterly, } \\
\text { along path south of Iong } \\
\text { Island and Nantucket. }\end{array}$ \\
\hline 1944, Sept. I4 & A & & $\begin{array}{l}\text { At Providence the tide } \\
\text { rose to } 9.9 \mathrm{ft} \text {. above } \\
\text { mean sea level. "Storm } \\
\text { came at ebb tide." Trees } \\
\text { were uprooted, telephone } \\
\text { and electric lines were } \\
\text { blown down, pavements } \\
\text { ripped up and buildings } \\
\text { flooded. }\end{array}$ \\
\hline
\end{tabular}




\begin{tabular}{|c|c|c|c|}
\hline Date of Hurricane & $\begin{array}{l}\text { Classifi- } \\
\text { cation (1) }\end{array}$ & $\begin{array}{l}\text { Foot } \\
\text { Notes } \\
\end{array}$ & Remarks (2) \\
\hline 1944, Oct. 21 & C & (3) (4) & $\begin{array}{l}\text { Path crossed over } \\
\text { Nantucket and easterly } \\
\text { tip of Cape Cod. }\end{array}$ \\
\hline 1945, June 26 & C & (2)(3) & $\begin{array}{l}\text { "Torrential rain and } \\
\text { gale force winds put } \\
\text { power and telephone } \\
\text { lines out of commission, } \\
\text { flooded streets and } \\
\text { damaged trees and crops." } \\
\text { (Providence Journal, } \\
\text { Provicence, R. I.) }\end{array}$ \\
\hline 1945, Sept. 19 & C & (4). & $\begin{array}{l}\text { Overland from Florida; } \\
\text { passed just west of } \\
\text { New York moving north- } \\
\text { east. }\end{array}$ \\
\hline 1949, Aug. 29 & C & (3) (4) & $\begin{array}{l}\text { Travelled overland from } \\
\text { northern Florida, crossed } \\
\text { center of viaine. }\end{array}$ \\
\hline 1950, Aug. 20 & C & (2) (3) & $\begin{array}{l}\text { "Hurricane passed about } \\
200 \text { miles seaward. Tor- } \\
\text { rential rains.flooded } \\
\text { the streets of Providence } \\
\text { heavy seas pounded the } \\
\text { coast." (Providence Jour- } \\
\text { nal) }\end{array}$ \\
\hline 1950, Sept. 11 & B & & $\begin{array}{l}\text { Tide rose to } 4.1 \text { ft. } \\
\text { above mean sea level at } \\
\text { Newort and estimated } \\
\text { at } 6.4 \text { ft. above mean } \\
\text { sea level at Providence } \\
\text { "Tides along ihode } \\
\text { Island shore were held } \\
\text { back by prevailing off- } \\
\text { shore wind. Hurricane } \\
\text { passed at sea." }\end{array}$ \\
\hline
\end{tabular}




\begin{tabular}{|c|c|c|c|}
\hline Date of Hurricane & $\begin{array}{l}\text { Classifi- } \\
\text { cation (1) }\end{array}$ & $\begin{array}{l}\text { Foot } \\
\text { Notes } \\
\end{array}$ & Remarks (2) \\
\hline $\begin{array}{l}\text { 1952, Sept. I } \\
\text { ("Able") }\end{array}$ & C & (2)(3) & $\begin{array}{l}\text { Followed northe asterly } \\
\text { track; passed approxi- } \\
\text { mately over New York. }\end{array}$ \\
\hline 1953, Aug. 15 & C & (2) (3) & $\begin{array}{l}\text { Followed path south of } \\
\text { Long Island and Nan- } \\
\text { tucket. }\end{array}$ \\
\hline 1953, Sept. 7 & C & (2) (3) & $\begin{array}{l}\text { Passed east of Cape Cod, } \\
\text { heading generally north. }\end{array}$ \\
\hline $\begin{array}{l}\text { 1954, Aug: } 31 \\
\text { ("Carol") }\end{array}$ & A & . & $\begin{array}{l}\text { One of the greatest hurri- } \\
\text { canes in recent years. } \\
\text { Exceeded only by Septerber } \\
1938 \text { hurricane. Probably } \\
\text { fourth highest tide in } \\
\text { history of Providence. }\end{array}$ \\
\hline $\begin{array}{l}\text { 1954, Sept. } 11 \\
\text { ("Edna") }\end{array}$ & B & & $\begin{array}{l}\text { At Providence the tide } \\
\text { rose to } 5.5 \text { feet above } \\
\text { mean sea level. This was } \\
\text { the second hurricane in } \\
11 \text { days. Hurricane eye } \\
\text { split prior to reaching } \\
\text { Rhode Island coast. }\end{array}$ \\
\hline $\begin{array}{l}\text { 1954, Oct. } 15 \\
\text { ("Hazel") }\end{array}$ & B & & $\begin{array}{l}\text { Brought torrential rain- } \\
\text { fall and river flooding } \\
\text { to interior of Connecticut, } \\
\text { Massacinusetts and Rhode } \\
\text { Island; negligible tidal } \\
\text { flooding in southern New } \\
\text { England. }\end{array}$ \\
\hline $\begin{array}{l}\text { 1955, Aug. 5-13 } \\
\text { ("Connie") }\end{array}$ & C & (2) (3) & $\begin{array}{l}\text { At Providence the tide } \\
\text { rose to } 5.9 \text { feet above } \\
\text { mean sea level. }\end{array}$ \\
\hline $\begin{array}{l}\text { 1955, Aug; 10-19 } \\
\text { ("Diane") }\end{array}$ & $\mathrm{C}$ & $(2)(3)$ & $\begin{array}{l}\text { At Providence the tide } \\
\text { rose to } 3.9 \text { feet above } \\
\text { mean sea level. Brought } \\
\text { record rainfali to many } \\
\text { areas of INew England. }\end{array}$ \\
\hline
\end{tabular}


TABLE A-I (cont'd)

\section{Classifi- Foot}

Date of Hurricane

1955, Sept. 11-21

("Ione") cation (1) Notes

C

(2) (3)
Remarks (2)

At Providence the tide rose to $2.7 \mathrm{ft}$. above mean sea level.

Notes

(1) Classifications indicating magnitude of hurricane in the Narrazansett $\mathrm{B}$ ait area:

1 - Inajor ridal Floocing

$B$ - Nocierate I'idal Flooding

C - Threatened the Area; Path near Rhode Island Coast (Scare)

(2) Local newspaver accounts, histories, etc. See paragraph 1-3 for jistorical abstracts of "lype " $A$ " and "B" storms.

(3) iraterial Iurnisined by U. S. Tivather Bureau.

(4) "Hurric anes - Iheir Nature and History" by I. R. Tanuenill (1956). 


\section{TABLE A-2}

SUMMARY OF OTIER NOTABLE STORIS THAT CAUSED HIGH TIDES

Date of Storm

1723, Feb. 24

1751, Jan. 22

1778, Aug. 12

1869, Feb. 8

1879, July. 16

1886, Feb. 11

1888, July $11-12$

1893, Aug. 20

\section{Remarks}

"Northeast storm of wind and rain, broke and carried away several wharfs; highest tide in 19 years." (Historic Storms of New England by Sidney Perley)

"A great gale occurred during which an abundance of buildings were blown down in warren and Beecher's Cove." (200th Anniversary of Warren, R. I. in ilistorical Sketch and Program in 17471947)

"Heavy rain all night and day, with strong gale at northeast ... one of the most violent gales on record" (Newport). (History of the State of Rhode Island by Samuel Amold Greene)

"The heaviest in our city (New Bedford) since the gale of 1815 and much damage was done. The rapid rise of the tide brought the vessels up nearly to a level with the wharves." (Daily Mercury, New Bedford, Mass.)

"There came on a very heavy severe tempest, with the thunder, hale, wind, and a very heavy rain, SE 700" (ivewport). (weather Diary of Zenas Hammond, Newfort, R. I.)

"Very heavy rain ... There was 5 or 6 feet of water in most of the cellars on Cedar Grove Street. The cord at the wamsutta mills overflowed and flooded cellars on that part of Logan Street adjoining" (New Bedford). (Providence Journal, Providence, K. I.)

"Storm became ouite severe; all over the city (Providence) there is evidence of its violence; washouts exceed those of any storm since the great Sertember Gale of 1869." (The Boston Daily Globe)

"Trees were blown down, telephore and trolley wires were down. One ship lay broadside on rocks ..." (rrovidence Daily Journal) 


\section{$\underline{\text { TABLE } A-2}$ (cont'd)}

Date of Storm

1895, Feb. 7

1933, Jan. 27

1936, Oct. 1

1542, Narch 3

*1943, Irarch

* 1944 , November

$* 1945$, November

*1947, Plarch

*1947, October

*1947, November

194?, Oct. 22

1950, Aug. 1

\section{Remarks}

"The tide rose to an unprecedented height and but for the fact that the harbor was completely frozen over, .... Damage would have been incalculable. Every wharf was submerged" (New Bedford). (Evening Standard, New Bedford, ilass.)

Tide estimated at 7.1 feet above mean sea level at Providence.

At Providence the tide was estimated to be 6.6 feet above mean sea level.

At Providence the tide was estimated to be 6.4 feet above mean sea level.

Tide rose to 5.5 feet above mean sea level at Providence.

Tide rose to 6.2 feet above mean sea level at Providence.

Tide rose to 6.1 feet above mean sea level at Providence.

Tide rose to 5.0 feet above mean sea level and estimated at 7.6 feet above mean sea level at Providence.

Tide rose to 6.8 feet above mean sea level at Providence.

Tide estirnated at 7.3 feet above mean sea level at Providence.

At Providence the tide was estimated to be 6.8 feet above mean sea level.

"Streets were flooded in sections of Providence and nearby cities to deptins up to 3 feet. The storm center was roushly northeast southwest and communities in that path received torrential riins which caused severe damage in many cases." (Providence Journal) 


\section{TABLE A-2 (cont'd)}

Date of Storm

1950, Nov. 25-26

1950, Dec. 8

1951, Feb. 7

1951, Nov. 7

1952, Narch 11

*1953, February

*1953, April

*1953, October

1953, Nov. 7 $\underline{\text { Remarks }}$

At Providence the tide rose to 6.8 feet above mean sea level. Storm struck New York the severest blow. Weather observers in Rhode Island described the storm as "the worst gale since the 1944 hurricane."

At Providence the tide rose to 6.2 feet above mean sea level.

At Newort the tide rose to 4.7 feet above mean sea level and estimated at 7.2 feet above mean sea level at. Providence.

At Providence the tide rose to 5.1 feet above mean sea level.

At Providence the tide rose to 2.6 feet above mean sea level.

Tide estimated at 6.9 feet above mean sea level at Providence.

Tide estimated at 6.6 feet above mean sea level at Providence.

Tide estimated at 6.8 feet above mean sea level at Providence.

At Newport the tide rose to 5.2 feet above mean sea level and estimated at 7.9 feet above mean sea level at Providence.

*From monthly maxima recorded at USGS gage 



\section{APPENDIX B}

HURRICANE SURGES AND TIDAL HYDRAULICS 


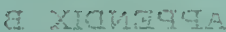

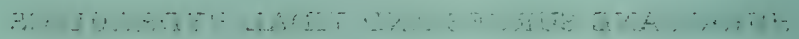




\section{APPENDIX B}

HURRICANE SURGES AND TIDAL HYDRAULICS

NORMAL CONDITIONS IN NARRAGANSETT BAY

\section{B-1. GENERAL}

Narragansett Bay reaches inland about 26 miles in a northerly direction from the ocean to Provldence, and has a water area, including Mount Hope Bay and the Sakonnet River, of approximately $I_{4} 0$ square miles. The width of the bay across the mouths of the East and West Passages is 4 miles, and across the mouth of the Sakonnet River at Sachuest Point, slightly orer 2.5 miles. The widest stretch of the bay is just south of Prudence Island where there is close to 6 miles of open water. Depths range fran 50 feet in the lower West Passage, 160 feet in the East Hassage, and 50 leet at the mouth of the Sakonnet River to shallow and shoal water in the innumerable small inlets and indentations in the Upper Bay. South of Narragansett Bay is Rhode Island Sound and the Atlantic Ocean, with Block Island and Long Island to the west and Buzzards Bay and the El1zabeth Islands to the east. Approximately 90 miles outside the bay lies the edge of the Continental Shelf where the water drops in depth from 600 feet to 3,000 feet in about 12 miles.

\section{B-2. ASTRONOMICAL TIDES}

Two high and two low tides occur each lunar day in Narragansett Bay, with the time between high and low tide varying from 4 hours and 41 minutes to 7 hours and 47 minutes and averaging about 6 hours and 12 minutes. The greatest variations exist with the occurrence of spring tides, which prevall with the full and new moons. The mean tidal range, between mean low and mean high water, is 3.5 feet at Newport, 4.6 feet at Providence and 4.4 feet at Fall River. The time lag of the mean high tide between Newport and Providence is about 10 minutes. Tidal data for these two locations are surmarized in Table B-1.

\section{B-3. FACTORS INFLUENCING GRAVITATIONAL TIDES}

The predicted tides in Narragansett Bay are subject to numerous meteorological influences such as changes in atmospherlo pressure and strong winds, besides the normal gravitational effects of the 
sun and the moon. On the North Atlantic coast, it is generally assumed that a drop in barometric pressure of one inch (of mercury) vill cause about a one-foot rise in water level. Normal winds within the bay have little effect on the tide levels, but do have noticeable influence on timing. However, during a strong coastal storm, such as a northeaster, tide levels often build up one to two feet above the predicted elevations. When a severe storn occurs over Narragansett Bay, with colncident low pressure and strong southerly winds, the observed tide far exceeds predicted elevations. Tidal data are given for 15 locations in the Narragansett Bay area in the yearly tide table publication of the $0 . S$. Department of Cammerce, Cosst and Geodetic Survey entitled "Tide Tables, East Coast, North and South America."

\section{TABLE B-1 \\ ASTRONOMICAL TIDES NARRAGANSETT BAT}

Mean Range (ft.)

Mean Low Water (below m.8.1.)

Hean High Water (above m.s.1.) Average Spring Tide Range ( $f t_{0}$ ) Maxdmum Spring Tide (above m.s.1.) Minimum Low Water (below $\mathrm{m}, \mathrm{s.1.}$ )
Newport Providence Fall River

$\begin{array}{lll}3.5 & 4.6 & 4.4 \\ 1.6 & 2.2 & 2.1 \\ 1.9 & 2.4 & 2.3 \\ 4.4 & 5.7 & 5.5 \\ 3.3 & 3.9 & 3.8 \\ 4.1 & 5.2 & 5.1\end{array}$

B-4. CURRENTS

Normal tidal current velocities over the greater part of Narragensett Bay vary from zero, at slack water, to about 1.5 knots. Velocities between 1 and 1.5 knots occur at the bridges in the Seekonk River, and velocities of more than 2.8 knots are experienced at the highway bridge across the Sakonnet River. Current velocities during spring tide will often exceed the normal velocities by 20 percent. Currents close to the surface, however, show $a$ wide variation when influenced by strong winds. For example, high winds from the northwest will reverse the direction of the flood tide on the surface to produce a southerly current, while flood currents below the surface have a strength of 0.5 knot toward the north. Current charts for the Narragansett Bay are published in Special Fublication No. 208 of the Coast and Geodetic Survey entitled, "Currents in Narragansett Bay, Buzzards Bay, and Nantucket and Vineyard Sounds." Current observations in Narragansett Bay are contained in a report of the Narragansett Marine Laboratory of the University of Rhode Island. 


\section{B-5. TEMPERATURE}

Nunerous observations were taken by the Narragansett Marine Laboratory of water temperatures in Narragansett Bay. Surface temperatures observed at the head and mouth of the bay in February 1956 showed no variation, being constant at 360F. Bottcm temperatures, however, were recorded at $360 \mathrm{~F}$ at the head of the bay and $340 \mathrm{~F}$ at the mouth. From these observations, it can be noted that the temperature at the surface was the same as at the bottom in shallow water, but varied about $20 \mathrm{~F}$ for deep water. Tests that were made in April and June 1956, however, showed much greater horizontal and vertical variations (see Table B-2).

Temperature observations were made in March 1956 near Hewport during a complete tidal cycle. Surface temperatures remained constant at about $360 \mathrm{~F}$. The average water temperature at the bottom was the same, with a maximun occurring about 1 hour after high tide (400F) and a minimum about 3 hours after low tide (330F). It is believed that these extremes are due to hot and cold eddy currents.

\section{B-6. SAIINITY}

The results of observations made by the Narragansett Marine Laboratory indicate that the salinity over much of Narragansett Bay is generally high. This is attributed to the relatively small quantity of fresh water entering the bay from the Providence and Taunton Rivers, and to the fact that this fresh water remains on the surface until it is gradually absorbed near the middle of the bay. In fact, the salinities in the region from the southern end of Prudence Island to the mouth of the bay are virtually constant with depth. An analysis of the observations made by the Narragansett Marine Laboratory shows that the salinity of the surface water at the head of the bay is less than at the mouth. This is particularly noticeable around April, and is undoubtedly due to the heavy spring runoff from the rivers. The bottom salinities for the entire bay, on the other hand, are relatively constant throughout the year (see Table B-2).

During tidal cycle observations in March 1956, salinity observations showed the effect of the tidal action and the presence of the less dense fresh water on the surface. The most pronounced differences between top and bottom salinities occurred shortly after slack water. After slack before ebb the surface selinities dropped more rapidly than the bottom salinities, whereas after slack before llood the bottom salinities increased more rapidly than the surface salinities. Table B-2 also contains the recorded data on salinity for the full tidal cycle on March 26, 1956 in the lower East Passage. 


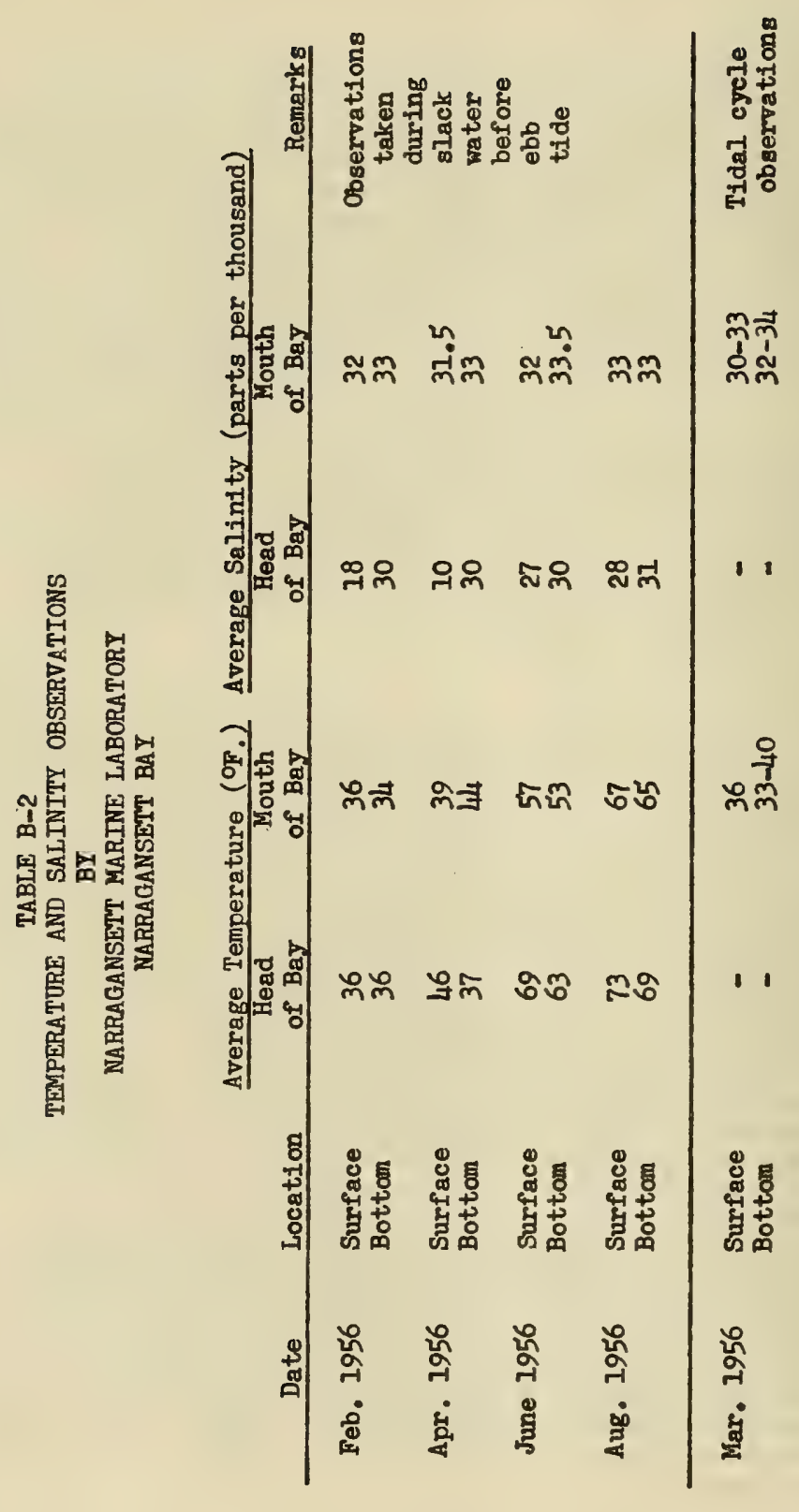




\section{B-7. FLUSHIVIG}

The flushing rate in Narragansett Bay, defined as the time required for a particle in the water to move from Providence to the mouth of the bay, varies during normal conditions from 42 to 59 days. It is described in detail in a report of the Narragansett Marine Laboratory. A tabulation showing a comparison of the flushing rates with and without the Lower Bay barriers is included in paragraph B-33.

\section{B-8. SIIPTHG}

Sedimentation studies were undertaken by the Harragansett Marine Laboratory in the spring and sumer of 1956 to determine the general nature of the present bottom surface sediments in Jpper and Lower Narragansett Bay and in Mount Hope Bay. Of samples of material taken in the Upper Bay and in Mount Hope Bay 80 to 95 percent was silt or clay. This is undoubtedly due to the deposition of large quantities of waste and sewage that are carried down by the Frovldence and Taunton Rivers. The results of the samples taken in the Lower Bay indicate, as may be expected, that the percentage of coarser materials is 3 to 4 times higher than the fine silt and clay. Haintenance of dredged navigation channels in the Providence River indicates about 0.1 foot per year of sedimentation.

\section{B-9. RECORDING TIDE GAGES IN NARRAGANSETT BAY}

of the 15 locations in this area for which the U.S. Coast and Geodetic Survey has published tidal data, two have perwanent recording gages. The information for the other localities was established by making observations with temporary installations. The principal recording tide gage, upon which the tidal data for the area are based, is the installation on Coasters Harbor Island, Newport. ThIs gage was established in September 1930, and has been in operation since with the exception of brief periods following the hurricanes of 1938 and 1954. The other recording gage is located at State Pler Ho, I in Provldence. This was installed in Jwe 1938, and was in operation until May 1947, except for sereral months after being danaged by the September 1938 hurricane. There has been no permanent gage at this point from May 1947 until August 1956, when the location was re-established.

\section{B-10. CORPS OF ENGINEERS' TIDE GAGE PROGRAH}

As part of its program of establishing recording and nonrecording tide gages al ong the Her Finglend coast, the Ner England Division, Corps of Engineers, has installed 16 recording gages, 
nine maximum level gages designed to indicate maximum high water levels, and 15 staff-type gages along the New England coast line. The program supplements tidal data at installations of the U.S. Coast and Geodetic Survey and others. Table B-3 is a summary of the existing and proposed tide gage installations of the New England Division along the New England coast including the Narragansett Bay area. 
TIDE GAGES - RECORDING AND NON-RECORDING, NEW ENGLAND DIVISION, CORPS OF ENGINEERS

\section{Type of Gage Maximum Location}

1. Fishers Island, N.Y. Coast Guard Station

2. Bridgeport, Conn. Installed Yellow Mill Bridge

3. Milford, Conn.

4. New Haven, Conn. City Point

5. New Haven, Conn. Tomlinson Bridge

6. Branford, Conn.

7. Duck Island, Conn.

8. Old Saybrook, Conn. Installed Saybrook Marine Service, Inc.

9. East Lyme, Conn. Niantic Piver Drawbridge

10. New London, Conn. State Pier

11. Stonington, Conn. Installed Thomas Boat Yard

12. Westerly (Watch Hill), R.I. Coast Guard Station

13. Block Island, R.I. Installed old Harbor

\section{Proposed}

Installed

Installed

Proposed

do

Installed

Installed

Proposed

do

Installed

Installed

Proposed

do

Installed

Installed

Proposed

Proposed

Installed 


\section{TABLE B-3 (continued)}

TIDE GAGES - RECORDING AND NON-RECORDING,

NEW ENGLAND DIVISION, CORPS OF ENGINEERS

\begin{tabular}{|c|c|c|c|c|}
\hline \multirow{2}{*}{\multicolumn{2}{|c|}{ Location }} & \multicolumn{3}{|c|}{ Type of Gage } \\
\hline & & Recorder (1) & $\begin{array}{l}\text { Maximum } \\
\text { Level(2) }\end{array}$ & Staff (3) \\
\hline 14. & $\begin{array}{l}\text { Narragansett } \\
\text { (Galilee), R.I. } \\
\text { Coast Guard Boathouse }\end{array}$ & Installed & Installed & Installed \\
\hline 15. & $\begin{array}{l}\text { Saunderstown, R.I. } \\
\text { Narragansett Marine } \\
\text { Laboratory }\end{array}$ & do & Proposed & do \\
\hline 16. & $\begin{array}{l}\text { North Kingstown, R.I. } \\
\text { Quonset Naval Air } \\
\text { Station }\end{array}$ & do & do & Proposed \\
\hline 17. & $\begin{array}{l}\text { Cranston, R.I. } \\
\text { Edgewood Yacht Club }\end{array}$ & do & do & Installed \\
\hline 18. & $\begin{array}{l}\text { Somerset, Mass, } \\
\text { Montaup Electric Co. }\end{array}$ & do & do & do \\
\hline 19. & $\begin{array}{l}\text { Portsmouth, R.I. } \\
\text { Weyerhaeuser Timber } \\
\text { Co. }\end{array}$ & do & do & do \\
\hline 20. & $\begin{array}{l}\text { Newport, R.I. } \\
\text { Castle Hill Coast } \\
\text { Guard Station }\end{array}$ & do & do & do \\
\hline 21. & $\begin{array}{l}\text { Little Compton } \\
\text { (Sakonnet), R.I. } \\
\text { Holder Wilcox Dock }\end{array}$ & do & Installed & do \\
\hline 22. & $\begin{array}{l}\text { South Dartmouth, Mass. } \\
\text { Davis \& Tripp, Inc. } \\
\text { Dock }\end{array}$ & - do & do & do \\
\hline 23. & $\begin{array}{l}\text { Yarmouth (Bass R.), } \\
\text { Mass. Ship Shops, Inc }\end{array}$ & do & do & do \\
\hline
\end{tabular}


TABLE B-3 (continued)

TIDE GAGES - RECORDING AND NON-RECORDING, NEW ENGLAND DIVISION, CORPS OF ENGINEERS

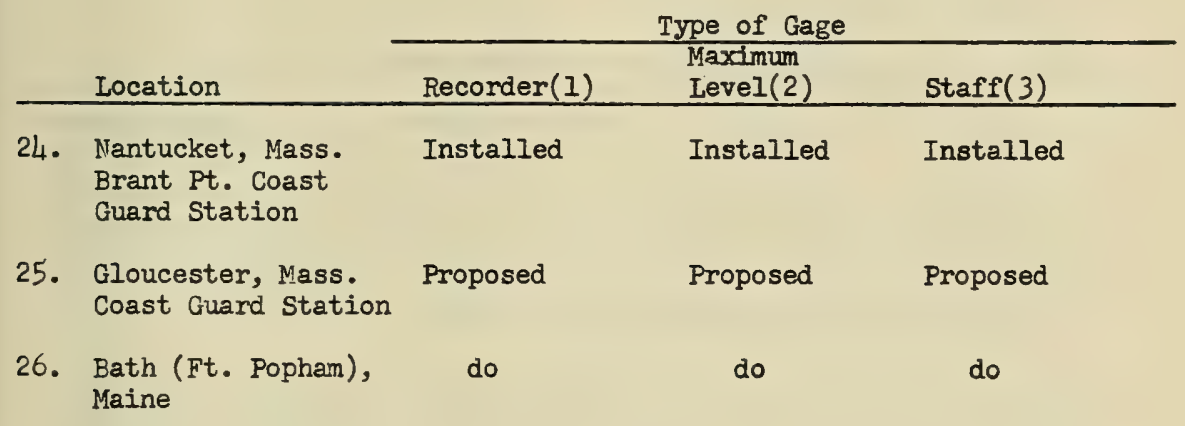

(1) Pressure diaphragm connected to mechanically operated recorder.

(2) Wood indicator rod inclosed in 2-inch pipe containing ground cork.

(3) Wood staff with markings in feet and tenths of a foot. 
HURRICANE TIDAL FIOODING

\section{B-11. GENERAL}

In the last 18 years the Narragansett Bay area has been subjected to severe tidal flooding from two major hurricanes those of September 1938 and August 1954 (Carol) - and moderate flooding from the hurricane of September 1944. Minor flocding has also occurred as the result of about 22 other hurricanes and severe storms in the past 50 years. Detailed descriptions of these three hurricanes are given in the following paragraphs.

\section{B-12. HURRICANE OF SEPTEMBER 21, 1938}

The damage caused by tidal flooding from this hurricane was the highest ever experienced in the Narragansett Bay area. Probably the most significant factor, which produced the record high water, was that the peak of the wind-induced tidal surge arrived at approximately the time of the predicted high tide. At Newport Harbor, where the water attained a height of 10.8 feet above mean sea level, the hurricane tide occurred approximately three-quarters of an hour before the normal high tide, but at Providence and Fall River-Somerset, Massachusetts, the two occurred at about the same time and reached elevations of 15.7 and 13.7 feet, m.s.1., respectively. Pertinent data concerming tidal heights, wind velocities and barometric pressures are included in Table $\mathrm{B}-4$.

The winds accompanying the hurricane of September 1938 were generally in excess of $75 \mathrm{~m} . \mathrm{p.h}$. in the Narragansett Bay area. At Block Island, the wind attained a maximum recorded 5-minute sustained velocity of $\delta 2 \mathrm{~m} . \mathrm{p} . \mathrm{h}$. from the southeast and maximum gusts of $91 \mathrm{~m} . \mathrm{p} . \mathrm{h}$. before the anemometer was blown down. A maximum 5-minute velocity of $87 \mathrm{~m} . \mathrm{p} . \mathrm{h}$. from the southwest and gusts of $125 \mathrm{~m} . \mathrm{p} . \mathrm{h}$. occurred at Providence. Minimum barometric pressures of 28.66 and 28.90 inches, respectively, were recorded at Block Island and Provicence. The forward speed of the hurricane near $\mathrm{N}_{2}$ rragansett Bay was about 55 knots $(63 \mathrm{~m} . \mathrm{p} . \mathrm{h}$.). Tide curves showing the predicted and estimated tidal elevations at Newport, Providence and Fall River - Somerset are included as Plate B-I. Hurricane flood levels based on observed high water marks, along the east shore of Narragansett Bay are shown on Plate B-6, and for the Sakonnet River (from Sakonnet Point), Mount Hope Bay and the Taunton River as far as Dighton, Massachusetts, on Plate B-7. The high water profile for the west shore of Narragansett Bay is similar to the east shore, as indicated by office records. 
The peak of the wind-induced tidal surge of this hurricane arrived shortly before the time of the predicted low tide and therefore caused only moderately high stages. The water reached an elevation of 3.6 feet above m.s.1. at Block Island, 6.6 feet above m.s.1. at Newport, and 9.9 feet above m.s.1. at Providence. These elevations were 4.0 feet, 7.7 feet, and 11.6 feet, respectively, above the predicted tidal heights (see Table B- 4 for further data).

Wind velocities during this hurricane were somewhat less than in the September 1938 storm. A one-minute sustained velocity of $88 \mathrm{~m} . \mathrm{p} . \mathrm{h}$. from the southeast was recorded at Block Island and of $49 \mathrm{~m} . \mathrm{p} . \mathrm{h}$. from the southeast at Hillsgrove, Rhode Island. Maximum gusts in excess of 100 m.p.h. were experienced at Block Island and in excess of $90 \mathrm{~m} . \mathrm{p} . \mathrm{h}$. at Hillsgrove. The forward speed of the hurricane near Narragansett Bay was about 30 knots ( 35 m.p.h.). Additional pertinent data regarding this hurricane are contained in Table $\mathrm{B}-4$; the predicted and experienced tide curves at Newport and Providence are shown in Plate B-2.

\section{B-14. HURRICANE OF AUGUST 31, 1954 (CAROL)}

This hurricane caused tidal flooding in the Narragansett Bay area about one foot below the September 1938 flood levels. However, if the tidal surge had arrived at the same time as the predicted high tide, instead of between $I$ and 2 hours later, the maximum high water would have been about 0.7 foot higher than in 1938. The hurricane tide at Block Island reached a height of 8.2 feet above m.s.1.; at Newport Harbor it attained an elevation of 9.8 feet above m.s.1.; and at Providence, 14.7 feet above m.s.l. Relative to the heights of the predicted tide at Block Island, Newport, and Providence, these elevations were, respectively, 6.3 feet, 8.1 feet, and 13.3 feet. Table B- 4 contains pertinent data on this storm.

The wind attained a maximum one-minute sustained velocity of 98 miles per hour from the southeast, with maximum gusts of 135 miles per hour at Block Island. A maximum one-minute sustained wind velocity of 90 miles per hour from the eastsoutheast, with maximum gusts of 105 miles per hour, occurred at Hillsgrove, Rhode Island. Minimum barometric pressures of 28.50 inches were recorded at Block Island and 28.79 inches 


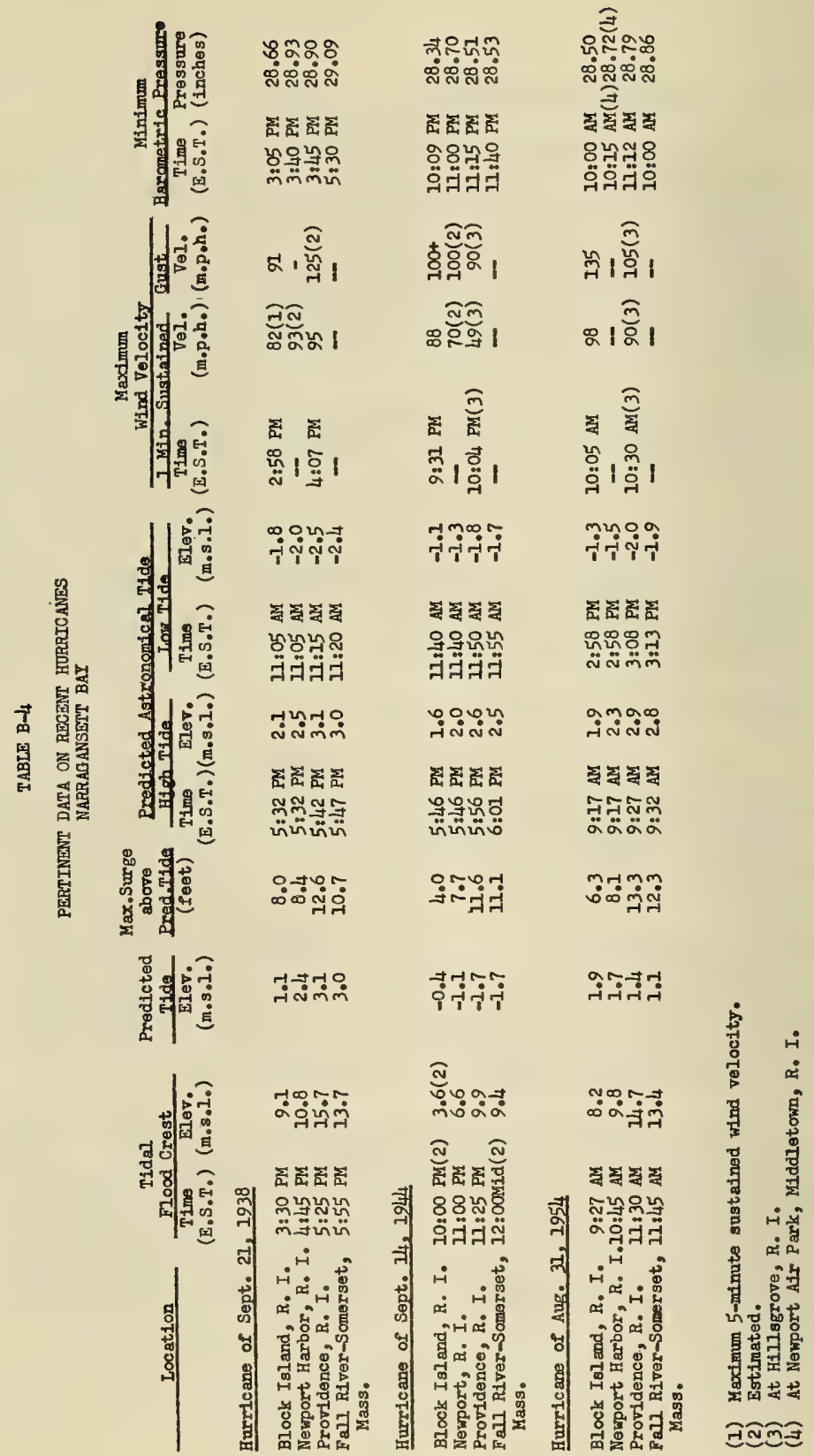


at Providence. The forward speed of the hurricane close to Narragansett Bay was about 40 knots. Tide curves at Newport, Providence, and at Fall River-Somerset are shown on Plate B-3. Hurricane flood levels are shown on Plates B-6 and B-7 for the same areas as for the September 1938 hurricane (see paragraph $\mathrm{B}-12)$.

\section{B-I5. FREQUENCY OF TIDAL FLOODING}

Although hurricane tidal flooding has been recorded since $1635^{\circ}$ in the Narragansett Bay area, records are meager as to elevations and number of occurrences until recent years. A flood frequency relationship has been approximated using the records of the U. S. Coast and Geodetic Survey gages of the last 25 years and adjusting the records of the great floods of 1938 and 1954, which occurred in this period, to a 1lil-year period for which newspaper accounts are available on disastrous tidal floods.

Table B-5 gives a chronological list of hurricanes or severe storms causing tidal flooding or high tides in the Narragansett Bay area, with available data regarding the maximum tidal elevation at Providence. Plate B- 4 is a graphical presentation of the same data. Information regarding these hurricanes and severe storns was obtained by a historical search of the original sources of iniormation, as described in Appendix A.

\section{TABIE B-5}

HURRICANES OR SEVERE STORNS

NARRAGAiNSETT BAY AREA

(1635 to 1955)

Maximum Tidal Elevation at Provilence, R.I.

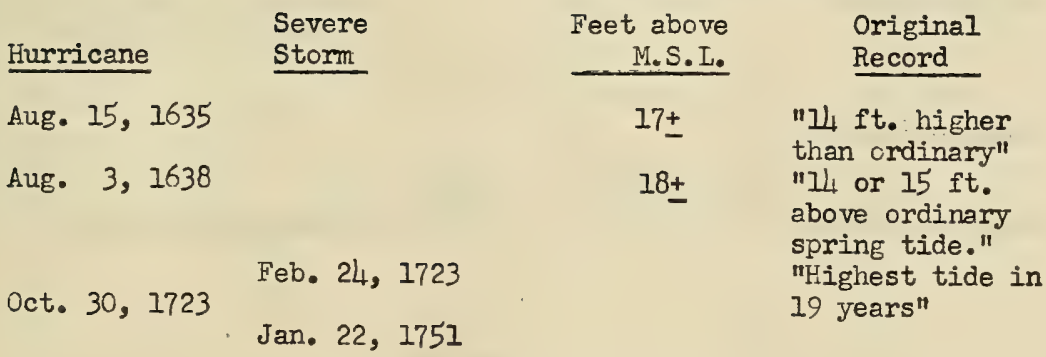


TABLE B-5 (cont'd)

HURRICANES OR SEVERE STORMS

NARRAGANSETT BAY AREA

(1635 to 1955)

Maxdmum Tidal Flevation at Providence, R.I.

Hurricane
1757
Oct. 24,1761
Oct. $19-20,1770$

Severe Feet Above Original

Storm M.S.L. Record

Aug. 1773

$$
\text { Aug. } 12,1778
$$

Aug. 19, 1788

Sept. 9, 1804

Oct. $9-10,1804$

Sept. 23, 1815

Sept. 3, 1821

Sept. 25, 1821

July 24, 1829

Oct. 3,1841

Sept. 10-11, 1854

oct. 30,1866

Feb. 8, 1869

Sept. 8, 1869

8.6 "6.2 ft. above mean high

Oct. 4-5, 1877

Oct. 23,1878

Dec. 10,1878

$8+$ Water flowed into West Water and Dyer Streets"

I4.2 "II.8 ft. above mean high
tide" water"

$7+\frac{7+}{7+}$ Water washed over the Dorrance Street Wharf"

Aug. 16-20, $1879 \begin{array}{r}\text { July 16, } 1879 \\ \text { Feb. 11, } 1886 \\ \text { July 12, } 1888\end{array}$

Sept. 10, 1889

$7 \pm \quad$ "Unusually high tide" 


\section{TABLE B-5 (cont'd)}

HURRICANES OR SEVERE STORMS

NARRAGANSETT BAY AREA

$$
\text { (1635 to 1955) }
$$

Maximum Tidal Elevation at Providence, R.I.

Hurricane

Aug. 24, 1893

Aug. 29, 1893

Sept. 9-10, 1896

June 17, 1902

June 29, 1902

Sept. 16, 1902

Sept. 16, 1903

Sept. 15,1904

Nov. 9-14, 1904

Aug. 30, 1911

Sept. 16, 1912

July 21, 1916

oct. 1,1920

Aug. 26, 1924

Oct. 3, 1929

Sept. 14, 1933

Sept. 17, 1933

June 19, 1934

Sept. 9, 1934

Sept. 19, 1936

Sept. 21, 1938

Sept. 3, 1940

\section{Sept. 21, 1938}

Jan. 27, 1933 Est. 7.1

Est. 5.2

Est. 4.9

Est. 5.2

Oct. 1, 1936 Est. 6.6

15.7

Apr., 1939

5.2
4.7

Apr., 1940
Original

Record

\section{Aug. 20, 1893}

Feb. 7-8, 1895

"Tide $3 \mathrm{ft}$. above mean high water" 


\section{TABTE B-5 (cont'd) \\ HURRICANES OR SEVERE STORMS \\ NARRAGANSETT BAY AREA}

(1635 to 1955)

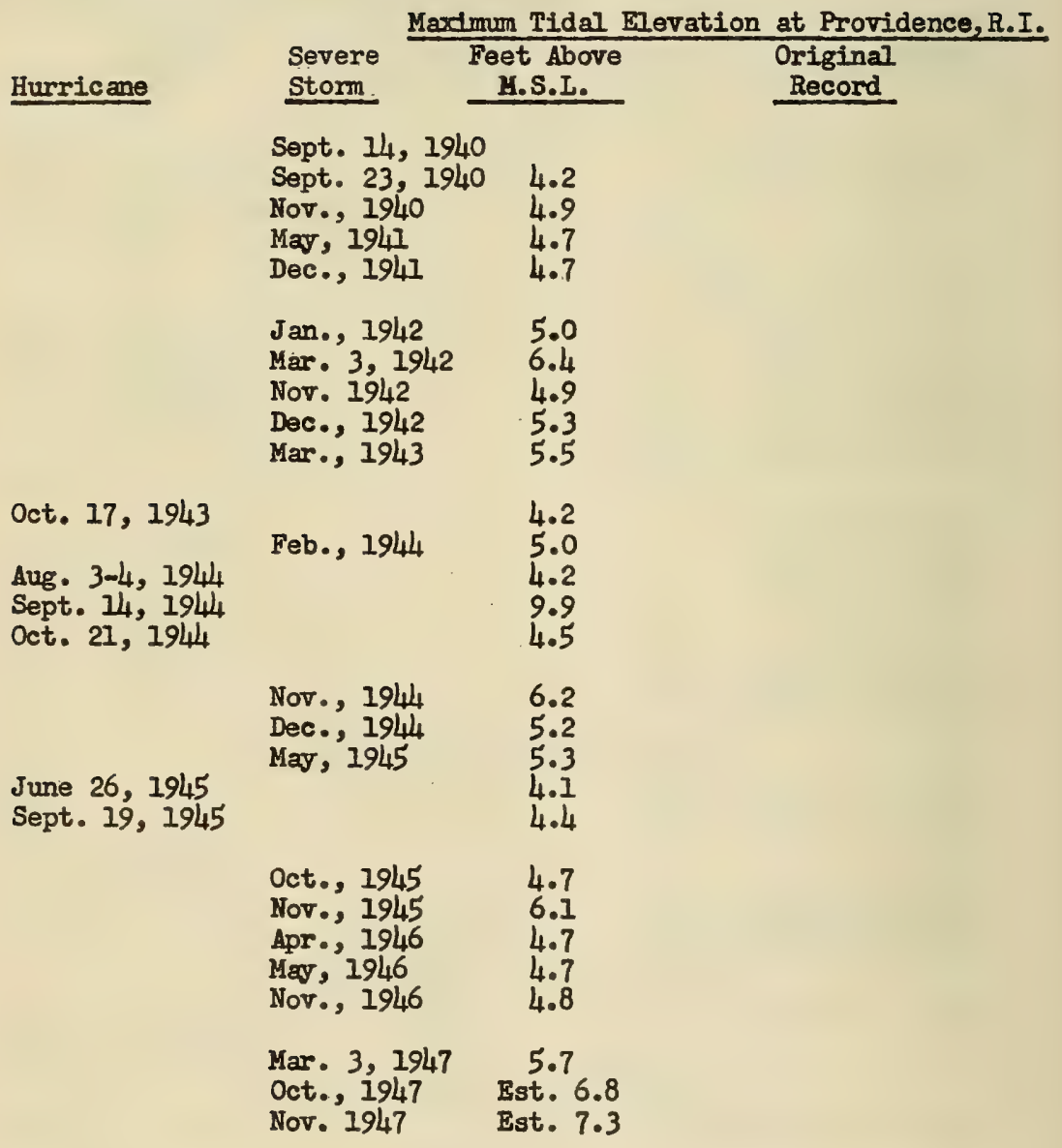




\author{
TABLE B-5 (cont'd) \\ HURRICANES OR SEVERE STORMS
}

NARRAGANSETT BAY AREA

(1635 to 1955)

Maximum Tidal Elevation at Providence, R.I.

Hurricane

Severe

Storm Feet Above

M.S.I.

Original

Est. 6.2

Aug. 29, 1949

Aug. 1, 1950

Aug. 20,1950

Sept. 11, 1950

"Able"

Sept. I, 1952

"Barbara"

Aug. 15, 1953

Feb., 1953 Est. 6.9

Apr., 1953 Est. 6.6

Nov. 25, $1950 \quad 6.8$

Dec. 4, 1950

Dec. 8, 1950

Feb. 7, 1951 Est. 7.2

Nov. 7, $1951 \quad 5.1$

Mar. 11, 1952

"Carol"

Sept. 7, 1953

"Carol"

Aug. 31, 1954

Oct. 1953

Nov. 7, 1953

Est. 5.5

Est. 5.2

Est. 6.8

Est. 7.9

I4. 7

"Dolly"

Sept. 3, 1954

"Edna"

Sept. 11, 1954
Record 


\section{TABLE B-5 (cont'd)}

HURRICANES OR SEVERE STORMS

NARRAGANSETT BAY AREA

(1635 to 1955)

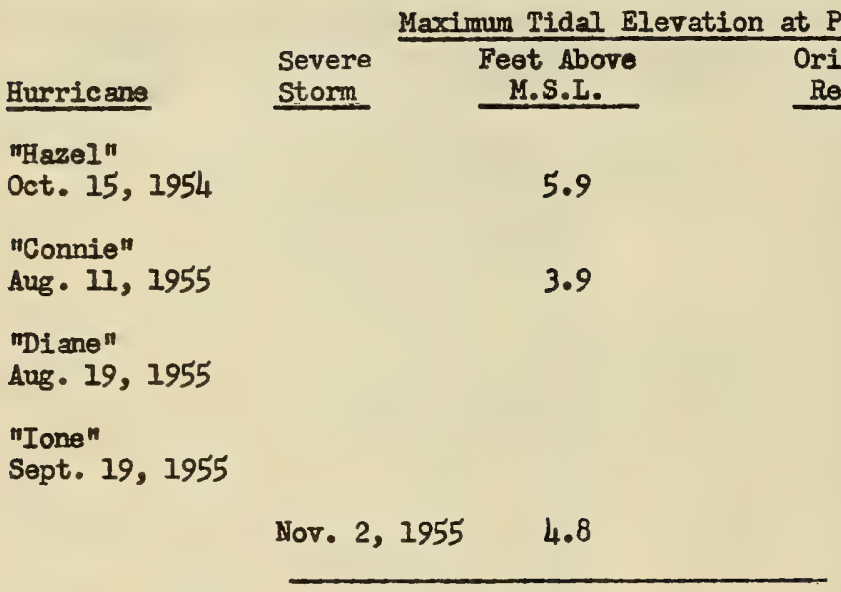

Table B -6 shows the tidal flood elevations rearranged in order of magnitude with calculated plotting positions in percent chance of occurrence in any one year based on three periods; (1) the period from 1931 to 1955 ( 25 years) for which records are available at Newport or Providence; (2) the period from 1815 to 1955 (14l years) to include newspaper accounts of great floods; and (3) the 321-year period between 1635 and 1955 for the purpose of plotting the approximate elevations of the 1635 and 1638 floods. A tidal flood elevation-frequency curve for Providence is given in Plate B-5. The estimated frequency of recent hurricanes and the design tidal flood is indicated in the following tabulation:

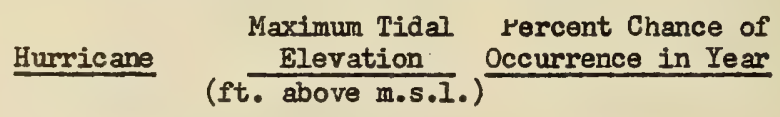

$\begin{array}{lll}\text { September } 21,1938 & 15.7 & 1.10 \\ \text { August 31, 1954 (Carol) } 14.7 & 1.70 \\ \text { Design tidal flood } & 18.7 & 0.28\end{array}$




\section{TABLE B-6}

\section{ELEVATION - FREQUENCY DATA HURRICANES OR SEVERE STORMS PROVIDENCE, RHODE ISLAND}

Percent Chence of Occurrence

Hurricane Estimated Max. In Any One Year (1) or Storm Tidal Elevation

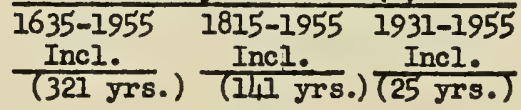

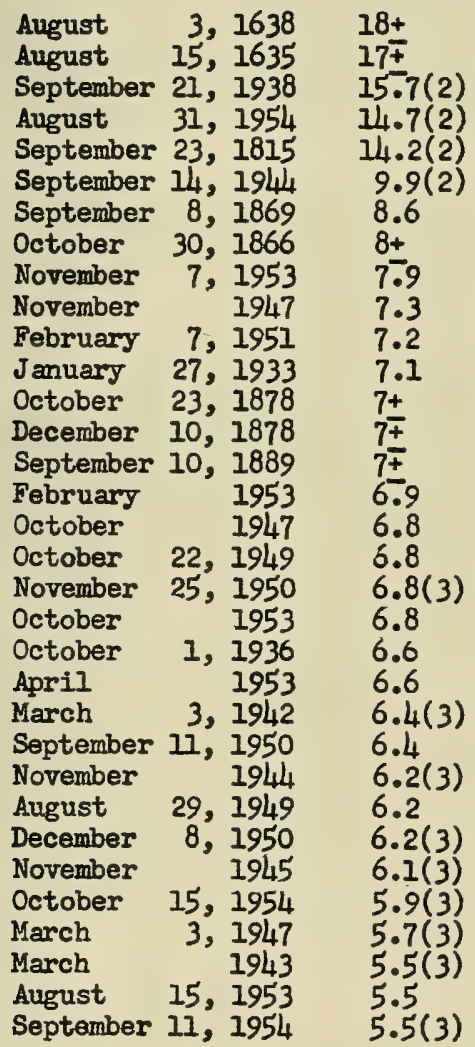

0.31

0.62

$0.71 \quad 4.00$

$1.42 \quad 8.00$

2.13

12.00

16.00

20.00

24.00

28.00

32.00

36.00

40.00

44.00

48.00

52.00

56.00

60.00

64.00

68.00

72.00

76.00

80.00

84.00

88.00

92.00

96.00

100.00

(1) Calculated plotting positions

(2) Based on high water mark

(3) Based on tide gage reading 


\section{B-16. WIND FIELD}

Charts prepared by the Hydrometeorological Section of the J.S. Weather Bureau have provided basic data for use of the Beach Erosion Board, the Texas A \& M Research Foundation, the Waterways Experiment Station, and the New England Division, Corps of Engineers, for determination of the design hurricane tide elevations in Narragansett Bay. The charts depict the wind flow over Narragansett Bay for the September 19/4 hurricane, transposed to a track over water from Cape Henry, Virginia. The hurricane is assumed to be moving on a hypothetical path due north with a speed of 40 knots, so as to pass 49 nautical miles due west of a point at the mouth of Narragansett Bay which produces a wind field most critical to the area. Maximum winds over a major portion of the bay average 76 miles per hour at the height of the storm.

The transposed September 1944 hurricane, described above, was used for the design hurricane tidal flood. Determination of the maximum probable hurricane has not been completed.

\section{B-17. STORM SURGE AT MOUTE OF BAY}

Preliminary computations of the water level variations at the mouth of Narragansett Bay for the design hurricane have been carried out for five selected storm speeds. More detailed calculations were made for 20 and 40 knot storm speeds. These have been made by the Texas A \& M Research Foundation under contract to the Beach Erosion Board. The procedure is similar to that discussed in Report 127-1 of the Texas A \& M Research Foundation. A summary of preliminary results for the design hurricane follows:

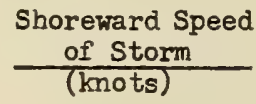

20

40

$$
\begin{aligned}
& \text { Storm Tide } \\
& \text { Potential } \\
& \text { (feet) }
\end{aligned}
$$

$$
10.3
$$$$
9.5
$$

The storm tide noted is the maximum water level rise at the mouth of the bay due to winds and inertial effects alone. 


\section{B-18. STORM SURGE IN NARRAGANSETT BAY}

The storm surge analyses provided by Texas A \& M Research Foundation were the basis for surge determination in the bay using the hydraulic model. The results of the model tests, without wind effects, conducted by the Waterways Experiment Station, are tabulated below:

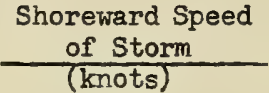

20

40

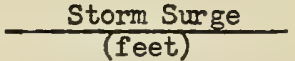

Newport, R.I. Providence, R.I.

$$
\begin{array}{rr}
10.3 & 12.4 \\
9.5 & 12.2
\end{array}
$$

The determination of wind effect to be added to the model results is complicated by the irregularities of configuration and hydrography in the 25.5-mile fetch of the bay and the wind pattern that might apply between the mouth and head. Calculations using a steady wind of 76 miles per hour gave a wind set-up of approximately 3.0 feet. More detailed analytical studies by Texas $A$ \& $M$ Research Foundation are in progress. These indicate that the transient winds of a hurricane might possibly increase the wind effect to 5 feet.

\section{B-19. SELECTION OF DESIGN STORM SURGE}

The 20-knot storm speed was adopted for the tidal design flood because of its higher elevation and greater volume at the mouth of the bay, making it a more severe test of barrier structures. Recognizing the desirability of continuing research, storm surges of 10.4 feet and 15.6 feet, respectively, were selected for Newport and Providence. These adopted surges, when applied upon spring tide elevations of 2.6 feet above m.s.I.

\begin{tabular}{|c|c|c|}
\hline $\begin{array}{l}\text { Adopted Storm Surge (feet) } \\
\text { Spring Tide Elevation }\left(m_{\bullet} \text { s.l. }_{*}\right)\end{array}$ & $\begin{array}{r}10.4 \\
2.6 \\
\end{array}$ & $\begin{array}{r}15.6 \\
3.1 \\
\end{array}$ \\
\hline $\begin{array}{c}\text { Design Hurricane Elevation } \\
\left(m_{. s .1 .}\right)\end{array}$ & 13.0 & 18.7 \\
\hline
\end{tabular}
at Newport, and 3.1 feet above m.s.l. at Providence, are as follows:

Design Hurricane Elevations Newport, R.I. Providence, R.I. 
For comparison, the September 1938 storm surge, which was used as a basis for storm surge studies by Texas A \& M Research Foundation and Waterways Experiment Station model studies, follows:

1938 Hurricane Tide Peak, m.s.l.

Coincident Predicted Astronomical

$$
\text { Tide, m.s.l. }
$$

Difference, or Storm Surge, feet

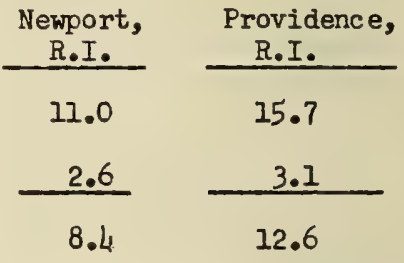

The experienced storm surges in Hurricane Carol in 1954 were 8.3 feet at Newcort and 13.3 feet at Providence.

B-20. WAVES

Significant wave heights in the design hurricane have been furnished by the Beach Frosion Board at proposed barrier locations in Narragansett Bay. In general, they are greatest in the Lower Bay and diminish in size up the bay to a minimum at Providence. The following tabulation summarizes significant wave heights and periods with wind from the south.

\section{Location}

Lower Bay, East Passage

Lower Bay, West Passage

Middle Bay, East Passage

Middle Bay, West Passage

Tiverton - Island Park

Fields Point

Fox Point

$\frac{\text { Wave Height }}{\text { (feet) }} \frac{\text { Wave Period }}{\text { (seconds) }}$

$\begin{array}{ll}25 & 11 \\ 20 & 11 \\ 6 & 5 \\ 7.5 & 5.5 \\ 9 & 7 \\ 8 & 6 \\ 6 & 5\end{array}$

EFFECT OF BARRIERS ONT TIDAL FLOODING

B-21. GENERAL

Investigations to determine the effects of proposed barrier plans on hurricane-tide elevations throughout Narragansett Bay are based mainly on hydraulic model tests. 
The model at the Waterways Experiment Station reproduces all of Narragansett Bay and a portion of the Atlantic Ocean adjacent to the bay entrance and consists of fixed-bed construction with scale ratios, model to prototype, of $1: 1000$ horizontally and $1: 100$ vertically. Dimensions of the model are approximately 100 feet wide and 250 feet long, and cover about 15,000 square feet. An automatic tidegenerator is used to reproduce normal tides throughout the model, and a separate automatic tide generator is used to reproduce hurricane tides of the desired characteristics at the bay entrance. Fresh water only was used in the model during tests to determine the effectiveness of the proposed barriers in reducing hurricane-tide damage. Appurtenances that are used in the model consist of automatic and manually operated tide gages to record hurricane-tide elevations at critical points throughout the bay system.

\section{B-23. MODEL TESTING PROGRAM}

Following the construction of the model and tidal generators, adjustments were made to reproduce normal tide conditions in Narragansett Bay as well as the hurricane tides of September 21, 1938, September 14, 1944, and August 31, 1954. The effect of the various barrier plans on hurricane tide conditions in the bay was then determined, using the September 1938 and the design hurricane tidal floods.

a. Middle Bay barriers. Barriers were tested with openings ranging from 720 feet $x 40$ feet in the East Passage, 400 feet x 20 feet in the West Passage, and 400 feet $\times 40$ feet in the East Passage with gated openings in the West and Tiverton barriers. The latter test, for the 1938 hurricane conditions, gave very effective protection with a rise of only one foot above predicted high tide at Providence. Allowing 2 feet of wind effect would result in a rise in elevation of about 6 feet at Providence, which is below zero damage stage. At the same time, however, the build-up south of the Middle Bay barriers was about 1.5 to 2.0 feet, diminishing to approximately 0.5 feet near Newport. Thus tidal flooding would be increased in the area below the barriers and the Middle Bay barriers were dropped from further consideration. 
b. Lower Bay barriers. Barriers were tested for openings ranging from 1,550 feet $\times 50$ feet in the East Passage, 720 feet $x$ 40 feet in the West Passage, and 1,000 feet $\times 50$ feet in the East Passage with gated openings in the West and Tiverton barriers. All dimensions are referred to mean low water datum, with ungated openings having $I$ on $I \frac{1}{2}$ side slopes and gated openings having vertical sides. With minimum openings, the September 1938 flood indicated a rise of about one foot above predicted high tide at Providence.

Allowing for wind effect, water levels at Providence would be about 6.5 feet above mean sea level.

c. Fields Point barrier. Barriers with a gated navigation opening were tested. A build-up of 0.5 foot (including 0.2 foot from wind effect) is indicated south of the barrier for the design tidal flood. Levels above the barrier would depend on pumping of river flow from a 620-square-mile drainage area.

d. Fox Point barrier. The model studies indicated a relatively small build-up in flood levels south of the barrier.

\section{B-24. ANALYTICAL ROUTINGS}

In advance of hydraulic model studies analytical routing calculations were made for numerous barriers in the bay with variations in dimensions of navigation openings. These data supplemented studies at the Waterways Experiment Station. Calculations of velocities and water surface elevations were based on the routings predicated on storage in the 120-square-mile water area above the barriers and the formula:

$$
Q=C A \sqrt{2 g h}
$$

C = coefficient of discharge, varying between 0.64 and 0.80

$A=$ average cross-sectional area of opening

$g=$ acceleration of gravity, 32.2 feet per serma per second

$h=$ difference in water surface elevation between ocean and bay

A coefficient of 0.64 was generally used for $C$ and checked quite closely with the model results for current velocities through openings and effect on tidal fluctuations as to elevations and timing. 
Calculations made by the New England Division were based on a step method formula derived by the Beach Erosion Board:

$$
\begin{aligned}
\Delta S & =d_{T}\left[\sqrt{1+\frac{2 K U^{2} \Delta F}{d_{T}^{2}}}-1\right] \\
\Delta S & =\text { incremental wind set-up in feet } \\
d_{T} & =\text { average depth of water in feet } \\
U & =\text { velocity of wind in miles per hour } \\
\Delta \mathrm{F} & =\text { incremental fetch length in statute miles } \\
K & =\text { coefficient }\left(1.165 \times 10^{-3}\right)
\end{aligned}
$$

The above formula was used in deriving the wind set-up above the proposed site of the East barrier for a design hurricane with and without the barrier with $U=76 \mathrm{mph}$. A step method was used progressing up the 25.5 miles of bay with the depth of water varying according to the fetch length assumed. The depth ranged between 20 feet and 130 feet. Without the barrier in place, the initial elevation was the design hurricane elevation, 13 feet above $\mathrm{msl}$, in which the set-up was computed to be 3.0 feet. With the barrier in place, the initial elevation north of the barrier was elevation 4.5 feet above $\mathrm{msl}$, in which the total set-up computed was 3.5 feet. In the latter case, allowance was made for the tilting effect the wind creates on the water surface, depressing the lower end of the pool and raising the upper end. Furthermore, at Newport, due to the narrow opening which limits the flow of water through the proposed opening, the effect of a hurricane wind of $76 \mathrm{mph}$ is also to depress the water surface. It was assumed, therefore, that the Newport end of the pool would be 0.9 foot lower than the starting elevation and the upper end would be 2.6 feet higher than an elevation without wind at Providence. The latter modification was applied to model tests without wind effect.

The resulting high-water profile from model tests, reproducing the 1938 hurricane has a flat slope. At Newport, the model shows that stillwater levels (without wind set-up) are about 4.5 feet and at Providence about 5.1 feet above mean sea level. Wind set-up, calculated from the above formula and modified as described, was superimposed upon the model test profile for the 1938 hurricane tide resulting in an additional rise of about 2.6 feet at Providence, or a total rise of 7.7 feet above mean sea level as shown on Plate 8 of the main report. 
Studies of the estimated volume of water that would overtop the barriers were estimated using data obtained from a report entitled "Summary Report (Project CW-167), Waves and Wind Tides in Shallow Lakes and Reservoirs," published by the U.S. Army Engineer District, Jacksonville.

The amount of overtopping at the Fox Point barrier (without Lower Bay barriers) for the design tidal flood condition is estimated to be at an average rate of 1 cubic foot per second per foot, or, for the 800-foot effective length, 800 cubic feet per second. This is equivalent to 65 acre-feet or a 1.5 foot rise per hour over the 40 acres of water area; however, the purmps would be designed to keep the rise negligible. Overtopping would be eliminated with the Lower Bay barriers.

The amount of overtopping at the Lower Bay barriers for the design condition is tabulated below:

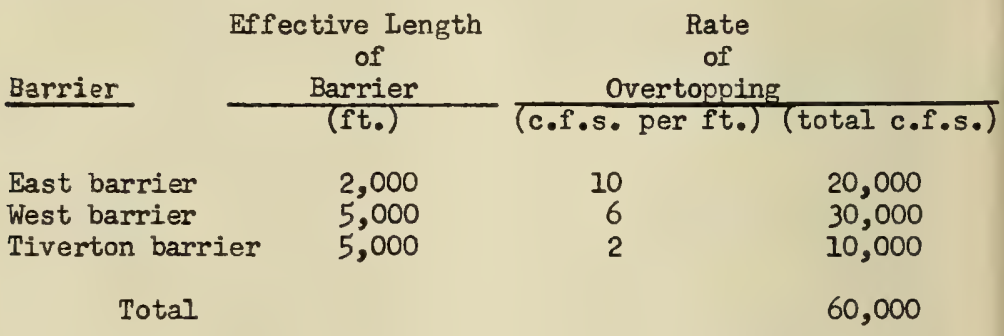

The approximate overtopping of 60,000 c.f.s. is equivalent to 5,000 acre-feet per hour, or a rise of about 0.1 foot per hour in the 120-square-mile water area above the Lo'ver Bay barriers. Therefore, the rise in level would be about 0.1 foot in a 4 -hour period of overtopping. Further studies are required on overtopping for riprap slopes and vertical walls.

\section{B-27. SUMRARY}

Based on the foregoing model tests and analytical calculations, the reductions in tidal flooding with the Lower Bay barriers are shown in Table B-7. 


\section{TABLE B-?}

EFFECT OF BARRIERS

ON

SEFTEMIER 1938 HURRICANE AND DFSIGN TIDAI, FLOODS

NARPAGANSETT BAY

\begin{tabular}{|c|c|c|c|c|}
\hline Location & $\begin{array}{l}\text { Septe } \\
\text { Without } \\
\text { Barriers } \\
\end{array}$ & $\begin{array}{l}\frac{\text { ximum Tidal }}{\text { ber 1938 }} \\
\text { Reduced by } \\
\text { Barriers }\end{array}$ & $\frac{\text { evation }}{\text { Design }}$ & $\begin{array}{l}\text {.1.) } \\
\text { al Flood } \\
\text { Reduced by } \\
\text { Barriers } \\
\end{array}$ \\
\hline $\begin{array}{l}\text { Newport, R.I. } \\
\text { Fall River and }\end{array}$ & 11.0 & 3.5 & 13.0 & 4.8 \\
\hline $\begin{array}{l}\text { Somerset, ilass. } \\
\text { Bristol, R.I. } \\
\text { Providence, R.I. }\end{array}$ & $\begin{array}{l}13.8 \\
13.6 \\
15.7\end{array}$ & $\begin{array}{l}5.1 \\
4.7 \\
7.7 \text { (1) } \\
0.0 \text { (2) }\end{array}$ & $\begin{array}{l}16.3 \\
16.1 \\
18.7\end{array}$ & $\begin{array}{l}6.3 \\
5.9 \\
8.9 \text { (1) } \\
3.0 \text { (2) }\end{array}$ \\
\hline
\end{tabular}

(1) Below Fox Point Barrier

(2) Above Fox Foint Barrier at Foint Street. Fresh water inflow would increase water levels in other parts of the protected area.

The openings through the barriers were selected as follows:

a. Fox Point Barrier. Four sluice gates, each 20 feet, wide and 24 feet high, which would be closed when the pumps were operating.

b. Lower Bay barriers.

(1) East Barrier. An ungated navigational opening 1,000 feet wide and 50 feet deep, referred to mean low water.

(2) West barrier. An ungated navigational opening 400 feet wide and 40 feet deep, referred to mean low water.

(3) Tiverton barrier. A closed ravigational opening 100 feet wide and 30 feet below mean low water. 


\section{EFF'EC'T OF BARRIERS ON NORMAL CONDITIONS}

\section{B-28. GENERAL}

Preliminary tests of the effects of the tidal barriers on present oceanographic conditions were made in the hydraulic model of Narragansett Bay after the model was adjusted to reproduce existing tides and currents. Basic information on present conditions in the bay was derived from the considerable data on temperatures, salinities, flushing rates and silting in the bay collected during 1956 by the Narragansett Marine Laboratory and from observations of the U.S. Coast and Geodetic Survey.

The effects of the Lower Bay barriers on present oceanographic conditions, such as tides, currents, temperature, salinity, flushing, sedimentation, fisheries, pollution and navigation, are exceedingly complex and will require extensive investigation over a period of years. As a result of these studies, the navigation openings in the barriers may be enlarged and sluice gates provided which would greatly diminish the effect of the barriers in restricting tidal circulation. The results of the preliminary studies are indicated below under appropriate headings.

\section{B-29, TIDES}

The model indicated that the Lover Bay barriers would reduce thi normal tide range at Providence by about 35 percent. This reduction occurs as a lowering of the high tide level by about 0.8 foot and the raising of the low tide level by a similar amount. No appreciable effect on the normal tide range would be caused by the Fox Point barrier.

\section{B-30. CURRENTS}

The Lower Bay barriers, with the exception of the Tiverton barrier, were tested in a flume using an undistorted scale model to determine the effects of normal tidal currents through the navigation openings. The tests indicated that currents through the navigation openings would increase in velocity from slack water for a period of about 3 hours until the maximum velocity of 4 to 5 knots is reached (as compared with a maximum velocity of 1.5 knots under normal conditions). The velocity would then decrease for another period of about 3 hours when slack water is again reached and the current begins a similar cycle in the opposite direction. 
The velocities through the openings would rapidly decrease to the existing currents in the bay above the barriers. Accurate measurements of velocity through the Tiverton barrier opening were not possible because of the small size of the model opening, but it is believed that the maximum velocity would be in the order of 5.5 knots. No appreciable change in the currents would be experienced through the Fox Foint sluice gates. A complete discussion of the current velocity tests conducted by the Waterways Experiment Station is included in the report of the Waterways Experiment Station.

\section{B-31. TEMPERATTRE}

Based on the temperature observations conducteu by the Narragansett varine Laboratory and on the conclusions derived from their salinitr studies, it is doubtful that the Lorer Bay barriers will cause any important change in the normal distribution of water temperatures as compared with the wide range of temperatures that occurs between flood and ebb, surface and bottom, and mouth to the head of the bay. Furtiner studies are being conducted by the Waterways Experiment Station to ascertain what effect, if any, the barriers will have on the water temperatures in the bay.

\section{3-32. SALINITY}

It is estimated that there will be some reduction in the salinity of the waters in Narragansett Bay due to the Lower Bay barriers. The exact amount of this reduction is the subject of further studies by the Waterways Experiment Station. The effects on salinity of the Lower Bay barriers are currently being tested in the model at Vicksburg.

\section{B-33. FLUSHING}

Preliminary studies by the Narragansett Marine Laboratory indicate that the flushing time for a particle to traverse the bay from Providence to Newport would be increased 3 to 23 days with Lower Bay barriers (see Table B-B). 
TABLE B-8

FLUSHING RATES

NARRAGANSETT BAY

Month

February

April

June

August
Without Barriers

45 days

42 days

45 days

59 days
With Barriers

54 days

45 days

65 days

82 days 


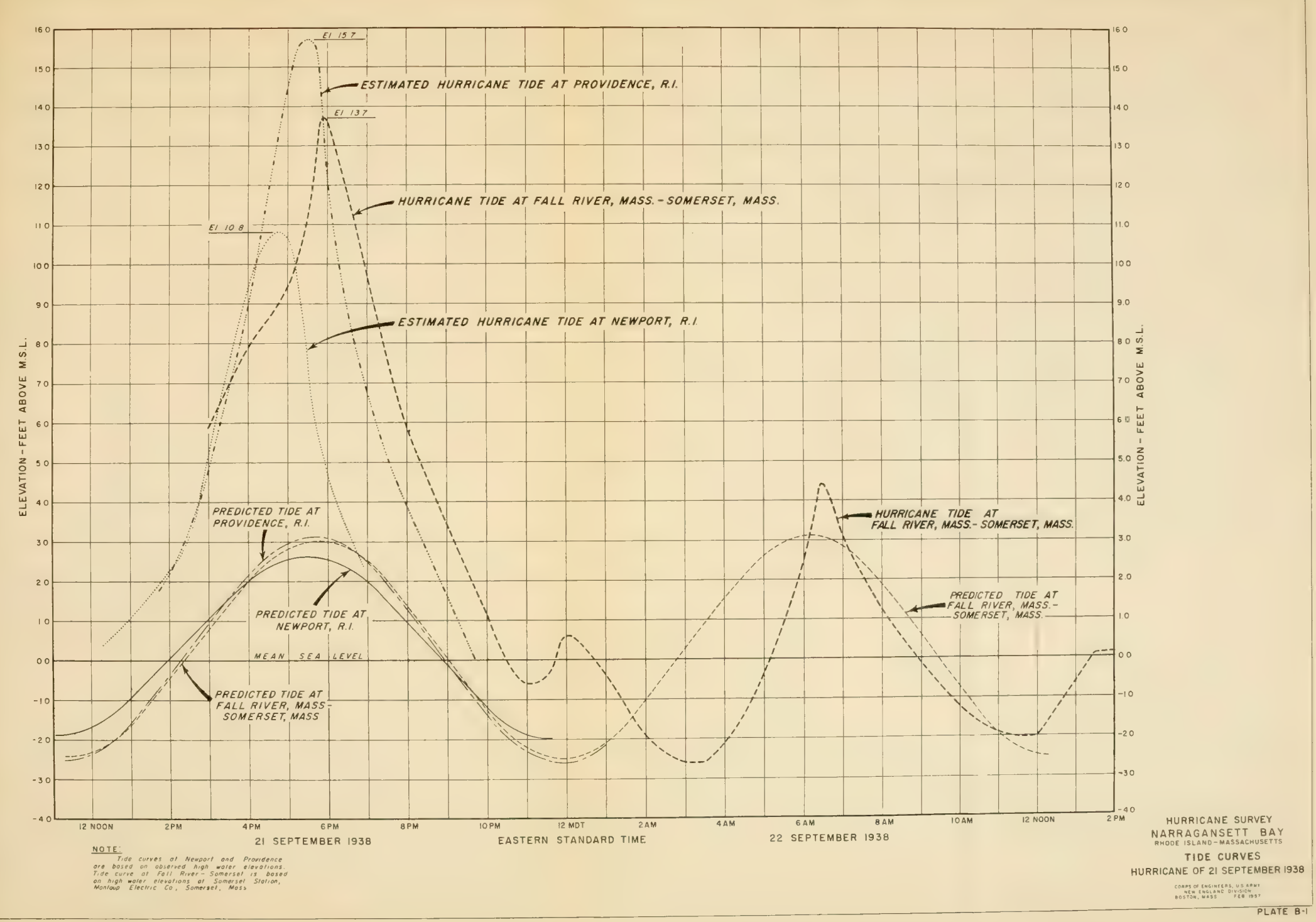





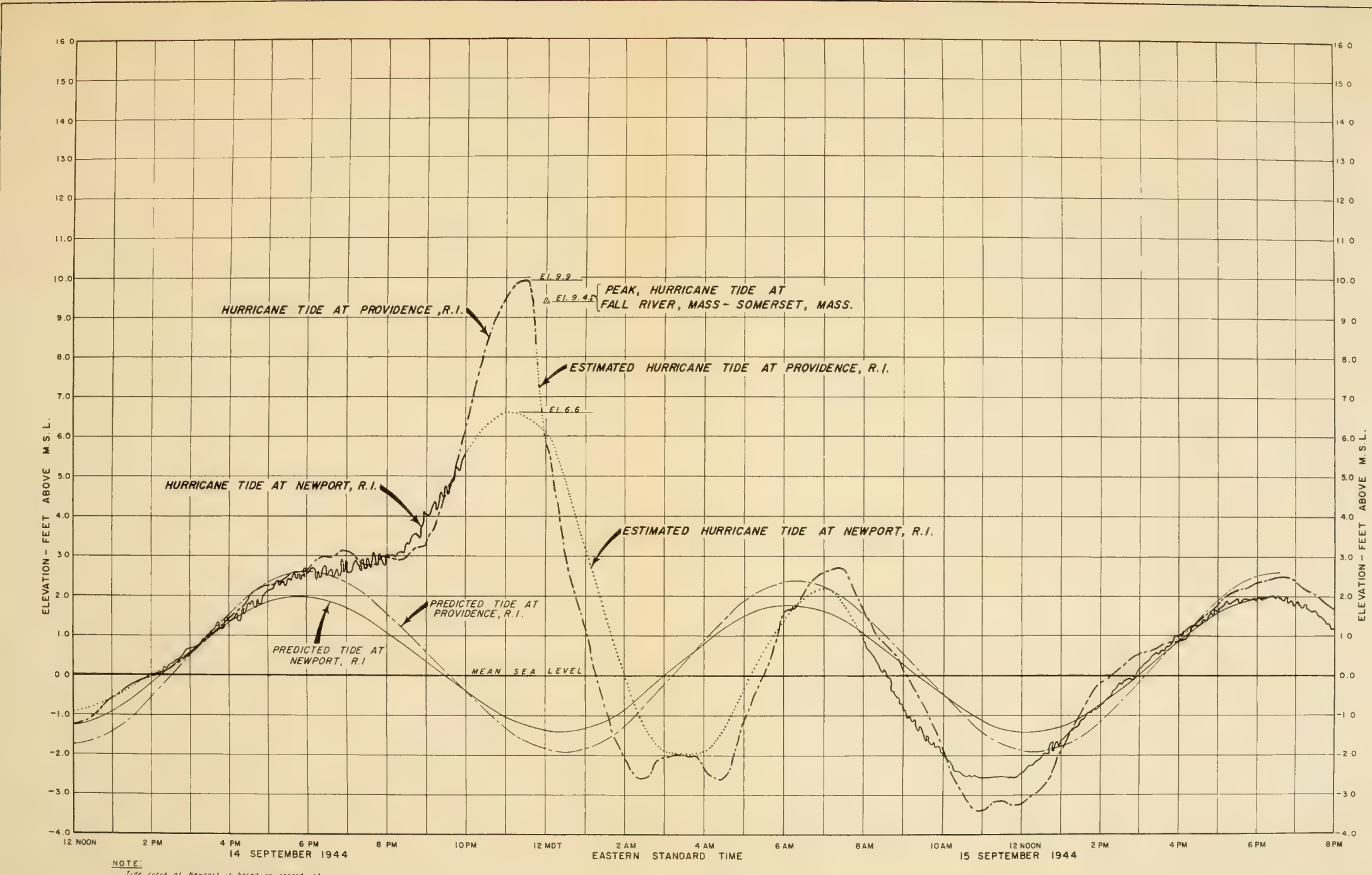

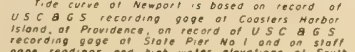

NARRAGANESURVEY

TIOE CURVES HURRICANE OF 14-15 SEPTTMERR

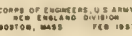





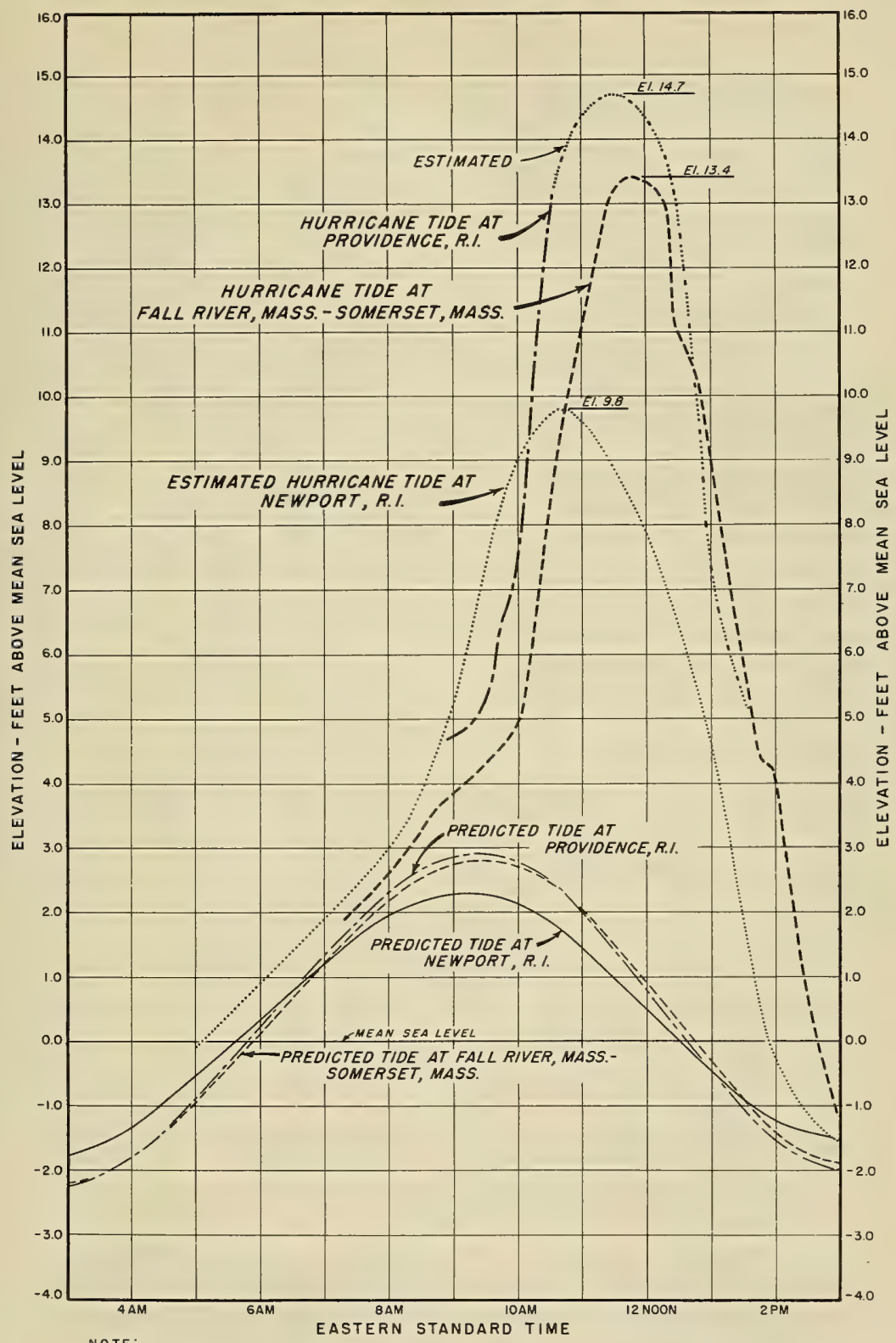

NOTE:

on observed high of Nater elevolions. Tide

curve of providence is based on abserved

high water elevations and stoff goge

HURRICANE SURVEY

NARRAGANSETT BAY

RHODE ISLAND - MASSACHUSETTS

TIDE CURVES

Somerset is bosed on high wafer elevation

al Somersel Slotion, Montaup Electric Co."

HURRICANE OF 31 AUGUST 1954 



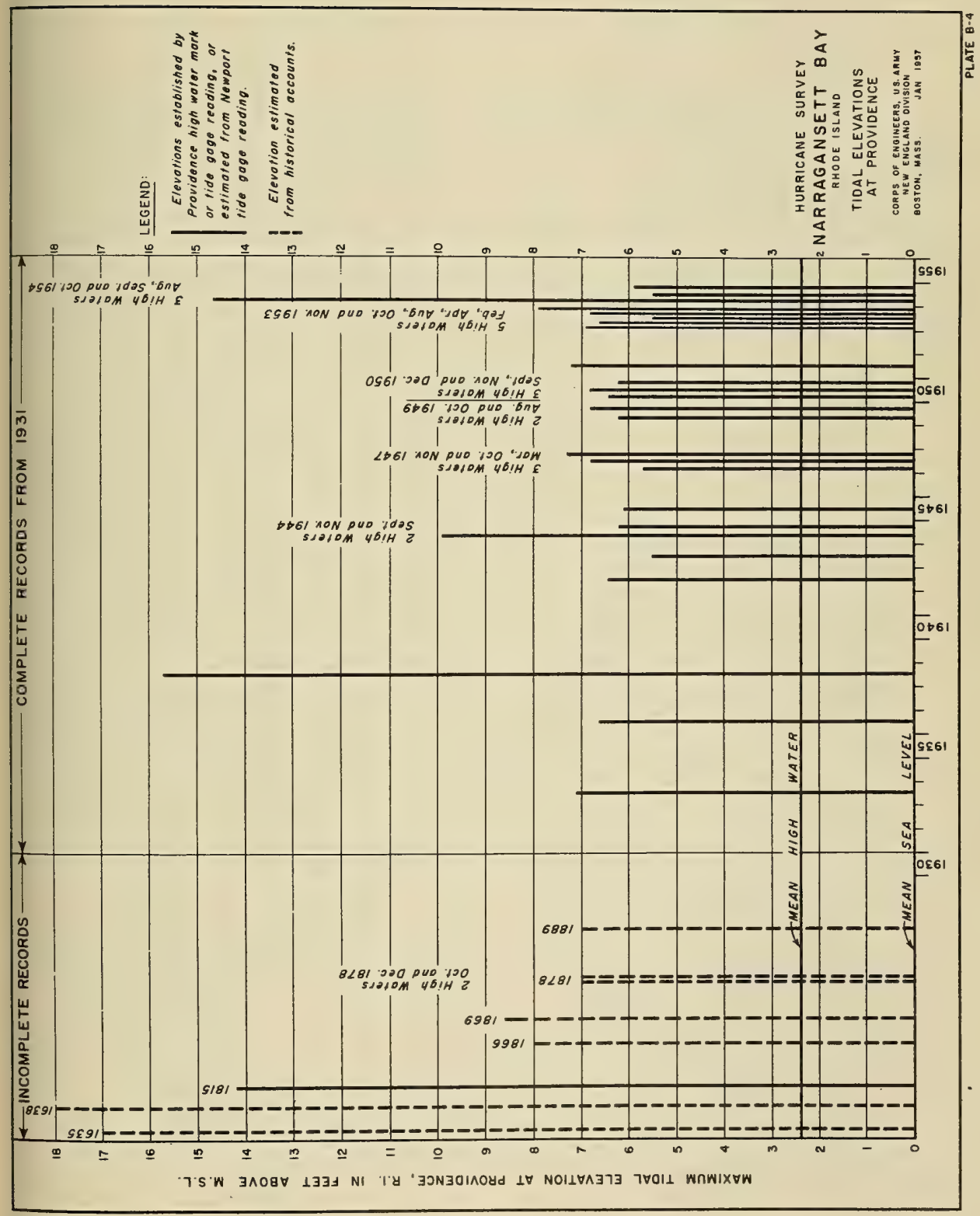





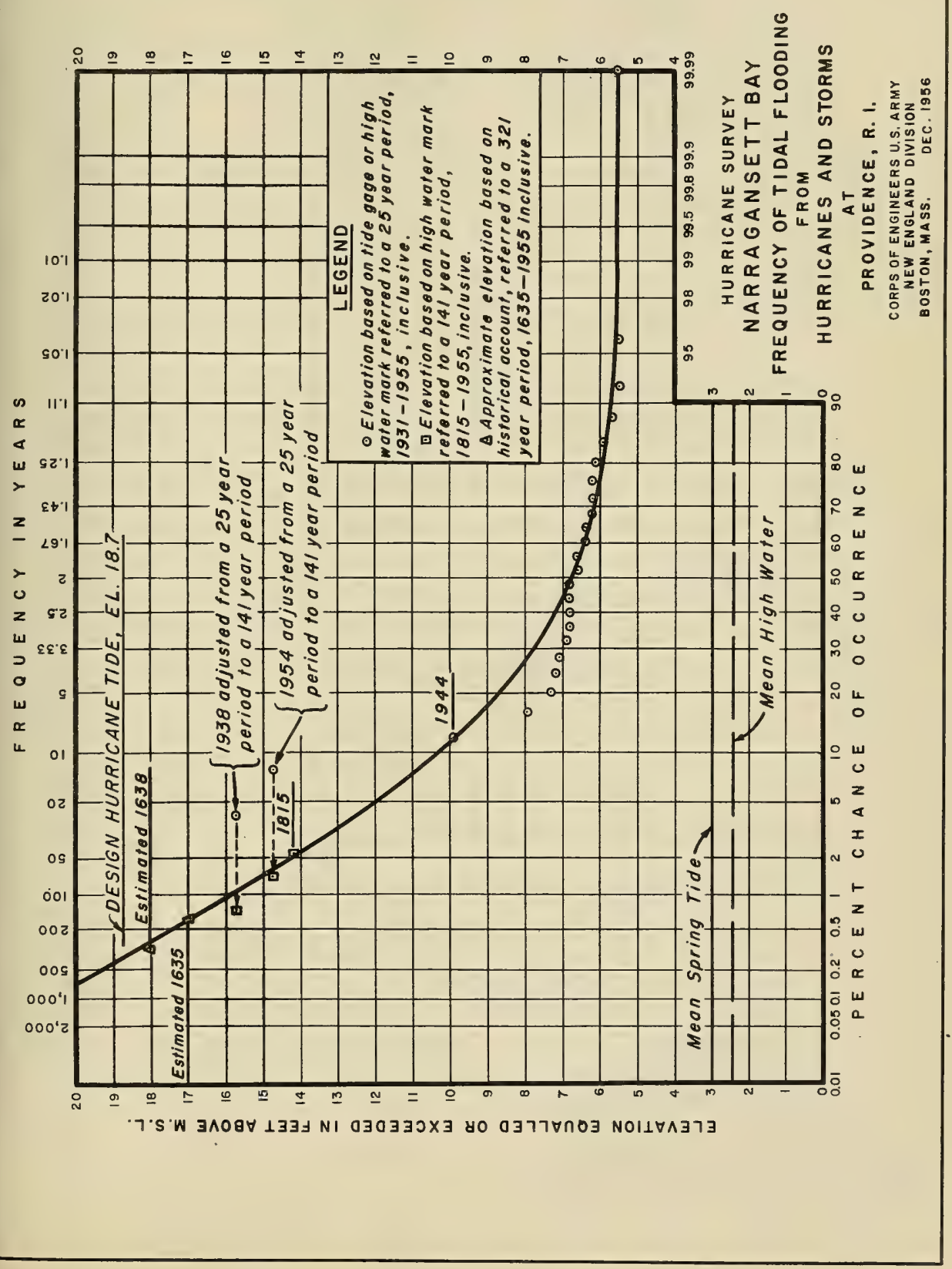





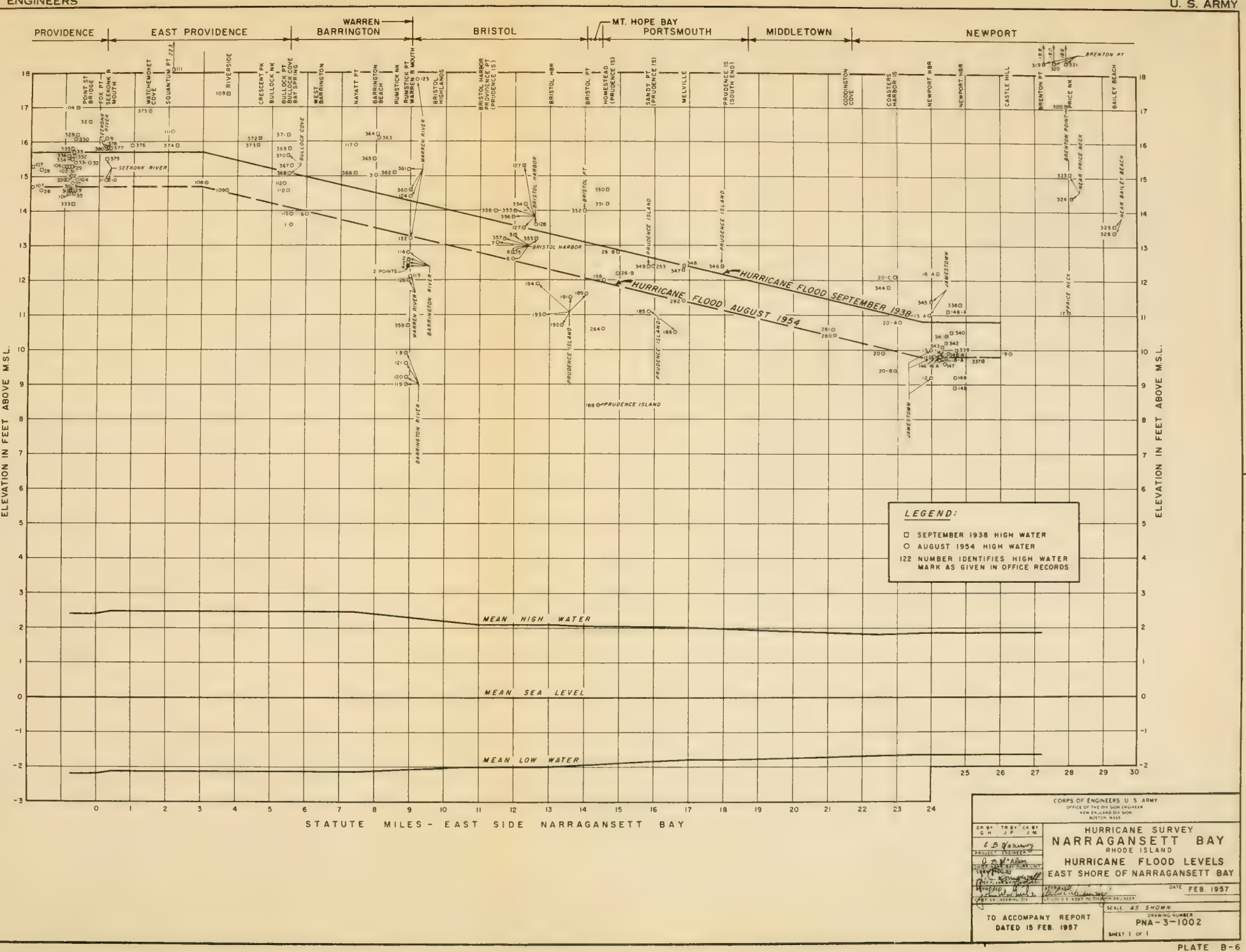





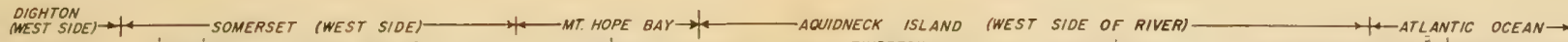

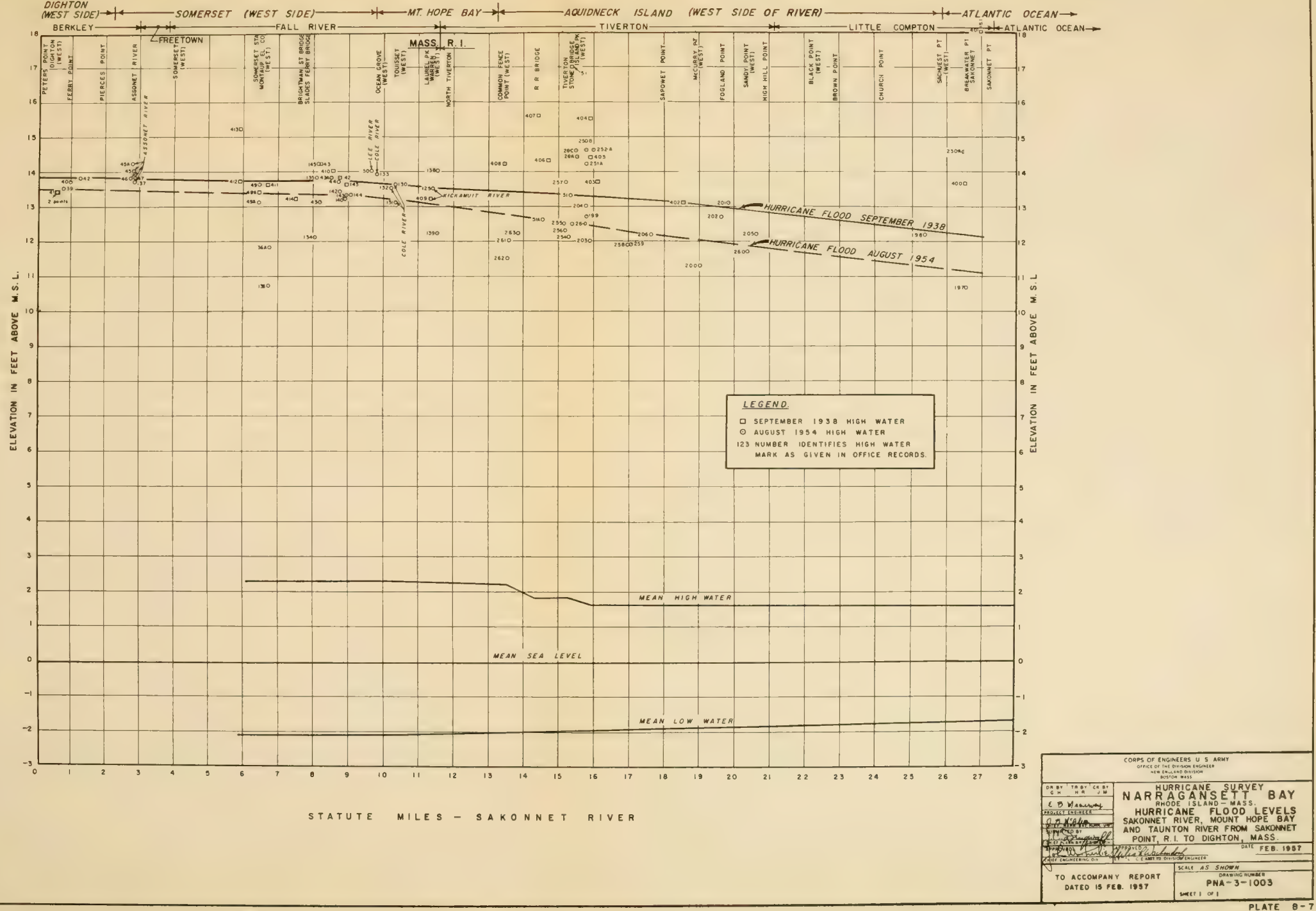





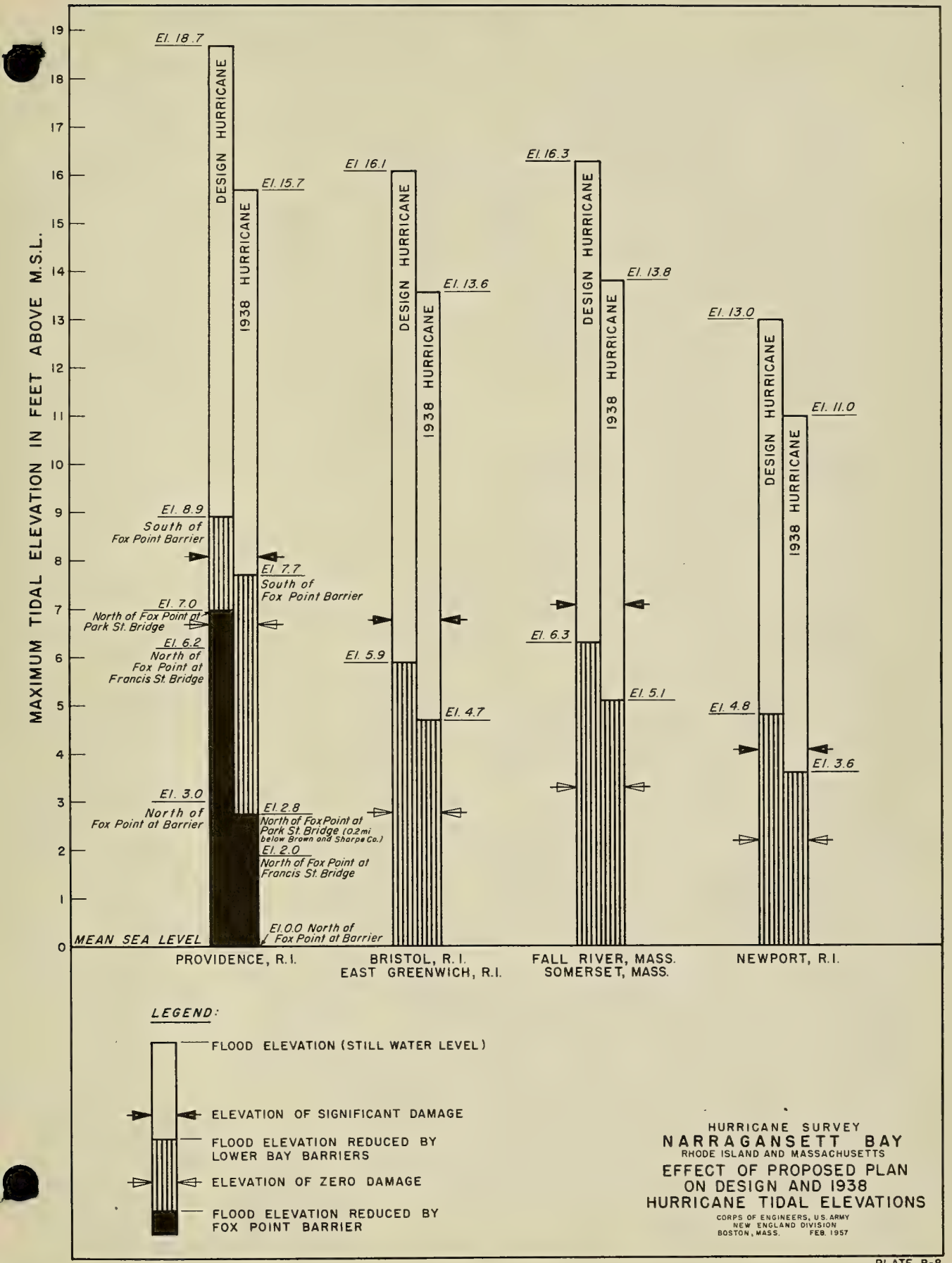



APPENDIX C

HYDROLOGY AND STREAMFLOW 



\section{APPENDIX C \\ HYDROLOGY AND STREAM FLON}

\section{C-1. INTRODUCTION}

This appendix presents data to supplement the sections of the main report relating to the subjects of hydrology and stream flow. It includes a sumary of temperature and precipitation data to amplify the section of the report on "Climatology", a summary of stream flow coincident with hurricane tidal flooding, the transposed September 1938 storm, the hydrologic possibilities with the 1938 hurricane centered over the Woonasquatucket and loshassuck Rivers, and the Blackstone River, and design stream flow to amplify the section on "Design Hurricane Tidal Flood".

\section{C-2. TEMTPERATURE AND PRECIPITATION}

The variable and temperate climate of the Narragansett Bay area is influenced by several meteorological factors which produce extremes of temperature and precipitation. The area lies in the path of the "prevailing westerlies" and the cyclonic disturbances that cross the country from the west and southwest. It is also exposed to occasional coastal storms that move up the Atlantic seaboard, some of which are of tropical origin. Significant temperature and precipitation data taken from the United States Weather Bureau Station, Providence, Rhode Island, for the fiftyyear period of record, including 1954 are summarized in Table C-I. 
TABLE C-1

TEMPFRATURE AND PRECIPITATION

AT PROVIDENCE, RHODE ISLAND

$(1904-1954)$

(Degrees Fahrenheit)

\begin{tabular}{|c|c|c|c|c|c|c|}
\hline Month & Mean & Maximum & Minimum & Mean & Maximum & Minimum \\
\hline January & 29.9 & 68 & -9 & 3.69 & 7.12 & 1.35 \\
\hline Eebruary & 29.4 & 69 & -17 & 3.04 & 5.80 & 1.18 \\
\hline March & 37.9 & 90 & 2 & 3.57 & 8.31 & 0.07 \\
\hline April & 47.6 & 91 & 11 & 3.47 & 6.70 & 0.72 \\
\hline May & 51.8 & 95 & 32 & 3.13 & 9.25 & 0.57 \\
\hline June & 67.0 & 101 & 39 & 2.94 & 7.21 & 0.04 \\
\hline Juzy & 72.8 & 101 & 49 & 2.06 & 6.92 & 0.24 \\
\hline Aurust & 70.9 & 102 & $\psi_{4}$ & 3.65 & 12.24 & 0.78 \\
\hline September & 64.0 & 99 & 33 & 3.19 & 9.79 & 0.48 \\
\hline October & 54.2 & 90 & 25 & 2.83 & 5.45 & 0.15 \\
\hline November & 43.3 & 82 & 9 & 3.51 & 8.50 & 0.31 \\
\hline December & 32.9 & 68 & -12 & 3.56 & 9.44 & 1.05 \\
\hline innual & 50.6 & 102 & -17 & 39.64 & 58.57 & 29.50 \\
\hline
\end{tabular}

O-3. BUTOFT AND STREALI FLOW

Recoras of the streari flow for the four river basins in the Narragansett ay area have been obtained by the U. S. Geological Survey for various periods of time since February 1929. The largest basin is the Taunton River Easin with a drainage area of 550 square miles, including Watappa Pond. The next largest is the Blackstone River Basin with a 539 square mile watershed. The Pawtuxet River Basin has a orainage area of 230 square miles, and the woonasquatucket and loshassuck drain a combined area of 76.1 square miles at their confluence, in the center of Providence. A summary of the stream flow at II U.S.G.S. gaging stations is contained in Table $\mathrm{C}-2$. 


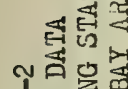

号

उ命 욉보엉

स्में

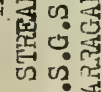

D究

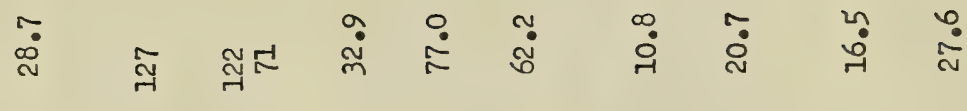

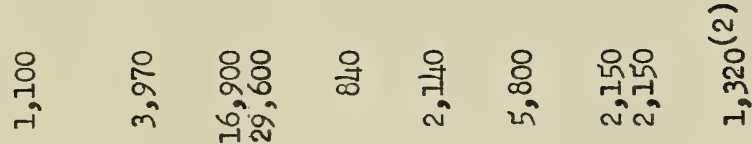

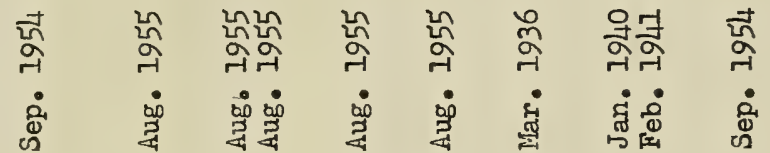

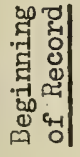

न्ने

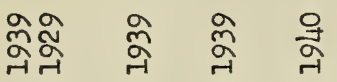

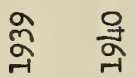

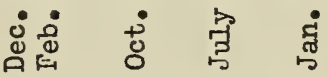

:

E⿺

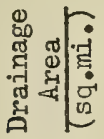

m.

mi

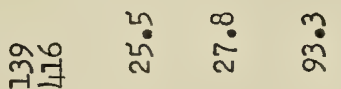

요 m

8

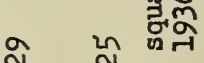

今

+艹

अ न्तु

․

द्व

용

ต ฐ్

망

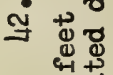

o. 또

न्तु

है जै

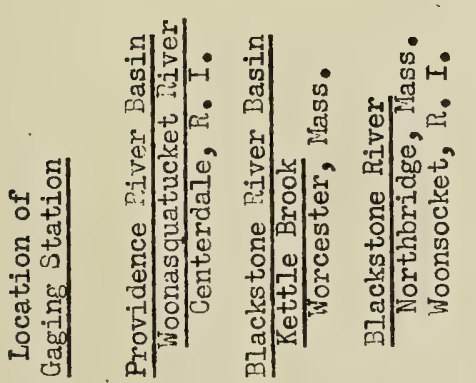

(1)

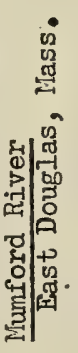

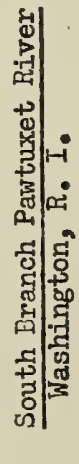

تี0 
Heavy precipitation, often of torrential proportions, usually accompanies a hurricane and in many cases will arrive several days in advance. Pre-hurricane rainfall is produced when varm moist air, circulating around the eastern or northern side of a hurricane, collides with the cold air along a far-cistant, pre-existing front. The September 1938 storm, wherein the greatest part of the rainfall occurred during the four day period before the hurricane crossed the coast of Connecticut, is an example of pre-hurricane precipitation. Approximately 90 percent of the rainfali at Providence was pre-hurricane rainfall. An example of high rainfall irmediately accompanying a hurricane is the September 1944 hurricane (see Table C-3). Other examples of hurricane rainfall which occurred coincident with the hurricane itself are those of September 1954 (Edna) and August 1955 (Diane).

\section{TABIE C-3}

HURZI SANE RAIIFALE

MAZTZAGATSETT FHY IIFEA

\begin{tabular}{|c|c|c|c|c|c|c|c|c|}
\hline \multirow[b]{2}{*}{ Hurricane } & \multicolumn{2}{|c|}{ Providence, R.I. } & \multicolumn{2}{|c|}{ Fall River, liass. } & \multicolumn{2}{|c|}{ Taunton, Mass. } & \multicolumn{2}{|c|}{ Worcester, Ilass, } \\
\hline & $\begin{array}{l}\text { Tlax. } \\
24 \text {-ir }\end{array}$ & Total & 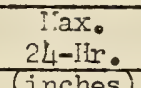 & Total & $24-\mathrm{Hr}$ & Total & $\begin{array}{l}\text { Max. } \\
24-\mathrm{Hr} .\end{array}$ & Total \\
\hline $\begin{array}{l}\text { Sept. } 1938 \\
\text { Sept. } 1944\end{array}$ & $\begin{array}{l}1.0 \\
5.7\end{array}$ & $\begin{array}{l}3.1 \\
8.4\end{array}$ & $\begin{array}{l}1.7 \\
3.6\end{array}$ & $\begin{array}{l}4.2 \\
5.8\end{array}$ & $\begin{array}{l}1.4 \\
3.2\end{array}$ & $\begin{array}{l}3.7 \\
8.2\end{array}$ & $\begin{array}{l}3.4 \\
2.7\end{array}$ & $\begin{array}{l}8.4 \\
4.5\end{array}$ \\
\hline $\begin{array}{l}\text { (Carol) } \\
\text { Sent. } 1954\end{array}$ & 2.8 & 2.8 & 2.3 & 2.4 & 2.4 & 2.4 & 5.1 & 5.1 \\
\hline (Edna) & 4.4 & 4.4 & 4.2 & 4.4 & 4.0 & 5.2 & 6.1 & 6.4 \\
\hline (Diane) & 5.5 & 6.1 & 3.8 & 4.7 & 6.2 & 10.3 & 7.7 & 12.5 \\
\hline
\end{tabular}

C-5. HUREICARTE RUNOFF

The majority of the record floods in this area have resulted from hurricane rainfall. The heavy precipitation that generally accompanies a hurricane has been the cause of numerous local flash floods, and has also produced severe flooding on many of the large river basins when following a lons period of antecedent precipitation. A brief description of recent hurricane river flooding in the Narragansett Bay area is given in the following paragrapins and summarized in Table $\mathrm{C}-4$. 
a. September 1938 Flood. From the 12th to the 16th of September many sections of New England had been saturated by as much as four inches of rainfall, with comparatively little surface runoff. Precipitation commenced again on the 17 th and increased in intensity until the 2lst when the heavy hurricane rainfall arrived. Although Providence recorded only 3.1 inches of rain during this period, a peak of about 17 inches fell in both Connecticut and Massachusetts (Plate $\mathrm{C}-2$ ). Had this storm been centered over the Narragansett Bay area, major river flooding would have occurred and added more damage and destruction to that already caused by the wind and tidal flooding.

b. September 11, 1954 Flood (Edna). The rainfall associated with this hurricane amounted to about 4.4 inches at Providence and 6.3 inches at Woonsocket. A total of 8.7 inches fell in about 15 hours at Quonset Point, Rhode Island. There was little antecedent precipitation, but the high concentration of rainfall in a short period of time produced serious flooding on many streams in Rhode Island. This flood was the maximum of record for the Woonasquatucket River and the second highest for the Pawtuxet River (see Table C-4).

c. August 19, 1955 Flood (Diane). Torrential rains accompanied this hurricane, falling on ground already saturated by the heavy precipitation which accompanied Hurricane Connie during the previous week (August 11-15). In a two-day period over six inches of rain fell in Providence and 10.4 inches in Woonsocket. This rainfall caused a devastating flood in Woonsocket and the maximum flood of record on the Blackstone and Taunton Rivers (see Table (C-4).

\section{C-6. DRSIGN STORMI}

The September 1938 storm, which produced the highest amount of rainfall associated with a damaging hurricane from tidal flooding in southern New England, was adopted as the design storm. The hurricane of August 31, 1954, which was a rapidly moving storm, did not bring extremely heavy precipitation to southern New England but caused excessive tidal flooding in the Narragansett Bay area. Ifurricane Diane of August 19, 1955, which was a slow moving storm, produced record rainfall in parts of Connecticut and lassachusetts near the Narragansett Bay area, although the winds were not of hurricane intensity coincident with the record rainfall. It has, therefore, been determined that it would not be consistent with design based on probable occurrence to combine the maximum rainfall associated with the August 19, 1955 storm and the tidal flooding associated with the September 21, 1938 storm. Therefore, the September 1938 storm was adopted for use in determining the 
maximum probable runoff from the streams tributary to Narragansett Bay. A hyc'rologic study of the August 1955 storm, transposed over the Narragansett Nay area, was made to compare the runoff from a storm producing excessive rainfall but not occurring coincident with tidal flooding. The results of this study are summarized in Table C-4.

The maximum precipitation for the September 1938 storm was concentrated over Portland (Buck), Connecticut, about one mile north of "iddletown, where a total of 17 inches was recorded for the period Sentember 17-21. This storm was transposed over the Narragansett Eay area as studies by the $\mathrm{U}$. S. Weather Bureau indicate it could as easily have been located there.

\section{C-7. DESIGN FLOOD FOR FOX POINT BARRIER}

For the Fox Point Barrier, the September 1938 storm was centered over the Woonasquatucket and Ioshassuck Rivers to produce the maximum amount of runoff at tis point. The rainfall distribution was based on the Corps of Engineers' "Maximum Average Depth-Duration of Rainfall" for New England over a drainage area of 100 square miles (Plate C-3). The total accurnulative rainfall for a 24 -hour period was 9.5 inches. An infiltration rate of 0.2 inches per hour was used for mural areas and 0.1 inches per hour for city drainage. Unit hydrographs were developed for each river. The inflow hydrograph for the transposed September 1938 storm at Fox Point, including the contributions from the Woonasquatucket and Noshassuck Rivers and the "local" area is shown on Plate $\mathrm{C}-5$.

‥ Woonasquatucket River. The Noonasquatucket River, with a drainage area of 52.3 square miles, was divided into three areas: (I) the 24.5 square mile ansa above the Woonasquatucket Reservoir at Iymansvilie, Riocle Island, (2) the 20.5 square mile area between the dam and the city limits of Providence, and (3) the 7.3 square mile city area. The peak runoff from the reservoir was assumed to be 100 cubic feet per second per square nile. To estimate the minoff from the 20.5 square mile area, a 3-hour unit graph was developed from the September 1954 flood (the flood of record for this stream) based on the runoff between the reservoir and the U. S. Geolorical jurvey gaging station at Centerdale, Rhode Island (drainage area $=38.3$ square miles). The unit graph for the city area was computed synthetically, using Snyder's coefficients. The rainfall excess for the September 1938 storm was arranged to give the maximum peal discharge when applied to the composite unit hydrograph of the Woonasquatucket River at its mouth (see Table (-4). 
b. "oshassuck River. The discharge from the Moshassuck River (drainage area $=23.8$ square miles) for the transposed September 1938 flood was obtained in the same manner as for the woonascuatucket River. The basin was divided into three areas: (1) the three-scuare mile city area, (2) the Moshassuck River (drainage area $=10.1$ scuare miles), and (3) its tributary, the West River (drainage area $=10.7$ square miles), above the city limits. Due to a lack of stream flow records in this basin, no separate unit hydrographs were developed for either the Moshassuck River or the West Iiiver. The unit graph developed for the Woonasquatucket River at Centerdale was used to derive the munoff for both the Moshassuck and West Rivers at the city limits. The rainfall, runoff and discharge values obtained in this study are summarized in Table $\mathrm{C}-4$.

\section{C-8. DESIGN FLOOD FOR LONER BAY BARRIERS}

For the hurricane protection studies at the Lower Bay Barriers, as well as the preliminary investigations at the Fields Point, Conimicut Point, the Middle Bay sites, the transposed September 1938 storm was centered over the Blackstone River. The rainfall distribution was based on the Corps of Engineers' "Maximum Average Depth-Duration of Rainfall" for New England over a drainage area af 500 square miles. The residual rainfall was applied to the other basins and to the "local" areas. The total accumulative rainfall for the 500-square-mile area amounted to 14.2 inches for a 72-hour period and the residual rainfall was 13.0 inches. The inflow hydrograph at the Lower Bay site, including the contributions from the various rivers and "local" areas, is shown on Plate $\mathrm{C}-6$.

\section{a. Elackstone River. This river, with a drainage area} of 539 square miles, flows into the Providence River just below Fox Point. A 6-hour unit hydrograph was developed based on floods of record at the U.S. Geological Survey gaging station at Woonsocket, Rhode Island (drainage area $=416$ square miles). This unit graph vas routed to the mouth of the river, using a 6-hour lag. Separate 6-hour unit graphs were developed synthetically for the Ten Iille River (drainage area $=57.6$ square miles) and the local area between Woonsocket and the mouth of the Blackstone River (drainage area $=65.4$ square miles). The three unit graphs were added to give a total 6-hour unit hydrograph at the mouth. An infiltration rate of 0.1 inch per hour was used and the rainfall excess applied to the unit hydrograph to obtain the maximum discharge. The results of this computation are included in Table $\mathrm{C}-4$. 
L. Woonasouatucket and Ioshassuck Rivers. The 3-hour unit hydrographs that were developed for these rivers were converted to 6hour unit granhs and combined. The residual rainfall of 13.0 inches was applied to this, then added to the runolf from the area above the Woonasquatucket ireservoir. The resulting hycirosraph had a peak discharge of 7,800 cubic feet per second and a volume of 6.4 inches of minoff (see Table C-4).

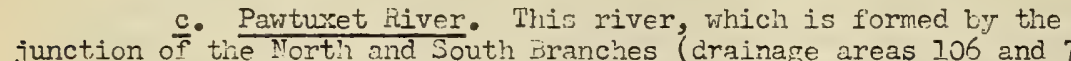
square miles, respectively) in West Jarick, Fhode Island, has a total watershed area of 230 square miles. The munoff from the North Branch is controlled by the Scituate Reservoir, the water supply for the City of Providence. The runoff fror the South Branch is partially controlleci by the Hat River Reservoir. Two U. S. Geolouical Survey gaging stations are located in the basin, one on the South Branch at Washington, Rhode Island (arainage area $=63 . \varepsilon$ square miles), and the other at Cranston, Rhode Island (drainage area $=200$ square miles, ) on the main river. A 6-hour unit hydrograph for the Pawtuxet River at Cranston was develoned from the September 1954 and October 1955 floods, and from the discierge recorcis obtained from the scituate and Flat River Reservoirs. 'The 6-iour innit hydrograph at the mouth of the Pawtuxet iiver was. obtained from the uranston unit sraph by increasing the volume to give one inch of minofi from the total drainage area. No lag was used for the $L .5$ mile reach between the gage and the mouth as it was assumed that it would be offset by the local munof. I"ie rainfall distribution for the transposed jeptemher 1938 flood, using the Corps of Engineers' design criteria, was the residual rainfall depending on the location at winich the total munoff was desired, i.e., at Conimicut Point, or for the lifidle or Lower Bay. In each case, the storm was considered to be centered over the Blackstone River Easin. For Conimicut Point, therefore, the residual rainfall ( 13.5 inches occurring in a 72 -hour period) was applied to the drainage areas with a combined area of 370 square niles. For the Middle and Lower Bay sites, the accumulative rainfall amounted to 13.0 inches over an area of 1,250 square miles. The rainfall excess was applied to the unit hydrograph after deducting the infiltration at a rate of 0.1 inch per hour (see Table $\mathrm{C}-4$ ).

d. Taunton River. This river, with a drainage area of 550 square miles, including Watuppa Pond, flows in a general southerly direction into Mount Hope Bay opposite Fall River, Massachusetts. Its principal tributary is the Three Nile River, which drains 85.5 square miles. There is a U.S. Geological Survey gaging station on the main river at State Farm, Massachusetts (drainage area $=260$ square miles), and on the wading iiver, a tributary of the lihree 
Mile River, near Norton, Nassachusetts (drainage area $=42.4$ square miles). A 6-hour unit hydrograph at State Farm was developed from the August and October 1955 floods and routed to the mouth. The observed October 1955 rlood was used for the Wading River at Norton, doubled, lagged four hours, and assumed to represent the runoff from the Three Mile River at its mouth. The 6-hour unit sraph obtained from this flood was routed to the mouth of the Taunton River, with a las of three hours. By using a straight drainage area relationship, the unit graph for the 185-square-mile uncontrolled drainage area was computed from the unit graph at State Farm. The components of the three computed hydrographs were added together and adjusted. The same residual rainfall excess that was used for the Pawtuxet River was applied to the Taunton River unit graph (see Table C-4).

\section{C-9. DESIGN STREAM FLOW}

The design stream flows obtained from the studies of the transposed September 1938 storm are discussed in the following paragraphs for the Fox Point and Lower Bay Barrier sites.

a. Fox Point Barrier. The peak fresh water inflow at this location is 9,200 cubic feet ner seond, of which 5,350 cubic feet per second is contributed by the Woonasquatucket River, 3,700 cubic feet per second by the lioshassuck River and 100 cubic feet per second by the area below the confluence of these two rivers in Providence (see Plate C-5 and Table C-4). This latter area has a maximum discharge of 600 cubic feet per second, but the discharge reaches its peak approximately nine hours before the total inflow. Some local flooding will occur on the Woonasquatucket River above Eagle Street near such places as the U.S. Rubber Company, the Queen Dying Company, and in the vicinity of the business area of Clneyvilie for discharges in excess of 1,500 cubic feet per second. However, below this point the flood flows will return to the confines of the river before reaching the downtown business area of Providence. For the Moshassuck River, some flooding will occur above Randall Street (about 0.8 mile above its mouth) for flows greater than l,200 c.f.s. Considerable flooding will be experienced for discharges in excess of 3,600 c.f.s. above Smith Street ( 0.3 mile above the mouth).

The total volume of runoff at Fox Point is about 21,000 acre-feet, or 5.1 inches of runoff from the 77 square miles of drainage area. The storage available above the barrier is less than 950 acre-feet at elevation $6.5 \mathrm{~m} . \mathrm{s} .1$. (approximate elevation 
of zero damage in Providence). To prevent flooding of Providence, a pumping station is incomorated in the design of the barrier. The runoff vill be discharged into the bay by means of five pums with a combined capacity of 8,000 curic feet per srcrnd a.t a head of 22 feet, and a capacity of 9,200 cubic feet per second at a head of I6 feet (see Appendix G).

b. Lower Bay Earriers. The peak flow at this location is 84,000 cubic feet per second. The contributing strcams, besides the Woonasquatucket and Ioshassuck Rivers, are the Blackstone River, with a peak flow of 30,900 cubic feet per second, the Partuxet River with

a peak flow of 5,800 cubic feet per second, and the Taunton River with a peak flow of 14,700 cubic feet per second. The runoff from the remaining 235-square-mile land area and the contribution of the 119square-mile-water area are, respectively, 27,800 and 40,000 cubic feet per second. The total inflow is 720,000 acre-feet, or 7.6 inches of munoff. This runoff would cause a rise of less than 0.3 foot in the water level due to the large storage capacity of the bay and to the discharge capacity of the openings. Table $\mathrm{C}-4$ surmarizes this data, and Plate $\mathrm{C}-6$ shows the total discharge and the contribution thereto. 


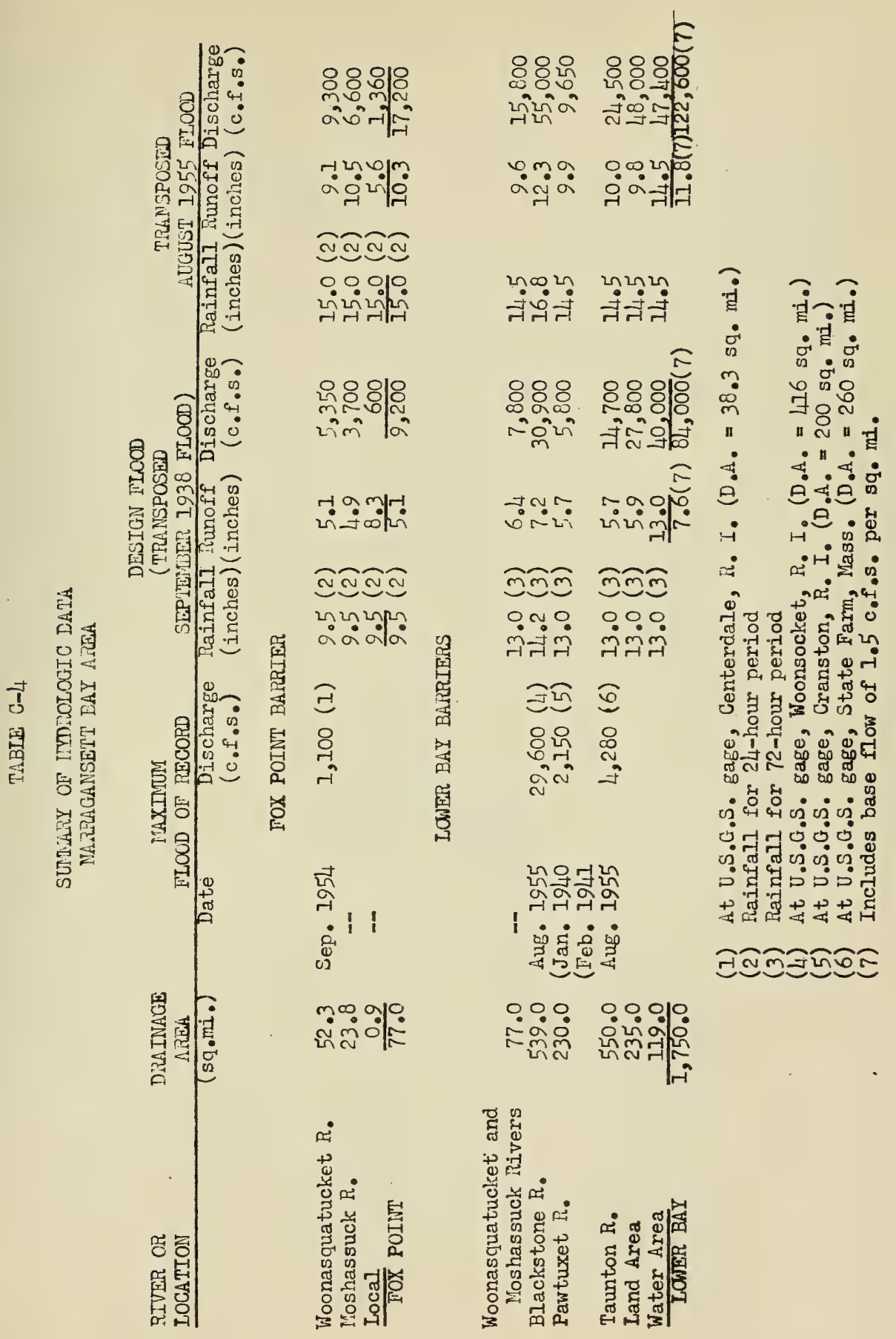





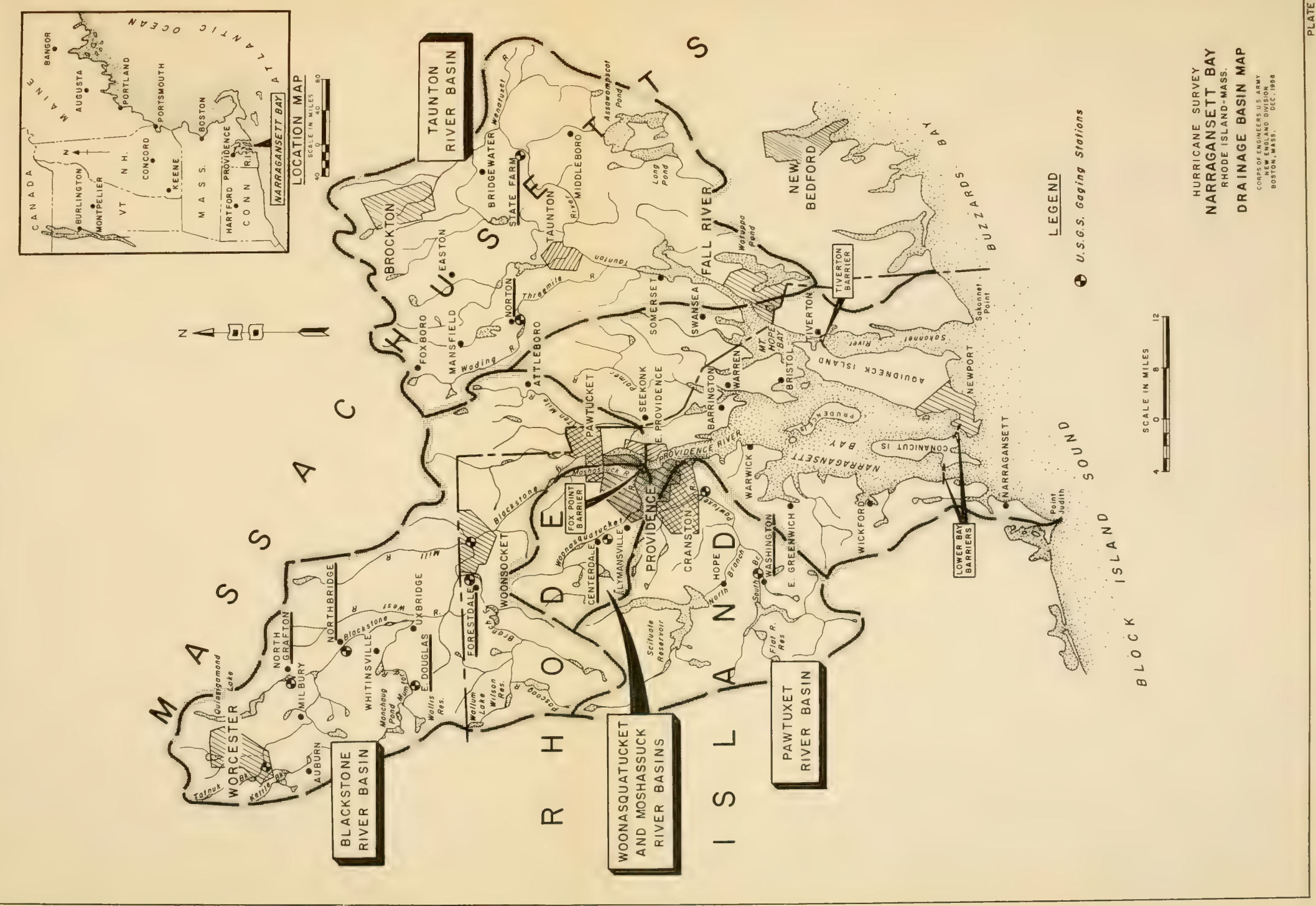





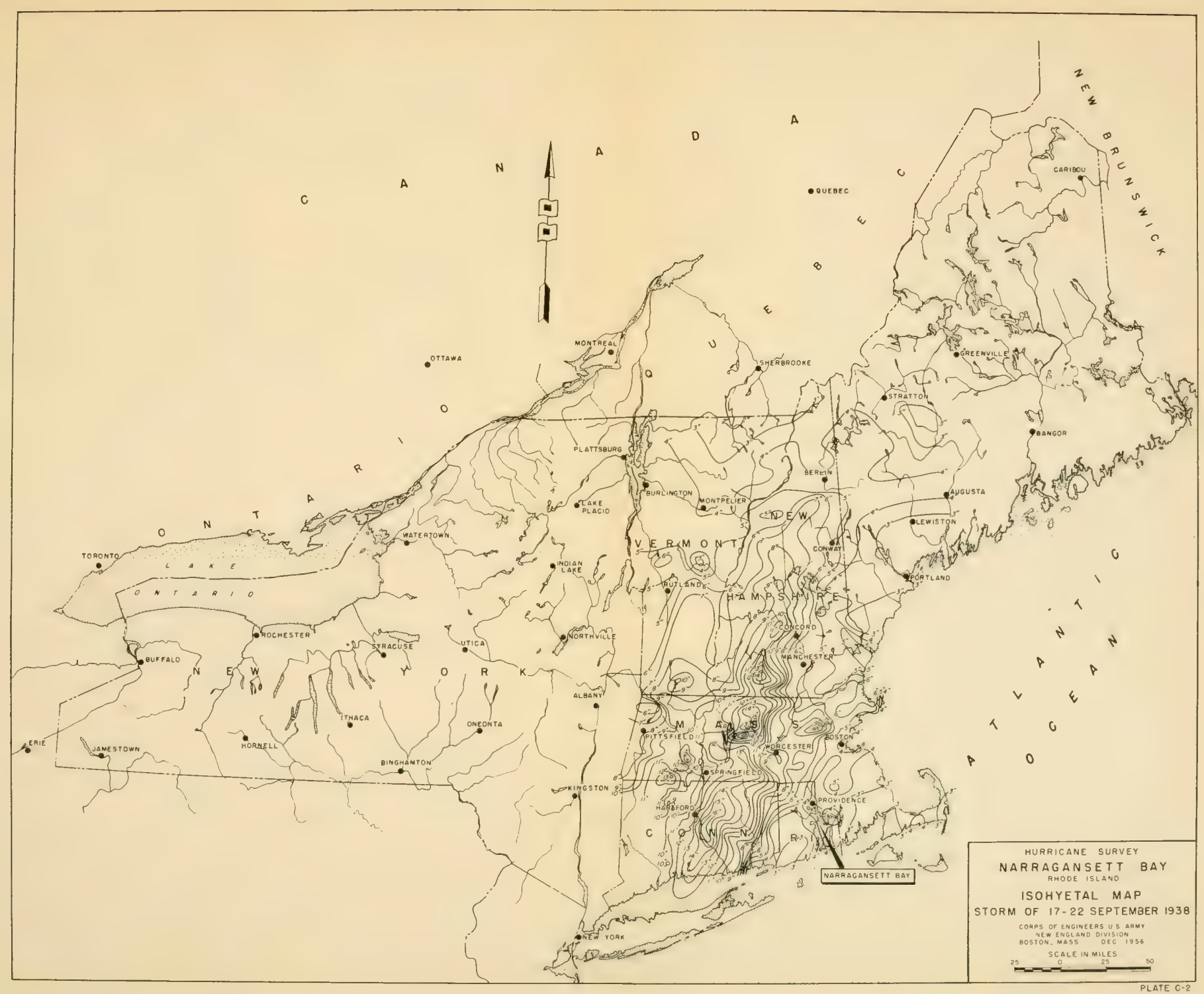




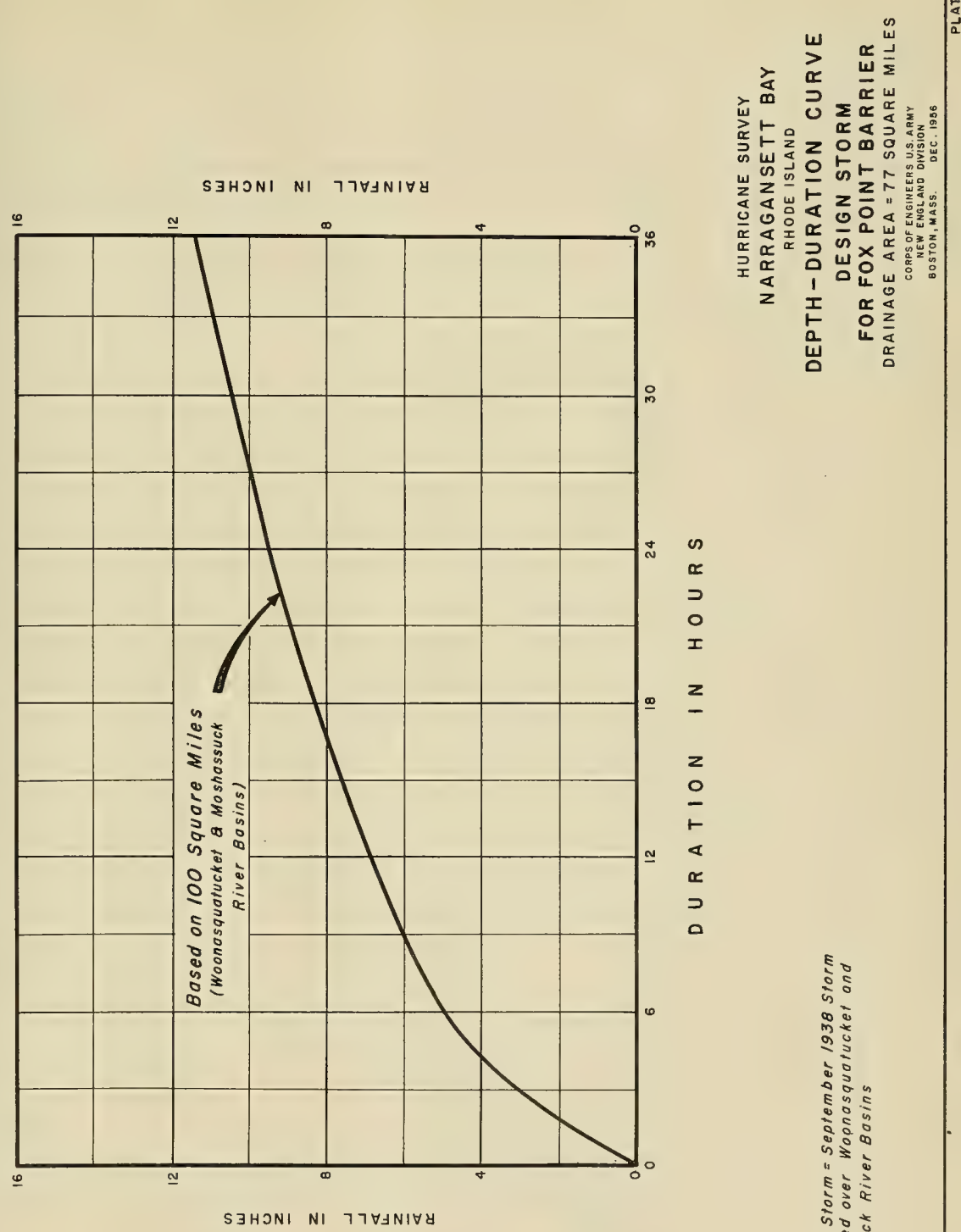

0
0
$D$
0
$I$
$z$
-
$z$
0
1
4
0
$D$
0

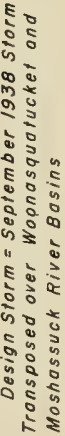





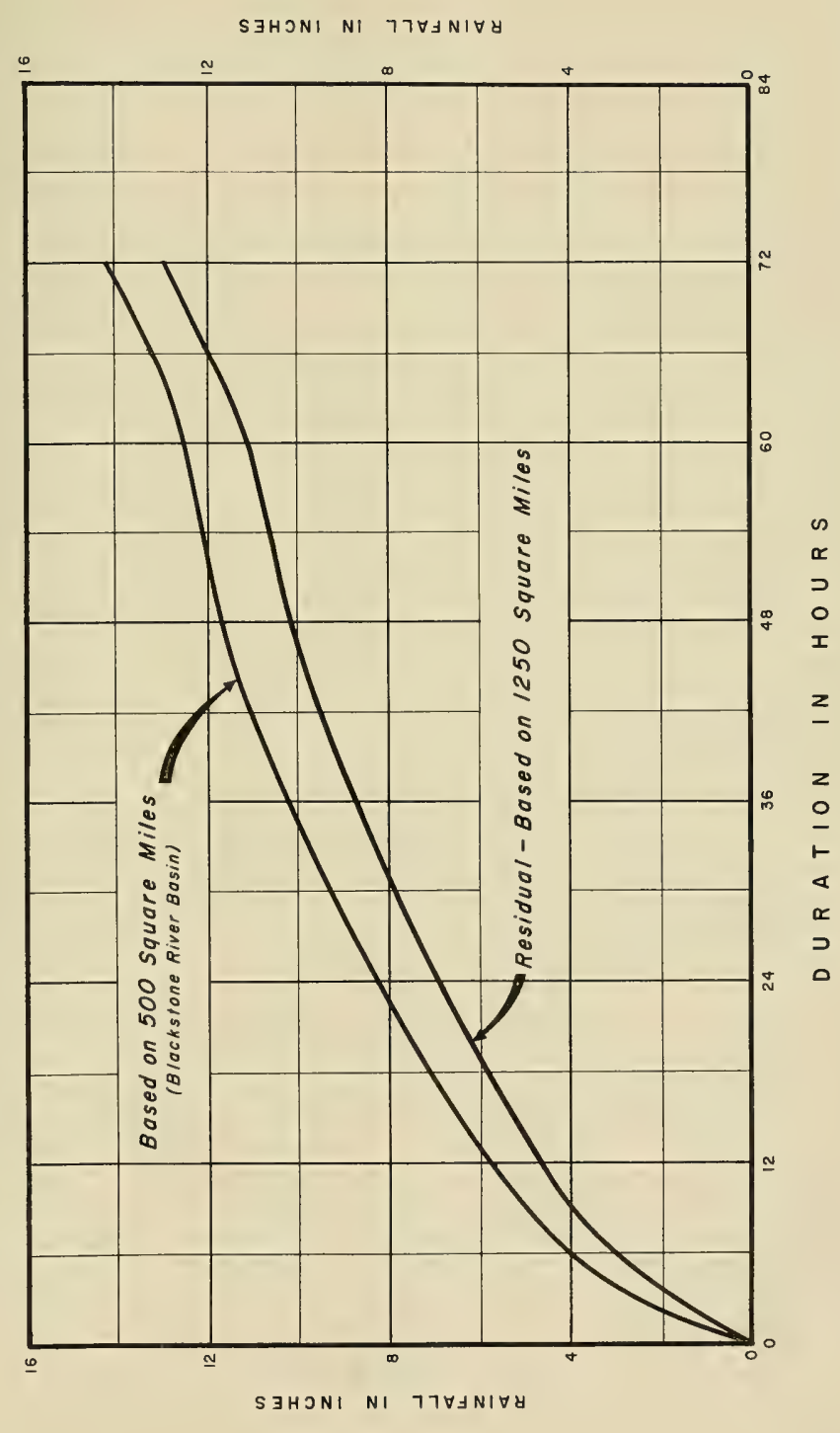

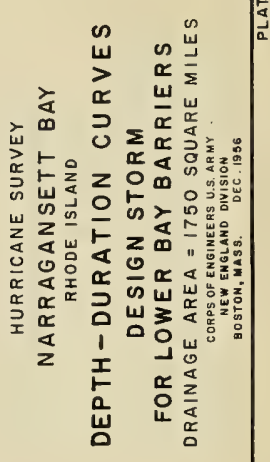

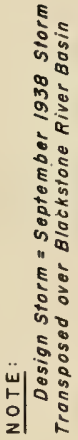





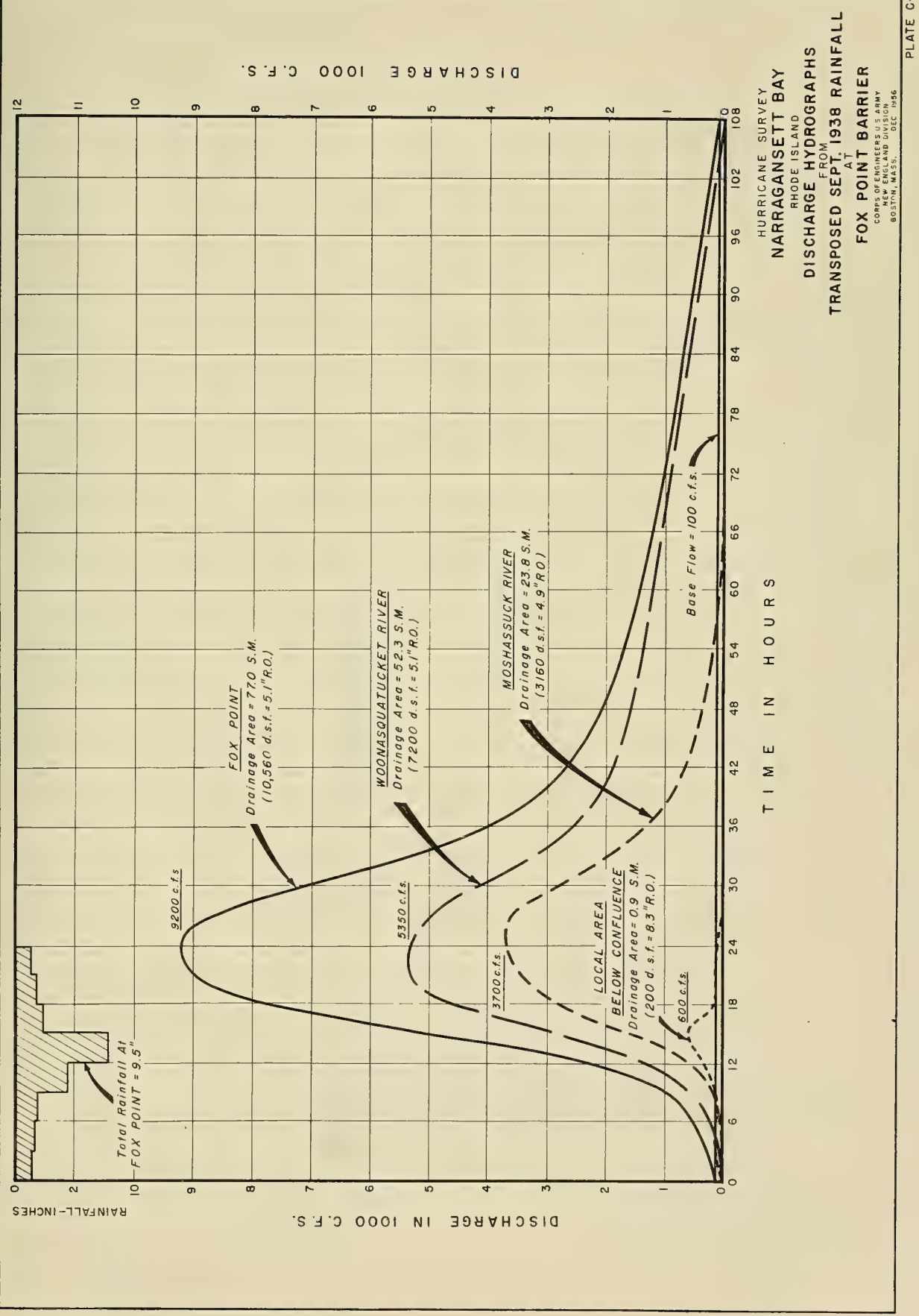





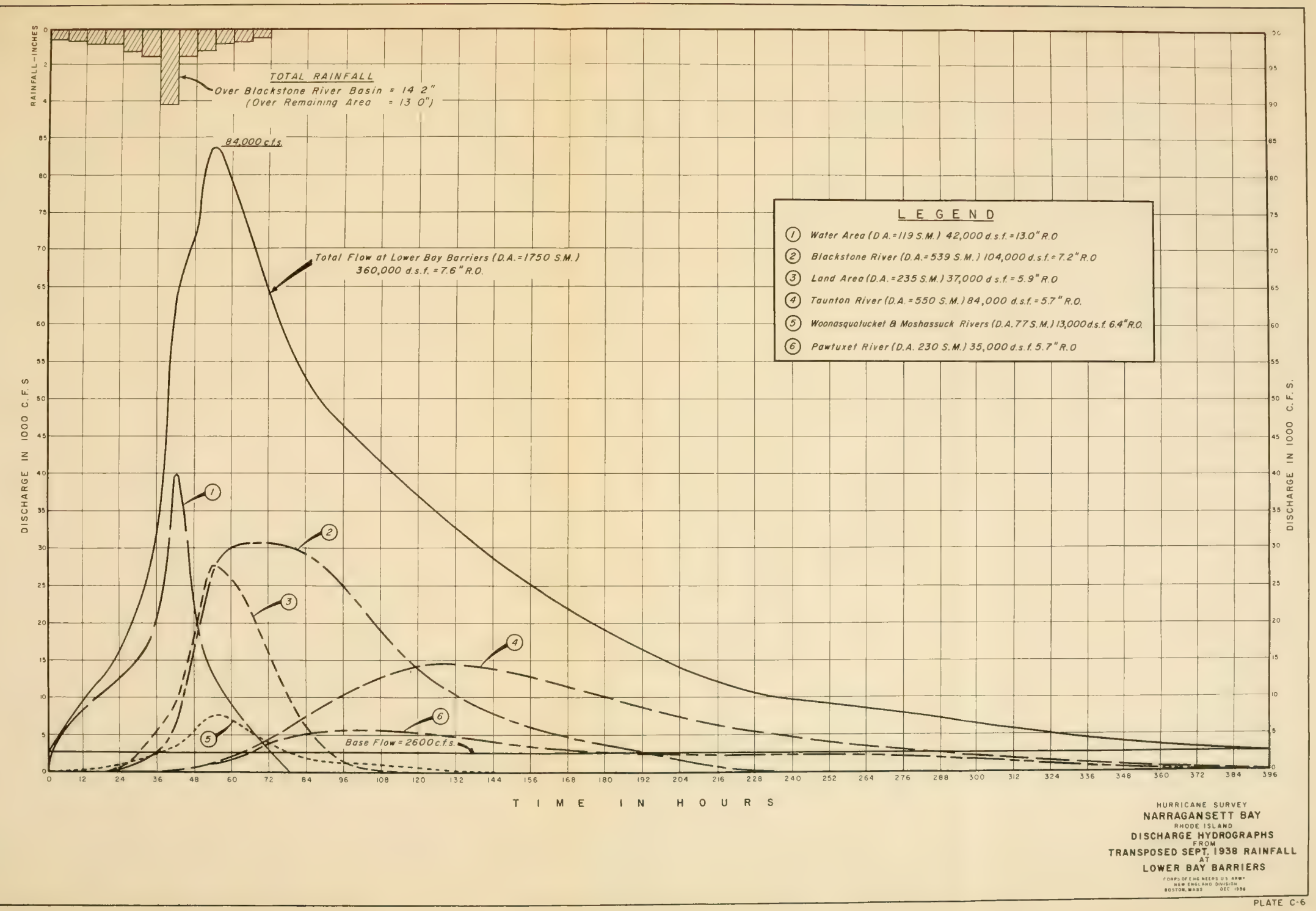



APPENDIX D

FLOOD LOSSES AND BENEFITS 



\title{
APPENDTX D
}

\section{FLOOD LOSSES AND BENEFT TS}

\author{
NAPRAGA NSETT BAY
}

RHODE ISLAND-MASSACHUSETTS

\section{D-1. MEASURFMENT OF FLOOD DAMAGES}

a. Damage surveys. Damage-surveys were initiated in the Narrangansett Bay area in September 1955 to obtain data for economic studies of the various proposals for hurricane flood protection. Essentially, the survey was a door-to-door inspection of the hundreds of industrial, commercial, residential, and other properties affected by the flood. Information obtained included (1) the extent of the areas flooded; (2) descriptions of properties; (3) the nature and amount of damages; and (4) depths of flooding, highwater references, and relationships to prior flood stages. Estimated evaluations of damage were generally furnished by property owmers. Where these estinates appeared unrealistic, they were modified by the investigators. In those cases where owners were unable to furnish loss estimates, the investigators made the ir own evaluations. Sampling methods were employed where several residences of similar characteristics and like depth of flooding were encountered. Data for public property, ntility, highway, and railroad losses was obtained from central headquarters and applied to field information. Sufficient data was obtained to derive losses for (1) the 1954 flood stage; (2) a stage 3 feet in excess of 1954; and (3) the stage where damage begins (zero damage) referenced to the $1954 \mathrm{flood}$ level. Losses were also obtained for those stages where there was a marked increase in damages at points such as floor levels and window openings.

b. Loss classification. Flood Ioss information was recorded by type of loss and by location. The loss types used were industrial, urban (commercial, residential, public), mural, highway, railroad, and utility. The type of loss was recorded by main areas, sections, and hlocks to provide a basis for later use in stage-loss and benefit analyses. The survey followed the Narragansett Bay shoreline from Providence to Point Judith on the west and fram East Providence to Sakonnet Point on the east.

Losses evaluated in the survey were the result of tangible, primary damages. Primary losses comprise (1) physical losses such as damage to structures, machinery, stock, and cost of cleanup and repairs; and (2) non-physical losses such as unrecovered loss of 
business, wages, or production; increased cost of operation; and cost of temporary facilities.

The primary loss resulting from physical damages and a large part of the related non-physical loss were determined by direct inspection of property and evaluation of losses by the property owner and field investigators or both. The non-physical portion of the primary loss is sometimes difficult to estimate on the basis of information available at a given property. Where this condition exists, the relationship between physical and non-physical losses is based on the relationship found for similar properties in the area.

Secondary tangible losses, consisting of flood-related losses, such as loss of production and wages in areas outside the immediate flood areas, have not been determined. Intangible losses, including loss of life, health, security, and detrimental effects upon national defense, have not been monetarily evaluated.

\section{D-2. EXPERIENCED DAMAGES}

a. Tidal-flood losses. Tital flooding caused by "Hurricane Carol" of 31 August 1954 took 19 lives in Rhode Island and left in its wake a total loss of more than $\$ 92,000,000$ in the Narragansett Bay area of southern Rhode Island and Massachusetts. As in the hurricane of September 1938, which produced flood stages I foot over the 1954 crest and took an estimated 250 lives, the 1954 hurricane struck the Narragansett Bay coast at a time close to the peak of the predicted gravitational high tide. The superimposed hurricane surge produced flooding of extreme depths over extensive areas along the shoreline of the bay. Seaside resort areas and beaches were particularly hard hit. Hundreds of cottages were leveled, and waterfront facilities such as yacht clibs, piers, wharves, boathouses, and bathhouses were heavily damaged at numerous locations within the bay. Many exposed beaches were severely eroded. Huge unprotected sections of Cliff lialk at Newport were demolished by the powerful seas. Iand was cut back in some areas from 50 to 100 feet, resulting in a total loss of many acres of developed property. Five bridges sus tained heavy lamage, and 2 were completely destroyed. Damages to highways throughout the area amounted to over $\$ 1,000,000$. In the bay as a whole, along some 250 miles of exposed shoreline from Point Judith to Sakonnet Point, damages to residential and commercial property amounted to a total loss of more than $\$ 72,000,000$. The greatest concentration of damages, amounting to over 40 percent of the total urban damage in the bay, occurred in the city of Providence, when widespread areas in the downtown commercial sections of the city were flooded from 4 to 8 feet by salt water, polluted by industrial and sanitary wastes. In addition, Providence industries sustained over 
half of the $\$ 13,400,000$ industrial loss in the bay. Most of the damage to residential property occurred in the bay areas south of Providence, where the destruction of homes and cottages along the susceptible shoreline was exceptionally high. Of some 3,900 dwellings which were involved in tidal flooding, over 400 were completely destroyed. Table D-I describes the limits of damage areas and Table D-2 shows a tabulation of losses by area and type.

b. Providence, Rhode Island. The city of Providence (Area I), without exception, suffered a greater amount of concentrated damages as a result of tidal flooding than any of the communities caught in the path of "Hurricane Carol." Iosses in the city amounted to more than $\$ 41,000,000$. The tide in the upper bay along the Providence River rose to 14.7 feet above mean sea level, and the resulting flood covered much of the tightly packed commercial area of Providence. The heart of the business section of the city was inundated with 4 to 8 feet of salt water polluted by industrial wastes and sewage. The water level was recorded at $5 \frac{1}{2}$ feet above street level on the front of the Sheraton-Biltmore Hotel in the center of the city. Hundreds of commercial establishments of all types suffered heavy losses, including in many instances a total loss of stock and equipment. Thousands of parked automobiles were inundated and pover, communication, and transportation facilities were totally disrupted. Damages to more than 650 commercial establishments in the city accounted for a total loss of over $\$ 29,000,000$. Providence industries were also hard hit. One of the heaviest individual losses in the city was sustained at the plants of the U.S. Rubber Company on Eagle Street when several of the buildings were inundated with up to 7 feet of water. Other hard hit plants were the Davol Rubber Company on Point and Eddy Streets; the Browne and Sharpe Company, manufacturers of machine tools, machines and metal products, on Promenade Street; the Queen Print Works on Atwells Avenue; and the Narragansett Electric Company. A total of 25 industrial concerns in the city sustained losses amounting to over $\$ 6,700,000$. Danages experienced by utilities, highways, and railroad lines accounted for some 10 percent of the total loss in the city. Table D-3 presents a summary of losses by town and type.

c. West Side: Narragansett Bay. Along the western shoreline of Narragansett Bay south of Providence, from Cranston to Point Judith (Areas II and III), tidal-flood damages amounted to $\$ 28,000,000$. Damages sustained by about 1,700 summer and year-round residences and over 140 commercial establishments along the west shore accounted for over 90 percent of the loss. A total of 230 homes and cottages, the majority in Warwick, were destroyed on this side of the bay, and 13 commercial establishments suffered a total loss of stock, equipment, and in some cases entire buildings. Damages sustained by 15 industrial concerns accounted for a loss of over $\$ 1,900,000$. 
TABLE D-I

DESCRIPTION OF DAMAGE AREAS

NARRAGANSE TT BAY

Area

I

II

III

IV

V

VI

Description

PROVIDENCE RIVER

Provi dence, Rhode Island

WEST SIDE OF NARRAGANSETT BAY

Cranston, Rhode Island

harwick

East Greenwich

North Kingstown

Narraganse tt

Jamestown (Conanicut Island)

EAST SIDE OF NARRACANSETT BAY

East Providence, Rhode Island

Barrington

*tiarren

* Pris tol

Aquidneck Island (west shore)

* Portsmouth and Prudence Island

*Middle town

*Newport

MOUNT HOPE BAY

Swansea; Massachuse tts

Somerset

Dighton

Berkley

Freetown

Fal1 River

* Warren, Rhode Island

*Bristol

*Portsmouth (north shore)

*Tiverton (north of Stone Bridge)

SAKONNET RIVER AND ATHANTIC OCEAN

Aquidneck Island (east shore)

*Portsmouth

* Middle town

*Newport

*Tiverton

(south of Stone Bridge)

Little Compton

* Community in more than one damage area

$\mathrm{D}-4$ 


$$
\begin{aligned}
& \text { 盟 }
\end{aligned}
$$

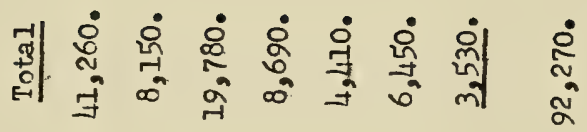

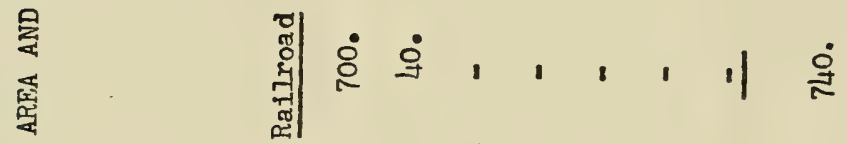

$$
\begin{aligned}
& \text { 崮 }
\end{aligned}
$$

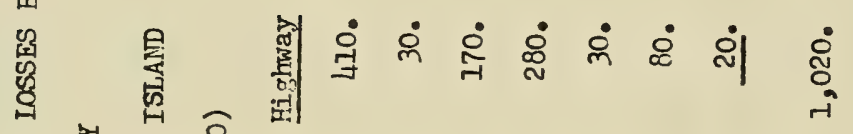

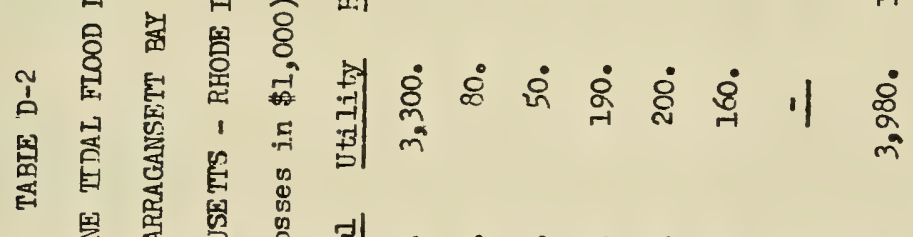

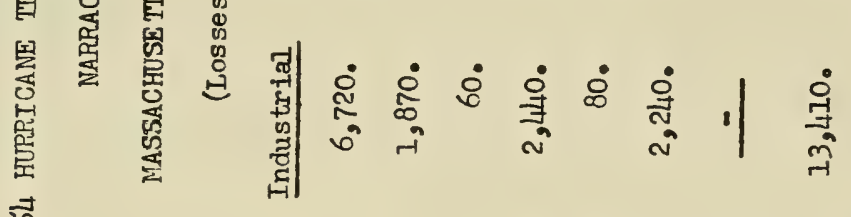

$$
\begin{aligned}
& \text { ฟึ } \\
& \text { 鮮 }
\end{aligned}
$$

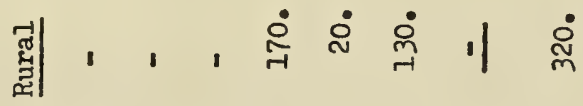

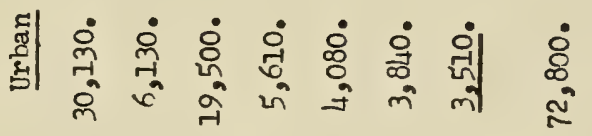

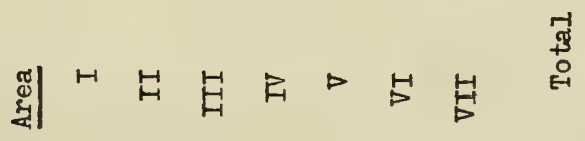




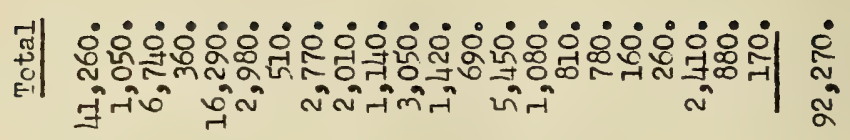

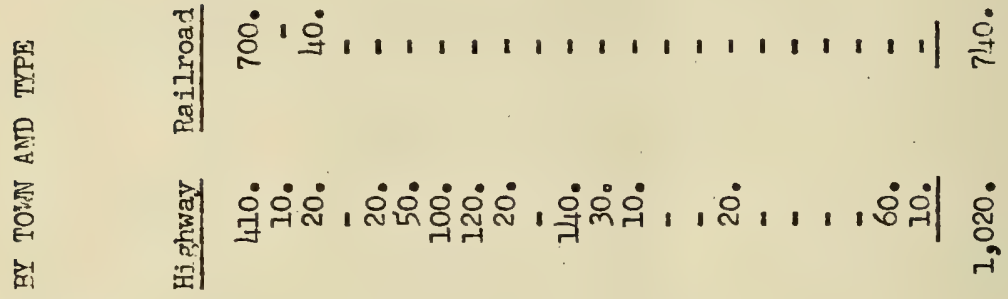

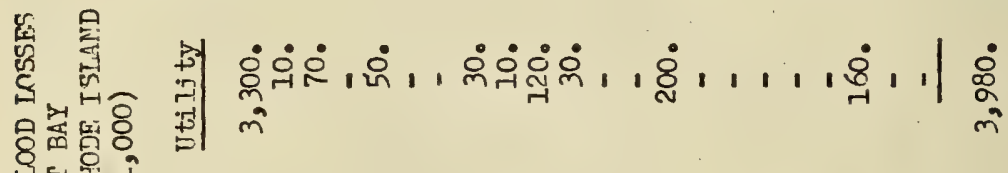

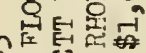

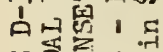

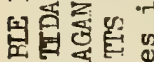

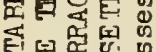

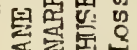

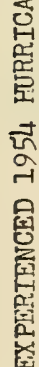

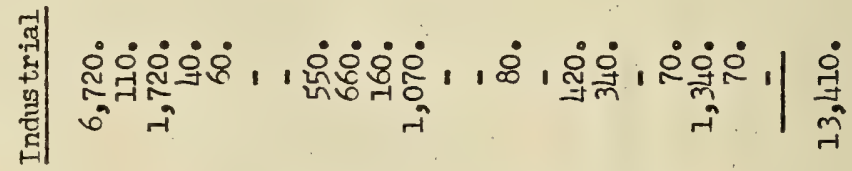

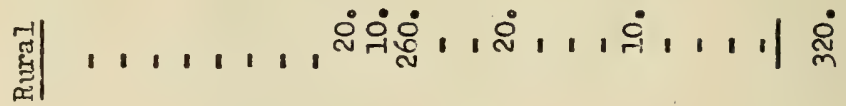

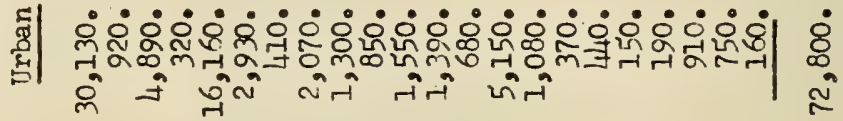
둥

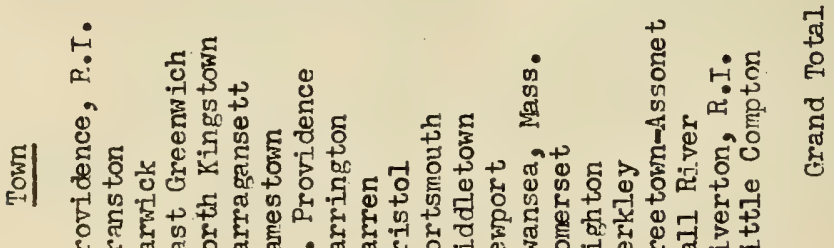

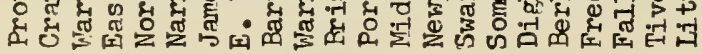


Two of the hardest hit areas on the west side of the bay were the towns of Warwick and North Kingstown. Some of the heaviest destruction in the upper portion of Narragansett Bay took place in the Oakland Beach and Conimicut Point sections of Warwick, where many sumer and year round homes were leveled. The incidence of total destruction was exceptionally high in this area. A heavy toll of property was taken all along the shore from Pawtuxet Cove, where a fleet of more than 100 pleasure boats was wrecked, to Apponaug and Chipiwanoxet at the head of Greenwich Bay and around the southern shore into the Bayridge section of Potowomut. Point House at Conimicut Point and the Shore Dinner Hall at Rocky Point were completely testroyed. The 1954 storm left nothing but the foundation piles of the Rhode Island Yacht Club at Pawtuxet Neck, which had been rebuilt after the same fate in 1938. In the town of Varwick alone almost 900 homes were damaged and over 200 of this number were completely destroyed.

All but 10 percent of the industrial loss of $\$ 1,900,000$ was sustained by four industrial concerns in Warwick. One of the heaviest individual losses in the area occurred at the plant of the Apponaug Textile Finishing Company on Centerville Road. Flooded with 5 feet of salt water, a great amount of equipment was damaged, and thousands of yards of cloth were either damaged or destroyed.

In North Kingstown the destruction was even greater. Major losses included heavy damage to facilities at the Quonset Naval Air Station, the Naval Construction Battalion Center at Davisville, and extensive damage to over 400 homes and 45 commercial establishments in the area. Damages north of the Naval Base were concentrated along the waterfront of the Mount $\nabla$ iew section where residential properties were hard hit, including the loss of considerable land along the waterfront, walkways, and destruction of seawall protection due to wave undercutting.

The exposed shorelines of Narragansett and Jamestown, on Conanicut Island, were also heavily battered by the wind-driven tidal flooding. Over 360 homes in the Narragansett-Jamestown area were damaged, and about 15 were completely destroyed. The large, twostory frame building of the Canonchet Club on the Narragansett waterfront was split in two, and the destruction along the wellknown Narragansett Pier was heavy. The main bathhouse suffered heavy damage, and many rows of bathhouses were washed away. The Jamestown Harbor area was also hard hit. The East Shore Ferry Station was badly damaged, and many cottages were destroyed on East Shore Drive.

d. East Side: Narragansett Bay and Mount Hope Bay. Tidal flood losses on the east side of Narragansett Bay were almost as 
high as those experienced on the west. In the area extending from East Providence to Sakonnet Point (Areas IV, V, VII), including the communities of Rhode Island and southern Massachusetts in the Mount Hope Bay area (Area VI), flood damages amounted to a total loss of over $\$ 23,000,000$. On this side of the bay over 2,200 homes were damaged by tidal flooding, and of that number 195 were either totally destroyed or wrecked beyond repair. of the 265 commercial establishments damaged along the coast, 26 had not resumed operation at the time of the survey in 1955. The combined residential and commercial losses amounted to over $\$ 17,000,000$. Industrial damage along the coast was also heavy. A total of 20 concerns sustained damages amounting to a loss of $\$ 4,760,000$.

Similar to the situation on the west side of the bay, the heaviest losses occurred in areas located in the upper portion of the bay, from Bristol northward. Severe damage was inflicted on coastal property in East Providence, Barrington, Warren, and Bristol (Area IV), representing about 40 percent of the loss on the east side. The East Providence shore suffered heavy damages. Two boat yards and a yacht club were demolished and heavy damage was caused at two oil refineries. The Cook Yarn Company and the Washburn hire Company, flooded with 7 to 8 feet of water, experienced heavy losses.

Warren and Bristol, exposed to tidal flooding from both Narragansett and Mount Hope Bays, were particularly hard hit. The water supplies of both comrnunities were interrupted for a considerable period of time after sea water poured over the Child Street Dike in harren and contaminated the Kickemuit Reservoir. Destruction was intense throughout the Bristol Harbor area. A considerable amount of damage was caused in the harbor by heavy debris which battered shore installations. Damage was especially heavy at the Bristol Boat Yard in the northeast corner of the harbor. A low marsh area near the mouth of Silver Creek at the upper end of the harbor was extensively flooded and remained under water for a considerable length of time due to clogged culverts. The Collins and Aikens Corporation, manufacturers of yarn and cloth, with factories involved in severe tidal flooding in both Barrington and Bristol, sustained one of the highest individual industrial losses in the upper bay area.

Losses in the Mount Hope Bay towns of southern Massachusetts amounted to $\$ 5,500,000$ (part of Area VI). Overflow of the tidal reach of the Taunton River extended inland as far as the town of Dighton, causing damages to waterfront installations and residential property in Somerset, Berkley, Freetown, and Assonet. The Brayton Point area in Somerset was hard hit and the Somerset Yacht Club was completely destroyed. Swansea and Fall River 
were, however, the two major damage centers in this area of Massachusetts. In Swansea, flooded by both the bay and overflow of the tidal reach of the Lees River, the incidence of the total destruction of homes and cottages was high. A total of 45 of the 200 homes affected were completely destroyed.

The city of Fall River, where heavy damage was sustained by four industrial concerns, suffered the heaviest losses of any community in the bay area of Massachusetts. Damages at the plants of the Firestone Company along Ferry Street, one of the hardest hit concerns in the area, included extensive destruction of equipment, raw materials, and finished goods.

Losses on the eastern shore of Narragansett Bay below Bristol amounted to over 35 percent of the total loss sustained on the east side. The shore line of Aquidneck Island was heavily battered on the south and west by the hurricane tide of Narragansett Bay and by the Sakonnet River on the East. Losses in Portsmouth, Middletown, and Newport were heavy. One of the hardest hit sections in the northern end of the island was Island Park in Portsmouth.

At the southern end of the Island, the city of Newport, with a long, exposed shoreline, was by far the hardest hit community in this area. The entire south shore of the city was heavily battered by the hurricane tide. Residential and commercial damage was intense. In the vicinity of Long Wharf, the water rolled inland as much as 2,000 feet beyond the face of the piers, flooding hundreds of houses and stores as well as numerous warehouses and storage buildings. Recreational and commercial boats were smashed or carried onto the docks and, in some cases, driven into buildings. Along the shoreline below the city, beaches and cottages sustained severe damage. Cottages and bathhouses at Hazard and Bailey Beaches were either completely destroyed or driven far inland to the northern shore of Lily and Almy Ponds. At Easton's Beach everything was carried away except the main administration building and some sections of the bathhouse. Along the eastern side of Newport Neck, huge chunks of cliff and shore were ripped away. Widespread devastation was caused by the Sakonnet River in the low areas of Island Park, where scores of cottages were leveled along the shore and through the center of the area. Heavy damage to Stone Bridge, which crosses to Tiverton, cut off the only route to higher land during the storm. Across the Sakonnet River in the Tiverton-Little Compton area, damage was severe in some sections. Property along Riverside Drive in Tiverton was heavily damaged, and the Nanaquacket Bridge was swept away.

In addition to the extensive residential, commercial, and industrial losses in the Narragansett Bay area, damages sustained by 
craft afloat and automobiles in the flood area accounted for considerable losses which were not included or included only in part, because loss information in usable form was meagre or unavailable. Available evidence indicates, however, that these losses were substantial in the 1954 and 1938 tidal flooding. Other unevaluated losses include intangible damages such as loss of life, health, security and menace to national defense.

\section{D-3. RECURRING DAMAGES}

a. General. Stage-loss curves, described in subsequent paragraphs, indicate that a recurrence of the record flood of september 1938, under present economic conditions, would cause losses estimated at $\$ 120,200,000$ in the areas to be protected by the plan. (All recurring losses are estimated at 1956 price levels.) Tidal stages produced by a storm of the 1954 magnitude would result in losses of $\$ 92,200,000$. The design flood, which would cause flood levels from 2 to 3 feet in excess of 1938 stages, would cause an estimated total loss of approximately $\$ 204,000,000$. Refer to Table $D=5$ on page $D-15$ for a tabulation of recurring losses of damaging hurricanes and storms which have occurred within the last 50 years.

As the basis of the economic analysis, stage-loss curves referenced to the 1954 flood level have been developed. These stage-loss curves, based on data obtained by damage surveys made subsequent to the 1954 hurricane flood, provide a method by which the magnitude of recurring losses at stages up to 3 feet above the experienced 1954 stage may be determined. The difference between the losses experienced in the flood of 1954 and the recurring losses used to develop the new stage ${ }^{\prime}$ loss relationship reflects the economic and physical changes in the area since 1954 which were revealed by the damage surveys initiated one year after the hurricane flood.

An additional analysis would be required in the final design of the Lower Bay barriers to more accurately determine the effects of wave action in the lower stages of the stage-damage curves for controlling areas.

A number of primary flood losses, both tangible and intangible, have not been included in the economic analysis of protective measures, even though these losses may be substantial in a given instance of tidal flooding. Tangible losses in this category are made up of ( 1 ) damages to vehicles either underway or parked on street or in public or commercial parking lots; (2) damages to small craft and vessels afloat at shore facilities, or in open 
water within the protection area which are subject to an indeterminate combination of wind, waves, and tide; and (3) losses to shellfish beds which are disturbed or contaminated. Losses such as these have been omitted from the economic analysis, because they consist of damages to items which are not always present in the same place, at the same time, or in the same quantity. To put losses in this category in perspective for analysis would require a framework of multiple assumptions.

The following paragraphs describe the economic and physical changes, in addition to price level changes, which are reflected in the computation of recurring flood losses.

b. Evaluation of individual flood-protection measures. The stage-loss relationship reflects an evaluation of the effectiveness of permanent and semi-permanent flood protection devices and measures where they have been installed since the hurricane of 1954 at industrial concerns, commercial houses, and public buildings. These protective measures include permanent closure of windows and other openings, provision for closure of discharge lines, extension and reinforcement of walls, construction of flood walls, installation of pumps to control seepage and interior runoff, evacuation of plant storage space susceptible to flooding, and the organization of flood plans to put semi-permanent closures and evacuation of vulnerable soace into effect. Credit for these types of individual protection measures has been assumed to influence the stage-loss relationship to a stage one foot below that of 1954.

Credit for local protection measures to the full 1954 stage was not considered reasonable because of the weaknesses inherent in this kind of protection and the many unknowns involved in local floodprotection problems. These unpredictable factors include (1) the vulnerability of both walls and floors to the hydrostatic pressure created by flooding of the 1954 magnitude; (2) the possibility of overtopping by hurricane flood peaks; and (3) the danger of a breakthrough under the battering of wind-driven debris, which would permit salt water to enter and thereby nullify all other protective measures.

In addition to the possibilities of physical failure, the effectiveness of plant protection is further weakened by the critical importance of the time element involved in putting flood plans into operation. Owing to the heavy non-recoverable losses incurred by a complete plant shutdown, concerns are reluctant to put their plans into total operation until dangerous flooding is iminent. Considering the vagaries of hurricane novements and warning systems, this delay can be disastrous. Optimum conditions, including a sufficiently early hurricane flood warning at a time when adequate numbers of per- 
sonnel are available to put a plan into successful operation, must exist before the protective devices which have been installed can be fully utilized.

c. Normal recovery. Recurring losses also reflect changes in the affected areas resulting from the complete destruction of property in the flood of 1954. Where property was destroyed in 1954, an allowance has been made for normal recovery. Based on evidence of recovery noted in the damage surveys and on the rate of reconstruction in the area in the years following the hurricane of 1938 , a 30 percent recovery of loss potential, with additional allowance for increased costs, has been incorporated in the computation of recurring losses.

d. Normal growth. The future growth in the flood areas of Narragansett Bay was estimated on the basis of population growth between 1930 and 1950, and population projections to 1970 . A 20year projection was adopted in order to reflect economic conditions near the mid-point of the project life. It was assumed that urban growth (residential, commercial, public), which was taken as an index of the rate of prowth in the affected areas of the bay, would proceed at only one-half the rate of growth outside the flood areas, on the basis that (I) the shore areas of Narragansett Bay are already hichly developed, and that (2) less urban growth could be expected in areas threatened by tidal flooding.

Population movements and a heavy concentration of urban development in the flood area indicated there would occur little or no growth in the flood area of the city of Providence. Annual losses and benefits in the protected areas below Fox Point barrier were increased by six percent in order to reflect an increased loss potential due to increased growth.

\section{D-4. ANNUAL LOSSES AND BENEFI IS}

a. General. The benefits of the plan to control tidal flooding in the Narragansett Bay area consist of flood damage prevention benefits and benefits from the elimination of scare costs.

The flood damage prevention benefits are by far the most important. Inasmuch as derivation of annual losses and benefits for hurricane flooding and flood protection measures is a new venture, annual benefits have been derived by two methods. The basic method utilizes the standard practice of the Corps of Engineers of correlation of stage-damage and stage-frequency to develop a damage-frequency curve. Benefits derived by this method 
are made un of the difference between annual losses under preproject and nost-project construction conditions. An alternative method used for comperative rumposes was an evaluation of savings by the recommended protective works in a recurrence of hurricanes and storms that have occurred in the pest 50 years. The 50-year period was selected to conform with the economic life of the project used for cost amortization. The alternative method resulted in benefits of a comparable magnitucie to those derived by the damage-frequency method. The benefits derived by the damage-frequency method were used in detemining berefit-cost ratios.

\section{b. Average annual losses. The Narragansett Bay area was} divided into 8 damage areas and 13 sub-areas for the rurpose of econonic analysis. A descriction of these areas is shom on Table D-4.

Recurring stage-damace data for individual properties, referenced to the peak elevation of the 1954 burricane rlood, was summarized ior each of the damage areas which are rithin the plenned protection. The stage-damare curve was combined with stage-frequency date to develop a damare-frequency curve. The development of the stage-frequency curve is described in Appendix B. The damage-rrequency curve was plotted with damage as the ordinate and percent-chance-of-occurrence (reciprocal of frequency) as the abscissa. The area under the demage-frequency curve is a measure of the average annual loss. By this method, the average annual losses in the areas of Narragansett Bay which would be Frotected by the plan amounts to $\$ 5,922,000$, at 1956 price levels, of which $1,697,000$ occurs in the area above the Fox Point barrier, and 4,225,000 between Fox Foint barrier and the Lower Bay barriers.

A recurrence of the 3 major hurricanes and 22 other storms causing tidal flooding which occurred in the past 50 years would occasion losses evaluated at $\$ 227,200,000$, or $\$ 4,544,000$ annually, under present economic conditions. Table D-5 shows a tabulation of losses which would result in the areas to be protected by the plan under present economic conditions in the event of a recurrence of the tidal-flood stages produced by destructive hurricanes and storms which have occurred within the last 50 years. The curves on Flate D-1 are representative of the stage-damage and damage-frequency relationships found in the Narragansett Bay areas.

c. Average annual flood-prevention benefits. Average annual flood-prevention benefits were derived by determining the difference between annual losses under present conditions and those remainine after construction of the projects in the plan. A stagefrequency curve reflecting post-project conditions was used to develop post-project annual losses. Annual benefits in the protected areas of the Narragansett Bay area amount to $5,902,000$, of which $\$ 1,697,000$ would accrue to the area above the Fox Point barrier and 


\section{DESCRIPTION OF DAMAGE AREAS}

USED FOR ECONOMTC ANALYSES

Description

1 Providence, East Providence, Cranston

la: Providence above South Street

Ib Providence Irom Fox Point to South Street

Ic Providence and East. Providence from Fields Point to Fox Point

Id East Providence and Cranston below Fields Point

2 harwick

2a Above Conimicut Point

2b T'arwick Neck

3 East Greenwich, Warwick: Excluding Area 2 in Warwick

4 Barrington, Warren, Bristol

4a Barrington above Nayatt Point

$4 \mathrm{~b}$ Barrington, Warren, and Bristol from Nayatt Point in Barrington to Mount Hope Bridge in Bristol including Mount Hope Bay area to MassachusettsThode Island Iine

5 Swansea, Somerset, Dighton, Berkley, Freetown, Fall Fiver Mount Hope Bay and Taunton River areas in Massachusetts

6 Prudence Island, Portsmouth, Tiverton Iorth Pmidence Island north of Homestead, Island Park Area of Portsmouth, and Tiverton north of Stone Bridge

7 Portsmouth, Prudence Island, North Kingstown Portsmouth excluding Island.Park area, Prudence Island south of Homestead, North Kingstorn from Quonset Point to North Kingstown-East Greenwich town Iine

8 North Kingstown, Jamestown, Middle town, Newport North Kingstown from wonset Point to Lower Bay Barrier, Jamestown north of Lower Bay Barriers, Middletown and Newport north of Lower Bay Barrier 


\section{TABLE D-5}

RECURRTNG TIDAL FLOOD IOSSES

MAJOR HURRICANES AND OTHER STORMS

DURING PAST 50 YEARS

NARRAGANSETT BAY PROTECTION AREA

(Losses in $\$ 1,000$ at 1956 Price Levels)

\begin{tabular}{|c|c|c|c|c|c|}
\hline Area & $\begin{array}{l}\text { Minor } \\
\text { Floods } \\
\end{array}$ & $\begin{array}{l}1938 \\
\text { Flood } \\
\end{array}$ & $\begin{array}{l}1944 \\
\text { Flood }\end{array}$ & $\begin{array}{l}1954 \\
\text { Flood } \\
\end{array}$ & Total \\
\hline Ia & 100. & 37,810 。 & 740. & 28,610 . & 67,260 \\
\hline Ib & 70. & 3,810 . & 160 . & 2,970 . & 7,010 . \\
\hline lc & 160. & 18,290 。 & 700 . & 14,340 . & 33,490 . \\
\hline ld & 130. & 2,010 . & 150. & 1,630 . & 3,920 。 \\
\hline $2 a$ & 140. & 300 . & 40. & 240. & 720 . \\
\hline $2 b$ & 700. & $2,930^{\circ}$ & 300 . & 2,300 . & 6,230 . \\
\hline 3 & 350. & 4,780 . & 380. & 3,710 . & 9,220 . \\
\hline $4 a$ & - & 1,540 。 & - & 1,080 . & 2,620 . \\
\hline $4 b$ & 620. & 7,150 & 350. & 5,170 . & 13,290 。 \\
\hline 5 & 540. & 7,830 。 & 370. & 5,390 . & 14,130 . \\
\hline 6 & 330. & 2,500 . & 170 . & 1,660 . & 4,660 . \\
\hline 7 & 2,470 . & 20,240 & 2,480 。 & 16,650 . & $47,840$. \\
\hline 8 & $2,280$. & 11,030 . & 1,020 。 & $8,480$. & 22,810 \\
\hline Totals & 7,890 。 & 120,220 & 6,860 。 & 92,230 . & 227,200 \\
\hline
\end{tabular}


$\$ 4,205,000$ to the area between Fox Point barrier and the Lower Bay barriers. The damages preventable by the recommended plan in a recurrence of the storms of the past 50 years amount to $\$ 226,880,000$, or $\$ 4,538,000$ annually.

d. Scare-cost benefits. In addition to flood-prevention benefits, significant losses are sustained in areas susceptible to tidal flooding due to the institution of temporary preventive measures as the result of hurricane warnings, whether the areas are flooded or not. Based on data gathered in the course of damage surveys conducted subsequent to the flood of August 1954 in the Narragansett Bay area, it is estimated that in the areas susceptible to tidal flooding 25 percent of the commercial establishments and 50 percent of the industrial concerns attempt to minimize their potential losses through temporary preventive measures. The estimated benefits to the Narragansett Bay projects, by eliminating the scare costs of a single hurricane warning, amount to $\$ 325,000$. Based on a frequency of 3 hurricane warnings in a 10-year period, the average annual benefits amount to $\$ 98,000$, with $\$ 36,000$ accruing to the area above the Fox Point barrier and $\$ 62,000$ between Fox Point and the Lower Bay barriers.

e. Increased utilization benefits. A field investigation was made of the flooded areas for the purpose of determining the extent of benefits attributable to changes in land use and development that could be credited to the project. The area of the City of Providence protected by the Fox Point barrier is already built up and benefits of this nature would be relatively small. Below the Fox Point barrier the investigation revealed that about one-fourth of the shore is in public ownership, mainly the Department of the Navy. Land for development is distributed at intervals along the shores of Rhode Island and Massachusetts. In view of the demand for shoreline property for the National Defense, commercial and residential use, the development of these areas is likely to occur without flood protection so that increased utilization benefits are speculative in nature, and it is not practicable to estimate these benefits. The total possible utilization benefits would comprise only a minor portion of the total benefits creditable to the Lower Bay barriers.

SUMMARY OF BENEFITS

Fox Point

Barrier

Flood-Damage Prevention

Scare-Costs Prevention

Total $\begin{array}{r}\$ 1,697,000 \\ 36,000 \\ \hline\end{array}$

$\$ 1,733,000$
Lower Bay

Barriers

$\$ 4,205,000$

62,000

$\$ 4,267,000$
Total

$\$ 5,902,000$

$\underline{98,000}$

$\$ 6,000,000$ 

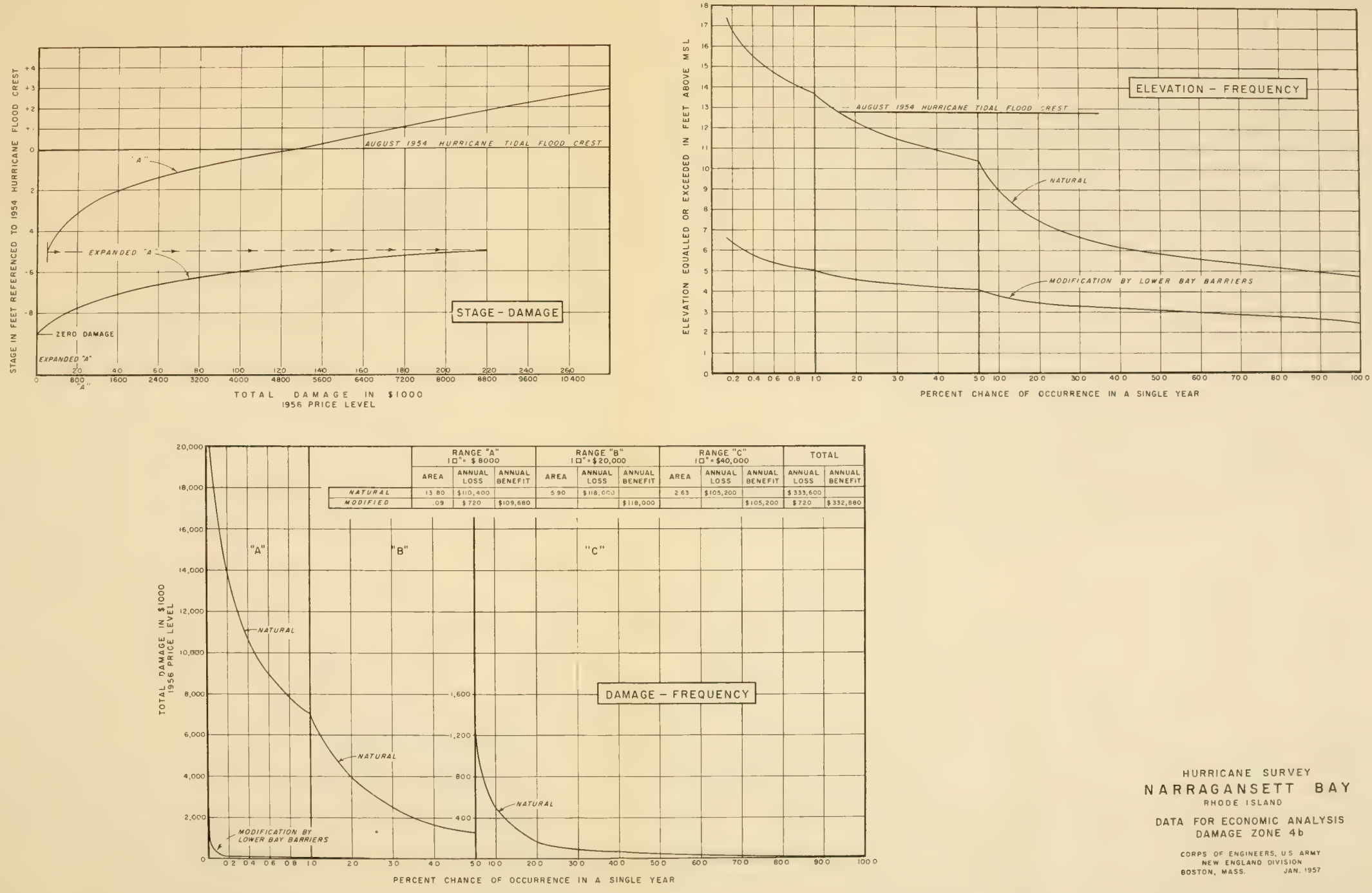

HURRICANE SURVEY

NARRAGANSETT BAY

DATA FOR ECONOMIC ANALYSIS

DAMAGE ZONE 40

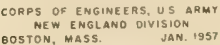



APPENDIX E

GEOLOGY AND FOUNDATION DATA 

APPENDIX F

DESIGN STUDIES AND COST ESTIMATES 



\section{APPEIDIX F \\ DESIGN STUDIES AND COST ESTTAATES}

\section{INTRODUCTION}

F-1. The design features and cost estimates for the recommended plan of hurricane protection for Narragansett Bay, consisting of the Fox Point barrier and three Lower Bay barriers, are presented in this appendix. The locations of these projects and of the other sites considered are shown on Plate F-1. The principal features of the recommended plan are shown on Plates 3 to 7 inclusive, in the main report.

\section{SURVEYS AND EXFLORATIONS}

F-2. Both the designs and cost estimates for the selected plan are based on recent topographic and hydrographic surveys and subsurface investigations. Special topographic maps, scale 1:2400, with 2-foot contours, were prepared by the Coast and Geodetic Survey for the Fox Point area and for the center of Providence. The standard quadrangle sheets of the U.S. Geological Survey were used for the Lower Bay East and west barriers. In addition, photogrammetric maps of the Fublic Works Department of the State of Rhode Island were available for the Tiverton barrier site, and supplementary information was obtained by fleld surveys.

Fathometer surveys were made of the selected sites where necessary.

Subsurface investigations, described in Appendix E, included a total of 29 borings. Borings were available for the West barrier and Tiverton sites, and selsmographic studies were made for the East barrier.

\section{DESIGN CRITERIA}

F-3. The structures have been designed to withstand a design hurricane. Both the design criteria and the selected top elevations are shown in Table F-I, below. Appendix B contains further details on design tidal flood and design waves. 


\section{TABLE P-I}

DESTON CRITERIA AND SELECTED TOP ELEVATIONS

Fox Point $\begin{gathered}\text { Lower Bay } \\ \text { Warrier Barrier Barrier } \\ \text { Bartor }\end{gathered}$

Still-water elevation

(feet m.s.1.)

Maximum wave height

(feet)

Selected top elevation of

barrier (feet m.s.1.)

$\begin{array}{rrrr}18.7 & 13.3 & 14.8 & 17.6 \\ 6.0 & 25.0 & 20.0 & 9.0 \\ 22.5 & 22.0 & 22.0 & 20.0\end{array}$

BASIS OF COST ESTTMATES

F-4. COST ESTTMATES

The costs of the barriers have been estimated on the basis of designs which will provide economical and safe structures. Embankment quantities include allowances for settlement. An allowance for eight feet of settlement was made in the embankment quantities for the West barrier. In the East barrier, for an assumption of favorable foundation conditions, a settlement of 20 feet was used. A settlement of 50 feet was used in the assumption for unfavorable foundation conditions.

F-5. UNIT PRICES

Unit prices are based on the most nearly comparable large marine projects in this section of the country, with adjustments for the size and nature of the project, availability of materials, and adjustment to 1956 price levels. Rock prices for the East and West barriers reflect the costs of equipment, such as bottom-dump barges, written off in the first 6,000,000 cubic yards.

F-6. CONTINGENCIES, ENTGINEERTNG, AND OVERHEAD

The estimates include allowances for contingencies, engineering, design, supervision and administration. These allowances are based upon experience, evaluation of the site and the project, and comparison with other projects of the nearest comparable magnitude and character1stics. 


\section{F-7. ANNUAL CHARGES}

The estimate for annual charges is based on interest on the total investment, amortization, allowance for loss of taxes, operation and maintenance. The Federal and non-Federal investments include the first cost plus 2.5 percent interest during construction. The Federal annual charges include interest on the investment at 2.5 percent and amortization over a period of 50 years. The non-Federal annual charges include interest on investment at 2.5 percent, amcrtization over a period of 50 years, tax losses, maintenance and operation.

\section{FOX POINT BARRIER}

\section{F-8. DESCRIPTION AND PERTINENT DATA}

a. General. The Fox Point barrier would consist of a dam with gated openings and a pumping station. The 1,100-foot barrier would cross the Providence River from Henderson Street on the west bank to Fox Point on the east bank, and would tie into a concrete land-wall system, 3,040 feet in length, connecting the barrier to high ground at each end. For plans and details see Plates 3 and 4 of the report.

b. Barrier. The barrier would be a concrete gravity section 40 feet in width, with a deck elevation 12.5 feet above mean sea level, and a reinforced concrete wall 10 feet in height, extending the full length of the barrier on the upstream side. The gravity section would be founded on a concrete base 50 feet in width supported by steel "H" piles driven to refusal in the glacial till.

c. Sluice gate structure. This structure would be founded on a concrete base supported by steel "H" piles and would contain four openings 20 feet wide by 24 feet high. Closure would be effected by four gates hinged at the top.

d. Cooling water intake structure. This structure would furnish cooling water to the existing generating plants of the Narragansett Electric Company. The cooling water intake would consist of a sated inlet 20 feet wide and 32 feet high and a channel 50 feet wide and 2,700 feet long. An emergency opening adjacent to the barrier consisting of three manually operated gates would permit the entry of cooling water during a hurricane when the sluice gates would be closed. 
e. Pumping station. The pumping station would consist of five rertically mounted axial flow pumps, powered by five 6000 Hr electric motors in a concrete structure. The structure would contain a work bay, office space, and a traveling crane.

f. Land walls. The land walls, extending east and west of the barrier, would be concrete cantilever sections having a top elevation of 22.5 feet above mean sea level. These walls would contain stop log structures at street and railway crossings.

g. Pertinent data. Summarized information relating to the Fox Point barrier is presented in Table F-2.

TABLE F-2

PERTINENT DATA - FOX POINT BARRIER

Barrier

Type

Top elevation, feet m.s.l.

Deck elevation, feet m.s.l.

Length, feet

Madimun height, feet
Concrete gravity

22.5

12.5

1,100

62.5

\section{Sluice gates}

Openings

Gates

Type

Net area

Total design discharge

\section{Cooling Water Intake}

Opening

Gate

Type

Net area

Design intake

\section{Purring Station}

Building

Pumps

Motors

Design capacities
4 - $20 \mathrm{ft}$. by $24 \mathrm{ft}$. 4 - $20 \mathrm{ft}$. by $30 \mathrm{ft}$. Steel drop $480 \mathrm{sq}$. ft each 9,200 c.f.s.

1 - $20 \mathrm{ft}$. by $32 \mathrm{ft}$. 1 - $20 \mathrm{ft}$. by $34 \mathrm{ft}$. Steel drop $640 \mathrm{sq}$. ft. 1,300 c.f.s.

Reinforced concrete 5 - 120 inch 5 - $6000 \mathrm{HP}$ electric $8,000 \mathrm{c.f.s}$. $22 \mathrm{ft}$. head 9,200 c.f.s. $16 \mathrm{ft}$. head 


\section{TABLE F-2 (continued) \\ PEITINENT DATA - FOX POINT BARRIEK}

Land: Walls

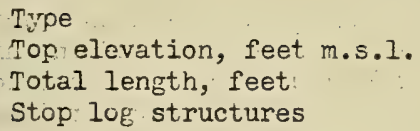

Concrete cantilever wall 22.5

3,040

F-9. DESIGN

2. General. The structure has been designed to withstand a hurricane tidal surge of 18.7 feet above mean sea level with a coincident storm runoff of 9,200 cubic feet per second.

b. Barrier. The shape of the barrier structure was determined by the need for stability to resist the storm surge, for structural continuity between the component parts, and for applicability to possible future wharfage or highway use. The 37-foot wide deck was selected at elevation 12.5 feet above mean sea level, for wharf use or access from either shore.

c. Sluice gate structure. This structure as a part of the main barrier meets the same design criteria. The gate openings are designed to pass the peak flood runoff of 9,200 cukic feet per second at a differential nead of one foot. The capacity is sufficient to insure full tidal flushing above the barrier under the normal conditions.

a. Coolin water intake structure. This structure is designed to allow the passate of $1, \overline{300}$ cubic feet per second of cocling water for the renerating: plants of the Narragansett Electric Company. Exhaust water dischareses by means of concrete pipes across the intake channel into the river. The emergency intake structure is designed to furrish the sume quantity of water into the intake channel when the barrier gate is closed. Present and reasonable future needs of cooling water for the generating stations are met by the design quantity of 1,300 cubic feet per second.

e. Pumping station. This structure is needed to discharge the fresh water inflow during the design storm concurrent with a hurricane surge to prevent upstream flooding. Overtopping at the time of peak inflow would be ponded behind the barrier. The five 120-inch pumps would be capable of discharting 8,000 cubic feet per second against a 22-foot differential head. During hurricane periods, the pool woild be maintained at an elevation of 3 feet below mean sea level for inflows up to 8,000 cubic feet per second. This would facilitate rapid drainage above the barrier. In the event of a maximum storm runoff of 9,200 cubic feet per second, the pumps could pass this larger quantity with ponding to an elevation 3 feet above mean sea level. 
Power for operating the pumps would be provided by the generating stations of the Narragansett Electric Company, to be protected by the barrier. Two stations havin a total generating capacity of 330,000 kilowatts are located within 2,000 feet of the pumping station. Electric power, supplied by direct underground service, would be available from either or both stations. These stations are tied in to the main transmission line of the New England Electric System which withstood the high winds of past hurricanes. Considering the reliability of these services of electric power no provision has been made for standby power or diesel pumps.

f. Foundations. Due to the poor foundation conditions piles were considered essential. Steel "H" piles were selected due to ease of handling, splicing and driving. Steel sheet piling was provided as forms for the tremie concrete cofferdam and as a seepage cutoff.

g. Land walls. The land walls were designed for a water loading to the top of the wall on the seaward side.

F-10. MODIFICATIONS TO SEWERS AND DRAINAGE

Gates would be provided on sewers and drains which pass under the land walls. During a hurricane the gates would be closed and the flow diverted.

\section{F-11. LANDS AND DAMAGES}

No major street or highway relocations would be caused by the construction of the Fox Point barrier. The structures, where they do not adjoin streets, would require strips of land for construction and maintenance. Where they do adjoin streets, some highway modifications would be required, but they would not obstruct traffic.

The existing waterway above the barrier presently services the Narragansett Electric Company, the Block Island Ferry and others. The use of the waterway must be discontinued and other facilities substituted.

\section{F-12. PLAN OF CONSTRUCIION}

During the first construction season the foundation of the cooling water intake structure would be installed and the pumping station cofferdam would be placed. Piles would be driven for the pumping station, the foundation mat poured, and the substructure, including pump housings, draft tubes, and trash racks, would then be constructed. The cofferdam would be removed, and foundation and substructure for the sluice gates and barrier proper would be completed. 
During the second construction season, the gravity dam section and the sluice gate super-structure, cooling water intake, and pumping station would be completed. Land walls and stop log structures would be constructed. It is estimated that all work could be completed in two seasons.

\section{F-13. OPERATION AND MAINTENANCE}

During a hurricane alert, the sluice gates would be closed by tripping the drop mechanisms. The cooling water intake through the bamrier would be closed when the situation became acute. The emergency intake gates inside the barrier would be opened, and maintenance personnel would stand by for pumping to maintain the fresh-water pool at or below mean sea level.

Operation of the Fox Point barrier at other times would consist solely of maintenance procedures. The sluice gates would remain open to permit river flow and tidal interchange, and the cooling water intake gate would be open to permit the entrance of water from the bay.

Maintenance of the barrier and pumping station would require a regularly assigned maintenance crew. Periodic testing of machinery would be carried out about once a month along with lubrication, painting, and other procedures as required.

F-14. COST ESTIMATES

A detailed estimate of the first cost for the Fox Point barrier is given in Table F-3. The estimated annual charges of $\$ 584,000$ are shown in Table F-4.

\section{F-15. ALTERNATIVE PLANS FOR FOX POINT}

a. General. Studies of alternative barrier alignments, and of different types of structures, were made at several locations in the Fox Point area. The major alignment studies were (I) an alignment from Fox Point, crossing the Providence River normal to the center line of the river, and (2) alignments from Fox Point to the vicinity of Henderson Street. The structures investigated were rock and earth filled sections used in conjunction with concrete appurtenant works, and structures constructed completely of concrete. 
TABLE F-3

ESTIMATED FIRST COSTS

FOX POINT BARRIER

(1956 Price Level)

\section{Item}

Dredging

Pile Foundation

Sheet Plling

Sand F1II

Concrete - Tremie

Concrete - Mass

Concrete - Structural

Riprap

Dewatering Dam and

Gate Structure

Sub-Total

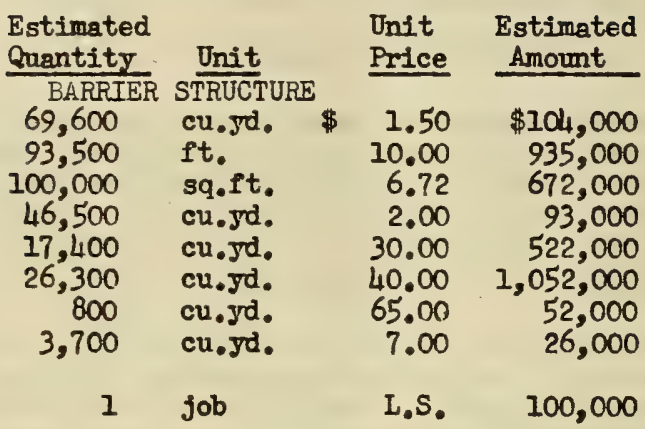

SLUICE GATE STRUCTURE

Dredging

Pile Foundation

Sheet Piling

Sand Fill

Concrete - Tremie

Concrete - Structural

Gates and Hoists

Riprap

$\begin{array}{rlrr}9,250 & \text { cu.Jd. } & 1.50 & 11,000 \\ 11,600 & \text { ft. } & 10.00 & 116,000 \\ 15,600 & \text { sq.ft. } & 6.72 & 105,000 \\ 5,000 & \text { cu.Jd. } & 2.00 & 10,000 \\ 3,600 & \text { cu. Jd. } & 30.00 & 108,000 \\ 1,280 & \text { cu.Jd. } & 65.00 & 83,000 \\ 4 & \text { each } & 15,000.00 & 60,000 \\ 288 & \text { cu.Jd. } & 7.00 & 2,000\end{array}$

Sub-Total
$\$ 3,556,000$

\section{Totel}

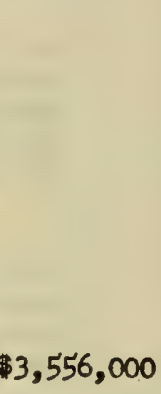

$\$ 498,000$

$\begin{array}{lrlrr}\text { Dredging } & 4,670 & \text { cu.Jd. } & 1.50 & 7,000 \\ \text { Pile Foundation } & 2,600 & \text { ft. } & 10.00 & 26,000 \\ \text { Sheet P1ling } & 10,000 & \text { sq.ft. } & 6.72 & 67,000 \\ \text { Sand F1ll } & 2,000 & \text { cu.Jd. } & 2.00 & 4,000 \\ \text { Concrete - Tremie } & 1,200 & \text { cu.jd. } & 30.00 & 36,000 \\ \text { Concrete - Structural } & 600 & \text { cu.Jd. } & 65.00 & 39,000 \\ \text { Gate and Hoist } & 1 & \text { job } & 1.5 . & 15,000 \\ \text { Riprap } & 144 & \text { cu. yd. } & 7.00 & 1,000 \\ \text { Energency Intake } & 1 & \text { job } & \text { L.S. } & 10,000 \\ \text { Exhaust Outlets } & 1 & \text { job } & \text { L.S. } & 40,000 \\ \text { Sheet P1ling, Channel } & 145,000 & \text { sq.ft. } & 4.48 & 650,000\end{array}$

COOLITG WATER STRUCTURE 


\section{TABLE F-3 (Continued)}

Item

\section{Cofferdam}

Dredging

Pile Foundation

Draft Tube Forms

Concrete - Structural

Structural Steel, Utilities and

Hiscellaneous Items

Taintor Gates and Equípment

Pumps and Motors

Stop Logs, Trash Racks and Equipment

Sheet riling

Back Fill

\section{Estimated}

Quantity Unit

PUMPING STATION

$$
\begin{array}{rlr}
1 & \text { job } & \text { L.S. } \\
36,600 & \text { cu,yd. } & 1.50 \\
42,000 & \text { ft. } & 10.00 \\
5 & \text { each } & 3,600.00 \\
17,250 & \text { cu.yd. } & 65,00
\end{array}
$$

Unit Estimated Amount

Totel

Sab-Total

1 job

I,S

500,000

1 job

1 job

L.S.

L.S.

200,000

$2,211,000$

$\begin{array}{rlr}1 & \text { job } & \text { L.S. } \\ 12,700 & \text { sq.ft. } & 4.48 \\ 5,000 & \text { cu.jd. } & 3.00\end{array}$

300,000

57,000

15,000

$\$ 5,397,000$

APPROACH STRUCTURE AND RAMPS

$\begin{array}{lrlrr}\text { Pile Foundation } & 13,700 & \text { ft. } & 10,00 & 137,000 \\ \text { Concrete - Structural } & 4,000 & \text { cu.yd. } & 65.00 & 260,000 \\ \text { Fill } & 23,900 & \text { cu.yd. } & 3.00 & 72,000 \\ \text { Paving } & 11,000 & \text { sq.yd. } & 3.00 & 33,000 \\ \text { Stop Log Shed } & 1 & \text { job } & \text { L.S. } & 10,000 \\ \text { Sheet Piling } & 15,000 & \text { sq.ft. } & 4.48 & 68,000\end{array}$

Sub-Total

$\$ 580,000$

LAND WALIS AND STOP LOG STRUCTURES

Concrete-Structural

Stop Log Structures $\begin{array}{rr}4,700 & \text { ex.yd. } 65.00 \\ 4 & \text { each } 8,500.00\end{array}$
306,000

34,000

Sub-Total

$\$ 340,000$ 


\section{TABLE F-3 (Continued)}

Unit Estimated

Price Amount Total

Sub-Total, Construction Cost $\$ 11,266,000$

Contingeneies

Engineering and Design

Supervision and Administration

*Electric Power Installation

$$
\text { Sub-Total }
$$

FEDERAL FIRST COST

Lands and Damages

Sewer and Drainage Modifications

NON-FEDERAL FIRST COST

TOTAL FIRST COST
L.S. $\$ 1,693,000$

L.S. $1,246,000$

L.S. $1,140,000$

L.S. 835,000

$$
4,914,000
$$

$16,180,000$

200,000

120,000

*Note: The item of Electric Power Installation above represents a separate estimate of the cost of power supply, including allowances for engineering and contingency. 
TABLE F-4

ESTIMATED ANNUAL CHARGES

FOX POINT BARRIER

(1956 Price Level)

Federal Investment

Total Federal First Cost Interest during Construction Total Federal Investment $\$ 16,180,000$ 404,000 $\$ 16,584,000$

Federal Annual Charges

Interest on Federal Investment (2.5\%)

Amortization ( 50 years)

414,, 00

Total Federal Annual Charges

170,000

Hon-Federal Investment

Total Non-Federal First Cost

Interest during Construction

Total Non-Federal Investment

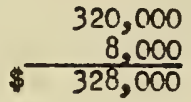

Non-Federal Annual Charges

Interest on Non-Federal Investment

Amortization (50 years)

Estimated Tax Losses

Maintenance and Operation

Salaries, Overhead and Supplies $\quad 50,000$

Embankments and General

10,000

Electricity, (Maintenance)

32,000

Concrete Features

12,000

Gates and Machinery

Heating

8,000

4,000

2,000

$\$ 584,000$

4,000

134,000

Total Non-Federal Annual Charges

$\$ 148,000$

TOTAL ANNUAL CHARGES

$\$ 732,000$ 
b. Alignment No. I. The barrier alignment normal to the center line of the river proved to be the shortest of those studied, but the construction of approach ramps through power plant yards and longer land walls would result in increased costs.

c. Alignment No. 2 (Selected Plan). The barrier alignment from Fox Point to Henderson Street would provide the most protection at the least overall cost.

d. Rock and earth fill barriers. Various structures were investigated using combinations of rock and earth fill with concrete appurtenant works. The rock and earth sections would provide adequate protection for the Providence area, but it was found that barriers of this nature would not lend themselves to easy access across the river or to the possible use of the barrier for docking purposes.

e. Concrete barriers. Studies indicated that concrete structures would be best suited for the site. These structures would not only provide the protection needed, but they would provide wharf space for shipping. The pumping station location at the east end of the barrier is located on the best foundation material. The eastern end location also made it possible to keep the warm water discharge from the power plants remote from the cooling water intakes.

f. Control of level of Providence River. A study was made for controlling the level of the Providence River upstream of the barrier either by (1) diversion of the woonasquatucket and Moshassuck Rivers into adjacent watersheds by means of a systern of open channels, or (2) discharge of the river flows through pressure conduits below the barrier.

LOWER BAY BARRIERS

\section{F-16. EAST BARRIER}

\section{a. Description and pertinent data.}

(1) The East Passage barrier would extend from Conanicut Island on the west to Newport Neck on the east. It would be oriented normal to the existing navigation channel and at a location suggested by the U. S. Navy. The barrier would contain an ungated navigation opening centered upon the channel. 
(2) The barrier would be of rock-fill construction; a section through this barrier would be trapezoidal in shape with a 20-foot top width, at elevation 22.0 feet above mean sea level, and with side slopes of 1 vertical on 2 horizontal on both the ocean and bay sides. The cap stones would consist of derrick stone of 20-ton minimum size. The cap stones would extend across the top and down both sides to an elevation 20.0 feet below mean sea level.

(3) This plan is based on an ungated navigation opening, 1,000 feet wide by 50 feet deep at mean low water. The size of the opening would be varied to coordinate with Navy requirements at the time of construction.

(4) Pertinent data on the East barrier structure are summarized below.

$\begin{array}{ll}\text { Type } & \text { Rock-fill } \\ \text { Top Ele vation, feet m.s.l. } & 22.0 \\ \text { Length, feet } & 3,200 \\ \text { Maximum Height, feet } & 187 \\ \text { Side Slopes } & 1 \text { on } 2\end{array}$

b. Lands and damages. The land requirements will include rights-of-way, maintenance areas, and easements. The construction of the barrier at the proposed site would require no relocation of utilities or near-by structures. The cost of lands and damages has been estimated upon the basis of current market values, and information obtained from local authorities.

F-17. WEST BARRIER

a. Description and pertinent data.

(1) The West barrier would be located some 600 feet south of Jamestown Bridge and would extend from Plum Beach on the west to Conanicut Island on the east. The barrier would be oriented normal to the existing navigation channel which lies between the two main piers of the bridge, and would contain an ungated navigation opening centered upon the channel. In addition to the navigation opening, a 10-foot wide by 10-foot high culvert in the shallow water at the west bank would provide free flow through the barrier to eliminate excess scum formation. The culvert could also be used as a small boat passage. 
(2) The barrier would be of rock-fill construction. It would be trapezoidal in shape with a 20-foot top width at elevation 22.0 feet above mean sea level and with side slopes of 1 vertical on 2 horizontal on both the ocean and bay sides. The cap stones would consist of derrick stone of 20 ton minimum size. The cap stones would extend across the top and down both sides to an elevation 20.0 feet below mean sea level.

(3) An ungated navigation opening, 400 feet wide by 40 feet deep at mean low water, would be provided.

(4) The highway across Round Swamp on Conanicut Island would be raised to 22 feet above mean sea level and protected by a stone facing.

below:

(5) The pertinent data for the West barrier are summarized

$\begin{array}{ll}\text { Type } & \text { Rock fill } \\ \text { Top Elevation, feet m.s.l. } & 22.0 \\ \text { Length, feet } & 7,100 \\ \text { Side Slopes } & 1 \text { on } 2 \\ \text { Maximum Height, feet } & 100 \\ \text { Top Width, feet } & 20 \\ \text { Navigation Opening } & \\ \quad \text { Width, feet } & 400 \\ \text { Depth, feet below m.l.w. } & 50\end{array}$

b. Lands and damages. Land requirements will include rightsof-way, land for relocation and maintenance areas, and shore-front easements. The construction of the barrier, at the site selected, would require no relocation of highways or utilities. However, modification of the existing highway across Conanicut Island would have to be made in order to meet the required land wall which follows the existing road alignment. The cost of lands and damages has been estimated upon the basis of current market values, field reconnaissance and information secured from local authorities.

F-18. TIVERTON BARRIER

a. Description and pertinent data.

(1) The Tiverton barrier and related dike system would extend along the south shore of the Island Park section of Portsmouth, thence across the Portsmouth-Tiverton Channel and continue in a southerly direction along the Tiverton shore. 
(2) The barrier would bo of rock and earth fill construction. The top width would be 15 feet and the side slopes 1 vertical on 2 horizontal. The land dikes, east and west of the barrier, would be similar in design, except that the side slopes would be $I$ on 3 on the land side and $I$ on 2 on the sea side. The crests of barrier and dikes woulc be at an elevation 20.0 feet above mean sea level.

(3) A gated navigation opening 100 feet wide and 30 feet deep at mean low water woulc be included. Sector gates would be used for closing the opening. summarized below:

(4) Pertinent data on the Tiverton barrier are

\section{Barrier}

Type

Top Elevation, feet m.s.I.

Length, foet

Maximum Height, feet

Side Slopes

Top Width, feet

Dike

Type

Top Elevation, feet m.s.l.

Length, feet

Maximum Height, feet

Top Width, feet

\section{Navigation Opening}

Type

Width, feet

Sill Elevation, feet below m.1.พ.

Top Elevation, feet m.s.I.
Rock and earth fill

20.0

912

82

1 on 2

15

Rock and earth fill 20.0

8,513

30

15

Sector gate with concrete abutment 100

30

20.0

b. Lands and damages. The land requirements would include rights-of-way, maintenance areas and easements. The construction of the barrier would involve no relocation of highweys or utilities. It would be necessary, however, to abandon portions of the roads south of Fountain Spring Avenue and Sakonnet Boulevard which now furnish access to the beach. 


\section{F-19. AVAILABLE MATERIALS}

Adequate unopened quarry sites are available for supplying derrick stone and quarry run rock for the Lower Bay barriers. Sand and gravel are available in sufficient quantities to provide the fill under the Fox Point barrier gravity section (see Appendix E).

\section{F-20. PLAN OF CONSTRUCTION}

The structures in the Lower Bay barriers would require about 3 years to construct, assuming good foundation conditions, and 4 years with unfavorable foundations. The construction schedule for each of the structures would be as follows:

a. East barrier. Before construction can be initiated on the East barrier, a more complete investigation of the foundation must be made. The first construction items would include the opening of quarry sites, access roads, and loading facilities. Placement of rock by floating equipment would be continuous through the 3 or 4-year construction period.

b. West barrier. The procedure for construction of the West barrier would be similar to that of the East barrier.

c. Tiverton barrier. Construction of the Tiverton barrier is based on dredging of the Portsmouth-Tiverton Channel, cofferdamming for the gate structure and appurtenances, placement of the rock and earth dikes, and building the access roads.

(1) During the first year, the channel would be dredged, the cofferdan and the concrete for the gate structures placed, and the barrier constructed across the channel.

(2) Completion of the gate structure, removal of cofferdam, installation of gates and equipment would be accomplished during the second year or early in the third year.

(3) Land dikes, access roads, and appurtenant works would be constructed concurrently with the barrier and the navigation gates.

\section{F-21. OPERATION AND MAINTENANCE}

a. East and West barriers. The barrier would require periodic maintenance in order that no disintegration of the structure should occur and navigation aids would be properly maintained. Quarry sites, 
used for supplying building materials, would be retained on a stand-by basis to insure a supply of repair materials.

b. Tiverton barrier. Operation of the barrier would involve the closing of the sector gates, stoplogging of openings in the dike, and patrolling the land side of the dikes. Personnel would be maintained on a stand-by basis for these operations and periodic maintenance.

\section{F-22. COST ESTIMATES}

The cost estimates for the Lower Bay barriers are based on the plan as recommended and with assumed favorable foundation conditions at the East barrier for the minimum amount and on less favorable foundation conditions at the East barrier for the maximum amount.

Details of the estimated minimum first costs of the Lower Bay barriers, based upon the recommended plan, assuming a foundation settlement of eight feet in the West barrier and a settlement of 20 feet in the East barrier, are given in Table F-5. Estimated minimum annual charges are given in $\mathrm{T}$ able $\mathrm{F}-6$.

Details of the estimated maximum costs due to a 50-foot settlement of the East barrier and to the addition of gates in the West barrier are shown in Table F-7. Estimated maximum annual charges are detailed in Table $\mathrm{F}-8$.

\section{F-23. ALTERNATIVE SITES}

a. General. Several alternative sites were studied in detail for the location of protective barriers throughout Narragansett Bay. A brief discussion of these sites is given below:

(1) South Street barrier. This site, just north of the Fox Point location, was studied and a barrier similar to that at Fox Point was considered. The small amount of savings in the cost of the structure over the Fox Point barrier when compared with the benefits ruled it out in favor of the Fox Point location.

(2) Fields Point barrier. A barrier made up of rock fill and earth fill sections with a large pumping station $(30,000$ c.f.s.) was considered. It would also have two gated navigation openings. The high cost of pumping made this site marginal. Buildup ruled the site out. 
(3) Conimicut Point barrier. This site was studied and 2 barrier made ur of rock fill, a large pumping station $(30,000$ c.f.s.) and a 400-foot gated navigational opening was considered. This site was ruled out by the high cost of pumping and buildup below the barrier.

(4) Middle Bay barrier. This site was studied and rockfill barriers closing off the East and West Passages were considered. This barrier would require navigation openings for both passages. This site was ruled out due to excessive buildup below the barrier.

(5) Sakonnet River barriers. In addition to the selected Tiverton barrier, other sites at Black Point, Sandy Point, McCurry Point, and the Hurmocks were studied. These were more costly than the plan selected, without comensurate increase in benefit. 


\section{TAELE F-5}

ESTTMATED FIRST COSTS - Minimum Amount

(1956 Price Level)

LOWER BAY BARRIERS - NARRAGANSETT BAY

Item Quantity Unit Price $\underline{\text { Amount }}$ Total

EAST BARRIER

Access Roads

Rock Fill

Rock Fill

Contingencies

Engineering and Design

Supervision and

Administration

Construction Cost
1 job L.S. 50,000

4,371,000 Cu.Yd. $\$ 6.00 \quad 26,226,000$

$2,429,000$ Cu.Yd. $5.00 \quad 12,145,000$

$\$ \frac{12,14,000}{38,4,21,000}$

L.S. $\quad 6,149,000$

L.S. $2,710,000$

L.S. $\quad 2,800,000$

WEST BARRIER

Access Roads

Rock Fill

Culvert

Land Wall (road)

Contingencies

Engineering and Design

Supervision and

Administration

Construction cost

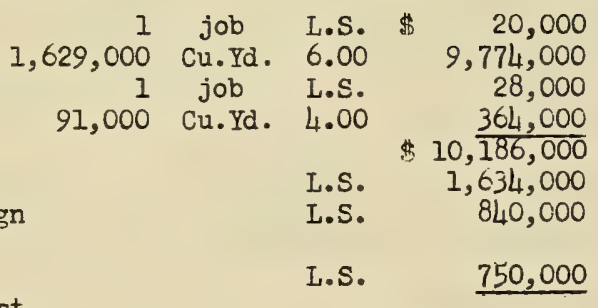

$\$ 13,410,000$

TIVERTON BARRIER

Dike and Barrier

Site Preparation

Excavation

Earth Fill

Rock Fill

Concrete

Miscellaneous Facilities

\begin{tabular}{rcrr}
1 & job & L.S. & $\$$ \\
19,000 & Cu.Yd. & 2.00 & 2,000 \\
570,500 & Cu.Yd. & 2.00 & $1,14,000$ \\
85,000 & Cu.Yd. 10.00 & 850,000 \\
446 & Cu.Yd. 65.00 & 29,000 \\
I & job & L.S. & 217,000 \\
\hline & & & $2, \frac{277,000}{277}$
\end{tabular}


TABLE F-5 (continued)

\section{ESIINATED FIRST COSTS - Minimum Amount (1956 Price Level) \\ LOWER EAY BARRIERS - NARRAGANSETT BAY}

\section{Item}

Quantity Unit $\begin{aligned} & \text { Unit } \\ & \text { Price }\end{aligned}$

Amount

Total

Navigation Gates

Cofferdam

Dewatering

Dredging

Concrete-Structural

Concrete-mremie

Gates and Equipment

Fender Guides

Navigational Aids
1 job L.S.

1 job L.S.

6,700 Cu.Yd. $\$ 1.50$

6,160 Cu.Yd. 65.00

6,670 Cu.Yd. 30.00

I job L.S.

I job L.S.

1 job L.S.

Subtotal

Contingencies

Engineering and overhead

Supervision and Administration

Construction Cost

L.S.

L.S.

I.S.
286,000
5,000
10,000
401,000
200,000
704,000
25,000
6,000
$1,637,000$
$3,914,000$
636,000
450,000
400,000

\$ $5,400,000$

$\$ 68,890,000$

\$. $\begin{array}{r}10,000 \\ 10,000 \\ 90,000 \\ \hline\end{array}$

Iands and Damages, East Earrier

Lands and Damages, west Barrier

Lands and Damages, Tiverton Barrier

Total Lands and Damages

TOTAL FIRST COST - LOWER BAY BARRIERS

(Minimum Amount)

Estimated first cost to J. S.

Estimated first cost to local interests

(1) Includes local cash contribution of $\$ 1,617,000$ representing the estimated present worth of a future annual cost of $\$ 57,000$ to the U. S. for operation and maintenance of the project, and an estimated cost of $\$ 110,000$ for lands, rights-of-way, relocations and damages to be borne by local interests. 


\section{TABLE F-6 \\ ESTTHATED ANNUAL CHARGES - Minimum Amount \\ (1956 Price Level) \\ LOWER BAY EARRTERS - NARPAGANSETT BAY}

Federal Investment

Total Federal First Cost

Interest during Construction

$\$ 67,273,000$

$\underline{2,527,000}$

\$4 $69,800,000$

Federal Annual Charges

Interest on Federal Investment

$$
(2-1 / 2 \%)
$$

Amortization (50 years)

Maintenance and operation

\begin{tabular}{lr} 
Quarry and Plant Maintenance & 5,000 \\
Embaniment and General & 40,000 \\
Concrete Features (Tiverton) & 2,000 \\
Gates \& Machinery (Tive, & 1000 \\
\hline
\end{tabular}

$\$ 1,742,000$

715,000

Quarry and Plant Maintenance \$

Embankment and General

Gates \& Machinery (Tiverton)

Total Federal Annual Charges

$\underline{57,000}$

$\$ 2,514,000$

Non-Federal Investment

Contributed Funds

Lands and Damages

Interest during Construction

Total Non-Federal Investment

Non-Federal Annual Charges

Interest on Non-Federal Investment $(2-1 / 2 \%)$

Amortization ( 50 years)

Estimated Tax Losses

Total Non-Federal Annual Charges

TOTAL ANNUAL CHARGES
\$ $1,617,000$

110,000

$\underline{65,000}$
$\$ 1,792,000$

* 45,000

18,000

$\underline{3,000}$

\$ 66,000

$\$ 2,580,000$ 


\section{TABLF, F-7}

ESTTMATED FIRST COSTS - Maximum Amount

(1956 Price Level)

LOWER BAY BARRTERS - NARRAGANSETT BAY

Item Quantity Unit Price $\underline{\text { Unit }}$ Prount

EAST BARRTER

Access Roads

Rock Fill

Rock Fill

Contingencies

Engineering and Design

Supervision and Administration Construction cost
1 Job L.S. \$ 50,000.

$4,894,000$ Cu.Yd. $\$ 6.00 \quad 29,364,000$

$3,924,000$ Cu.Yd. $5.00 \quad \frac{19,620,000}{49,034,000}$

L.S. $\quad 7,356,000$

L.S. $\quad 3,280,000$

L.S. $\quad 3,090,000$

$\$ 62,760,000$

WEST BARRIER

Access Roads

Rock Fill

Land WaII

Culvert

Navigation Gates

Sluice Gates

Contingencies

Engineering and Design

Supervision and Administration

Construction cost

\begin{tabular}{|c|c|c|c|}
\hline \multirow{2}{*}{\multicolumn{4}{|c|}{20,000}} \\
\hline & & & \\
\hline 06,000 & Cu.Yd. & 6.00 & $6,636,000$ \\
\hline 91,000 & $\mathrm{Cu} . \mathrm{Yd}$. & 4.00 & 364,000 \\
\hline 1 & job & L.S. & 28,000 \\
\hline 1 & job & L.S. & $14,000,000$ \\
\hline 1 & job & L.S. & $9,200,000$ \\
\hline & & L.S. & $4,537,000$ \\
\hline & & L.S & $3,175,000$ \\
\hline & & & $2,770,000$ \\
\hline
\end{tabular}

$\$ 40,730,000$

TIVERTON BARRIER

Construction cost (From Table F-5)

$\underline{5,400,000}$

$\$ 108,890,000$

Total Construction Cost

Total Lands and Damages (From Table F-5)

110,000

$\$ 109,000,000$

TOTAL FIRST COST - LOWER BAY BARRIERS

(Maximum Amount)

Estimated First Cost to U. S.

进105, 203,000

$3,797,000(1)$

Estimated First Cost to Local Interests

(1) Including local cash contribution of $\$ 3,687,000$ representing the estimated present worth of a future annual cost of $\$ 130,000$ to the U.S. for operation and maintenance of the project, and an estimated cost of $\$ 110,000$ for lands, rights-of-way, relocations, and damages to be borne by local interests. 
TABLE F-8

ESTIMATED ANNUAL CHARGES - Maxinum Amount (1956 Price Level)

LOWER BAY BARRIERS - NARRAGANSETT BAY

Federal Investment

Total Federal First Cost Interest during construction Total Federal Investment

$\$ 105,203,000$

$\underline{5,260,000}$

$\$ I I 0,463,000$

Federal Annual Charges

Interest on Federal Investment

$$
(2-1 / 2 \%)
$$

Amortization ( 50 years)

Maintenance and Operation

Quarry and Plant Maintenance

Embanknent and General

Concrete Features

Gates (Tiverton)

Navigation Gate (wiest Barrier)

Sluice Gates (West Farrier)

Total Federal Annual Charges
\$ $2,760,000$

$1,133,000$
5,000

40,000

2,000

10,000

57,000

$\underline{16,000}$
130,000

$\$ 4,023,000$

Non-Federal Investment

Contributed Funds

Lands and Damages

\$5 $3,687,000$

110,000

190,000

Total Non-Federal Investment

$\$ 3,987,000$

Non-Federal Annual Charges

Interest on Investment

Amortization

Estimated Tax Losses

Total Non-Federal Annual Charges

$\$ \quad 100,000$

41,000

$\underline{3,000}$

TOTAL ANNUAL CHARGES

\$144,000

$\$ 4,167,000$ 

APPENDIX G

PUBLIC HEARINGS AND VIEWS OF OTHER AGENCIES 



\section{APPENDIX G}

PUBLIC HEARINGS AND VIEWS OF OTHER AGENCITS

\section{G-1. GENERAL}

This appendix presents a digest of public hearings and includes available letters and statements indicating the views of other agencies on the plans of protection. In some cases, studies of other agencies are in progress and their reports are not yet available.

\section{G-2. DIGEST OF PUBLIC HEARINGS}

Public hearings were held by the Division Engineer, in Providence and Newport, Rhode Island, and Fall River, Massachusetts, on 1,2, and 3 October 1956, respectively. The hearings were held to give all interested parties an opportunity to express their views concerning the character and extent of hurricane protection desired, and the need and advisability of its execution. Also included is a digest of correspondence from local interests pertaining to the recommended plan of protection.

\section{G-3. LETTER OF COMNENT}

a. Rhode Island Hurricane Survey Advisory Committee. Letter signed by Henry Ise', Chairman, Rhode Island Hurricane Survey Advisory Committee, dated 24 September 1956, outlining the committee's viewpoints, is included.

Gal4. LETTERS OF COMMENT ON POLLUTION

a. U.S. Public Health Service. Studies are in progress and report will be furnished shortly after 1 March 1957. Letter signed by Mr. Lester M. Klashman, dated 7 February 1957, is included.

b. Rhode Island Public Health Service. Statement by Mr. Walter J. Shea, Chief, Division of Sanitary Engineering, Rhode Island State Department of Health, is included.

c. Massachusetts Department of Public Health. Letter signed by the Honorable Christian Herter, Governor of the Commonwealth of Massachusetts, dated 13 December 1956, is included. 
a. U.S. Fish and Wildlife Service, As part of a continuing study, the Boston, Massachusetts Regional office of this agency furnished "A preliminary Report on Fishery Resources in Relation to the Hurricane Damage Control Program for Narragansett Bay and Vicinity, Rhode Island and Massachusetts", dated October 1956, consisting of 34 pages, 2 tables, and 16 charts and photographs. The following topics are discussed with respect to the changes that might be caused in the bay's fish and shellfish resources by hurricane protection measures; (1) the sport fishing inventory, (2) the Quahog study, (3) the Hard Clam fishery, (4) sampling methods, (5) distribution, (6) density, (7) summary of distribution and density data, (8) relation to barriers, (9) further research needed, (10) the bottom fauna study, the winter flounder study, and the commercial fisheries inventory. An abstract of the Conclusions and Recommendations of subject report is attached.

b. Massachusetts Division of Marine Fisheries. Comments on wildlife are contained in the letter by Governor Herter, referred to in paragraph $\mathrm{G}-1 / \mathrm{C}$.

G-6. LOCAL COOPETRATION

a. The Honorable Dennis J. Roberts, Governor, State of Rhode Island. Letter dated 2 February 1957 is included.

b. Governor, Commonwealth of Massachusetts. As yet no comment has been received on the procosed plan of protection.

c. The Honorable Walter H. Reynolds, Mayor of Providence. Letter dated 29 January 1957 is included. 


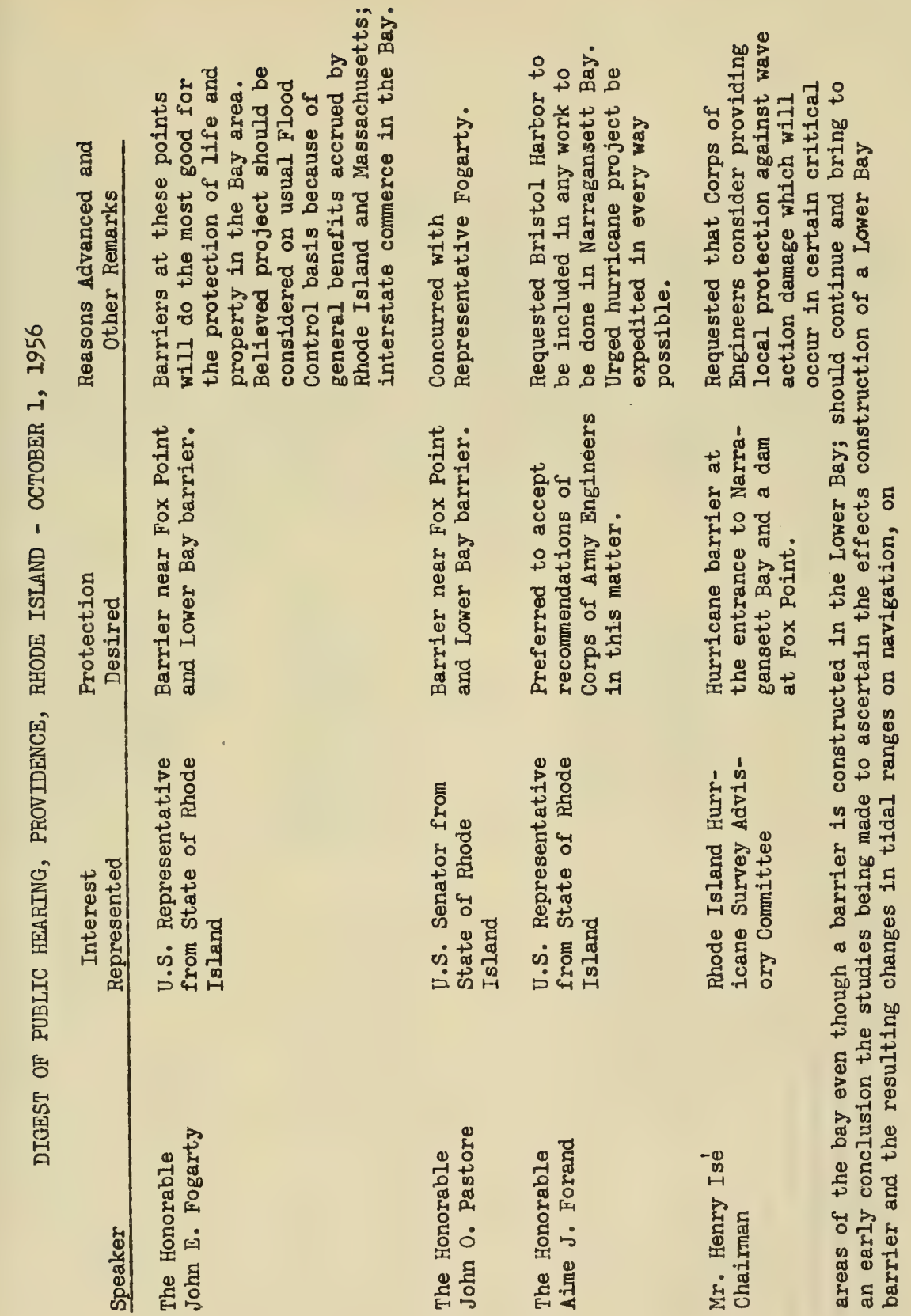




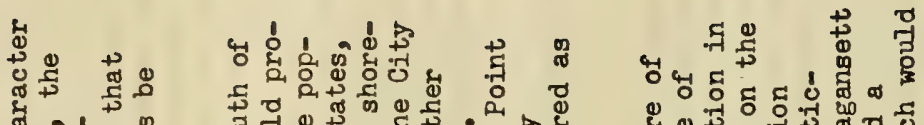

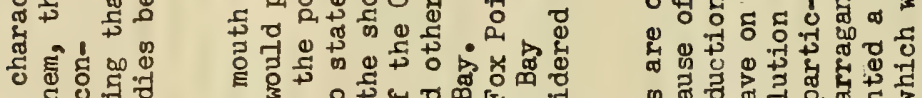
†ं न

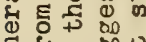
5. कo

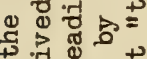

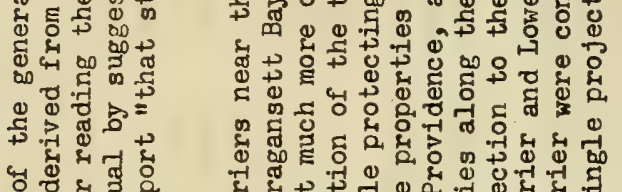
\%

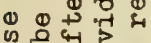

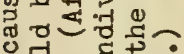

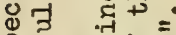
잉 is 1 . o. 골 0.

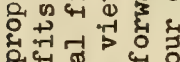
किष्य

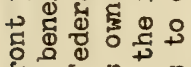
क्षे 0 is 证 क力 के 5 on ₹

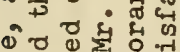
भ व 7ี 0

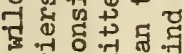

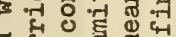

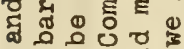
舟出象

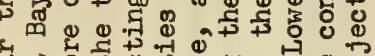

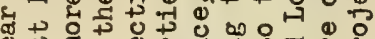
눙

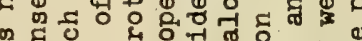

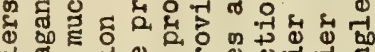

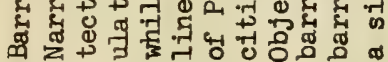

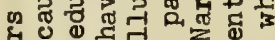
क o 1

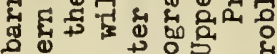

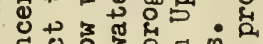
甾

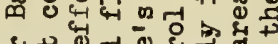

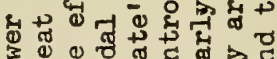

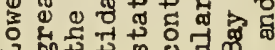
$\begin{array}{ll} & \\ & \end{array}$

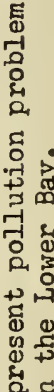

密 总

की द्व

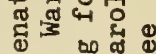

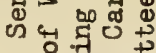

+3 ते है

点。

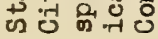

窝

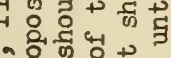

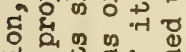

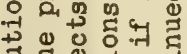

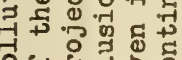

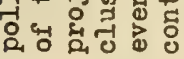

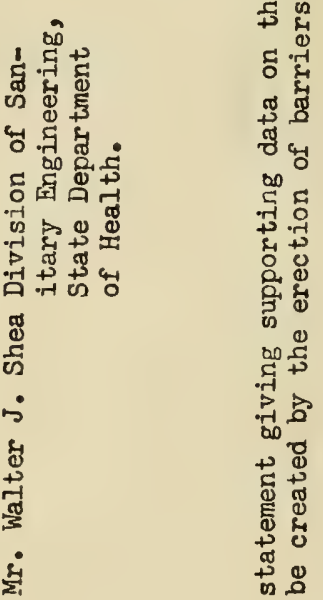




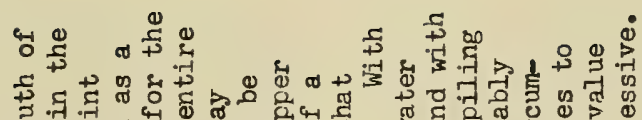

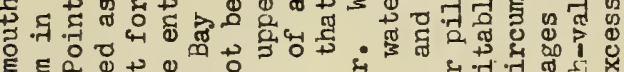

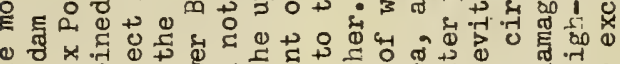
†

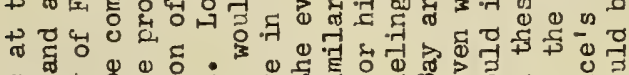
क

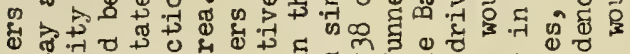

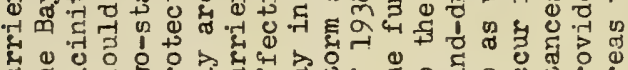

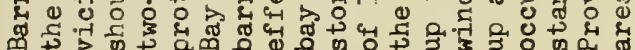

ชั 究 द्व का क भा ఖ †

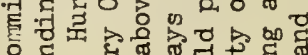

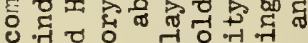
๓ न1

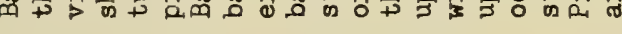

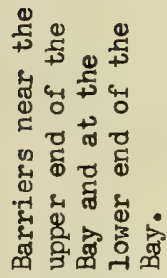

น

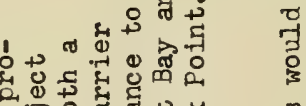
-

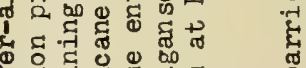
今.

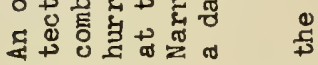

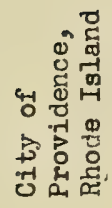

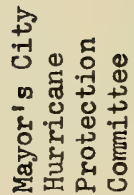

भ

乐雪

בี

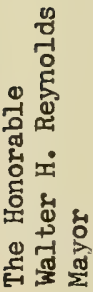




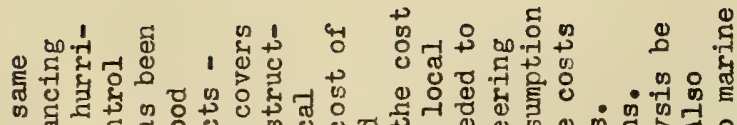

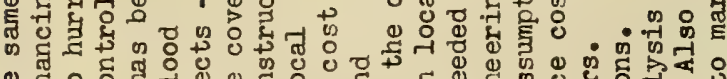

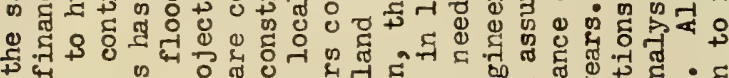

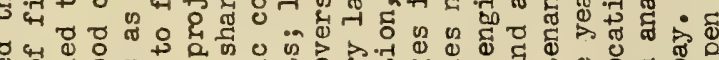

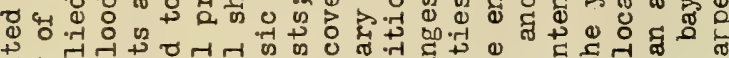

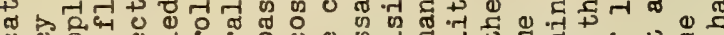
ठ워 0 ब.

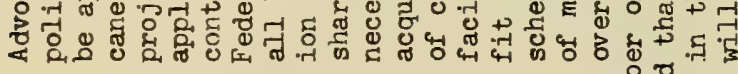

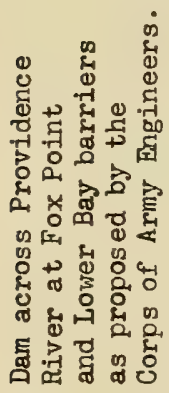

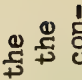

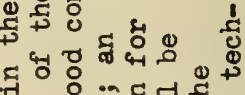

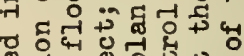
\&. 응 论

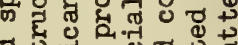

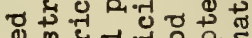
0 为

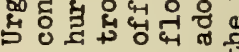

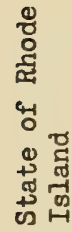

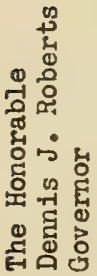

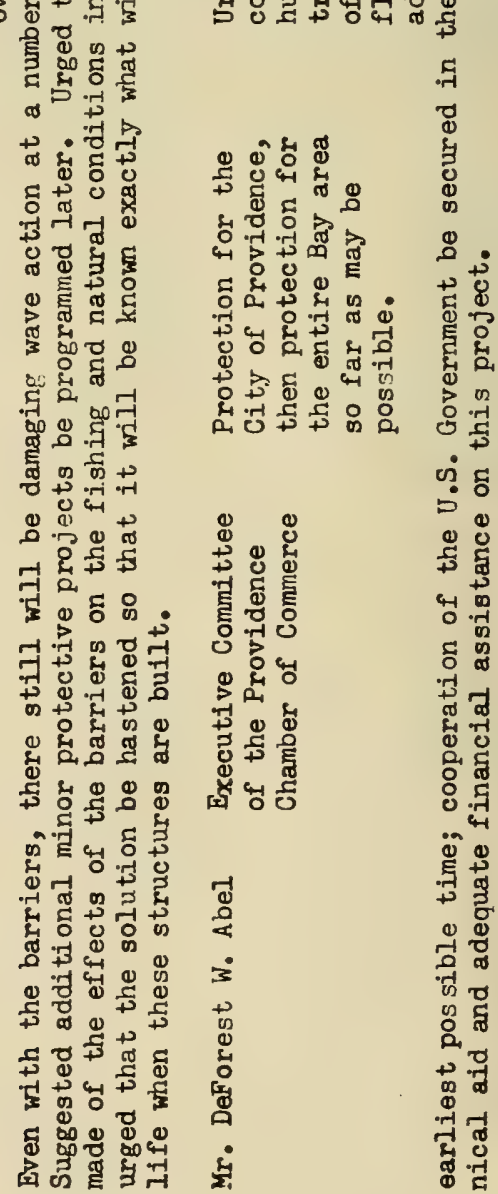


¿.

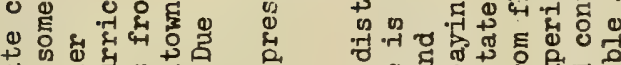

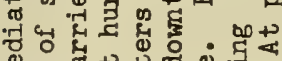

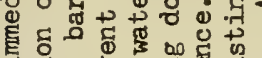
न o

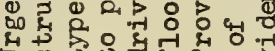

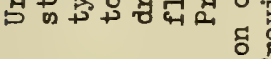

$$
\text { 密 }
$$

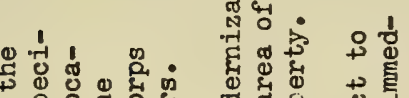

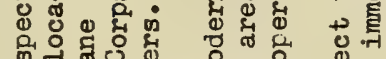
क कान की

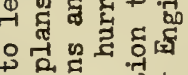
की 7 .

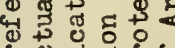

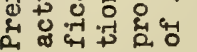

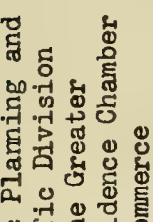
년현

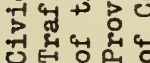

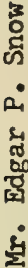

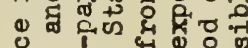
동 00

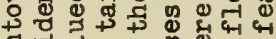
है on

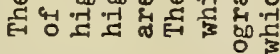
동

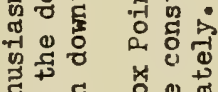

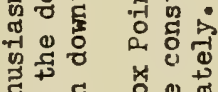

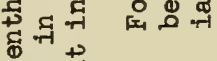
离范

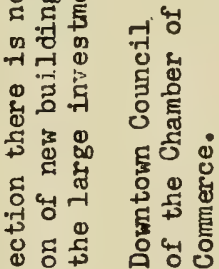

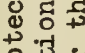

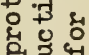
造 엉 密客 果

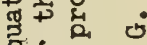

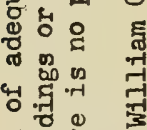
尊贯递 \$

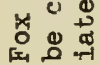

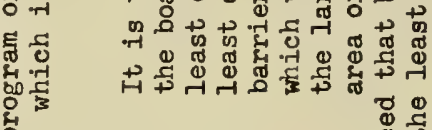
台。 遍 政

密

ro

。

敋器

岁。 है

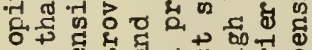

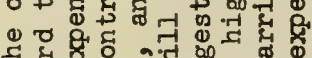

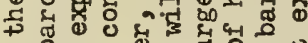
列

o :

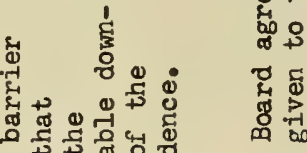
का +क 岁题要

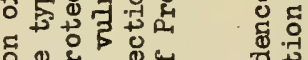
年

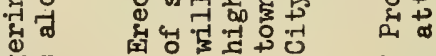
政政 岁 요 용 吅 8 8 क

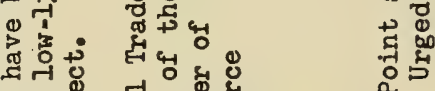
o

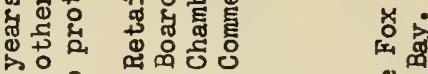
(1)

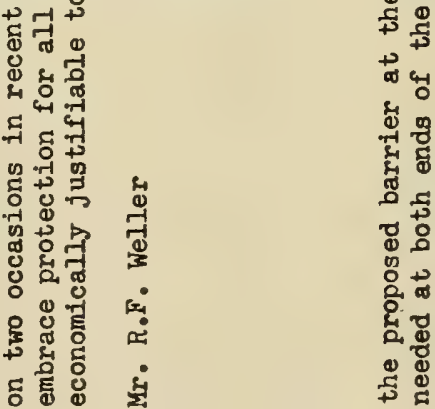




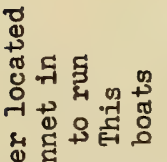

.

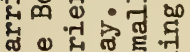

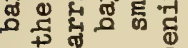

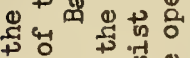
年 (1) की n की 0 10 ๙ 0

- 5 o $4 \vec{b}$

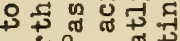
$\rightarrow$ \& 0 . $\rightarrow$

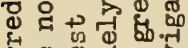

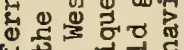
$4+4$ ता तो क $+\frac{1}{4}$ 웅 당

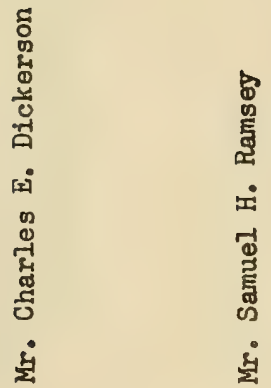

m

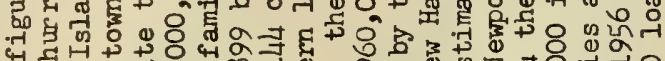

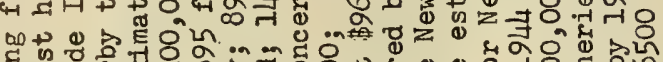
.

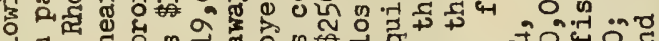
대 5 व 4 e † 万 न्-

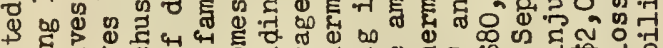
द. न

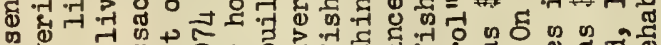
\% $\sim-1$ के

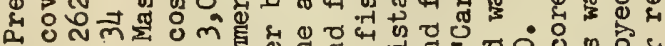
4

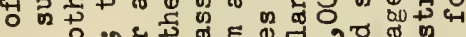

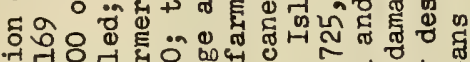

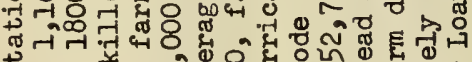
ثै. न

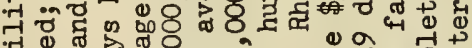
范

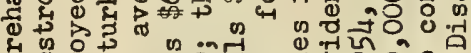
4 员

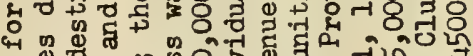
4

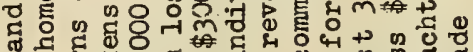

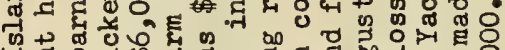
म ๆ โ

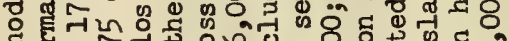
द्व ศิ

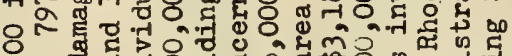
ํํ

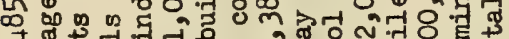
毛息范 ᄁु

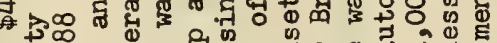
+

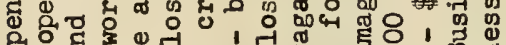

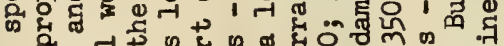

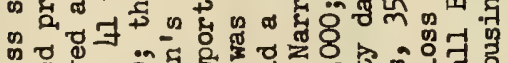
\% 웡 4 क्ष क्ष

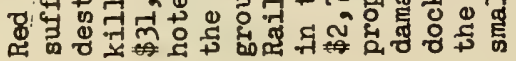

*

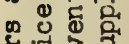
क्षे के जे 蝶僁能 ० 2 ज

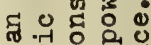
त्रिक्यु 0 . का नु के क्षे क्ष क्ष क्ष 0 \& क्ष $\rightarrow 0.7$ मृ 이역 म. न्न द्या है

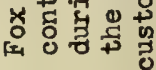

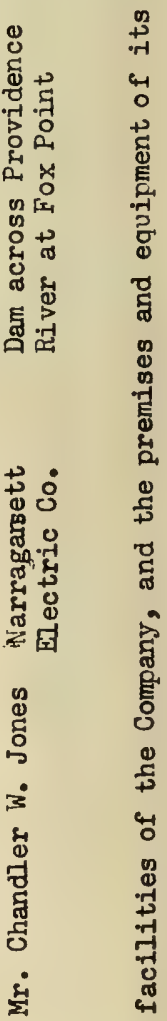


đิ

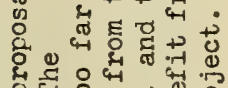

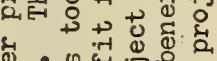

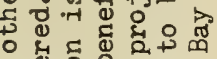
舟

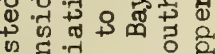

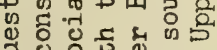
$8,000 \%$ .

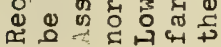

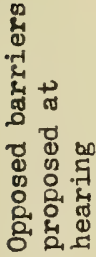

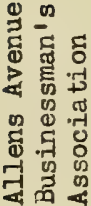

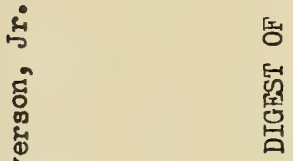

苗

i

医

帠

일

a मे

空

名

๓் ฮั

®

है

무

-

$\dot{\Sigma}$

留

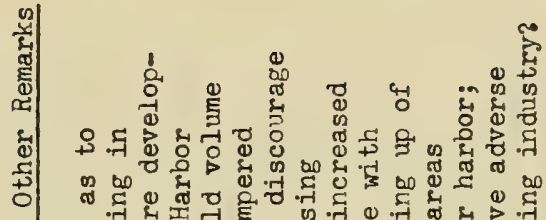

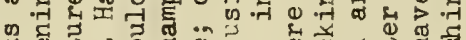
कृ

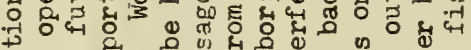

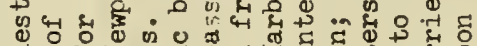

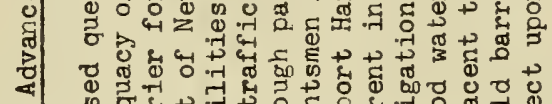

व्र ज 당 न्न

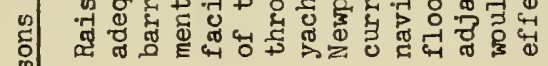

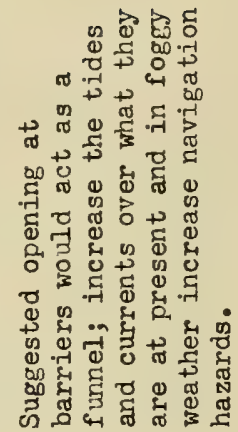
รี ช

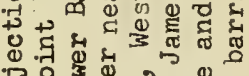

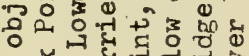

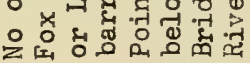

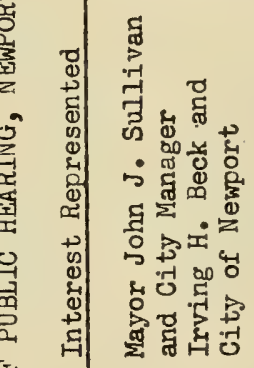

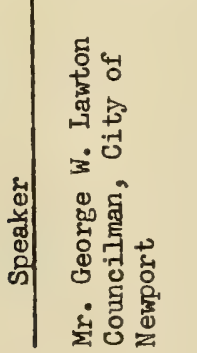



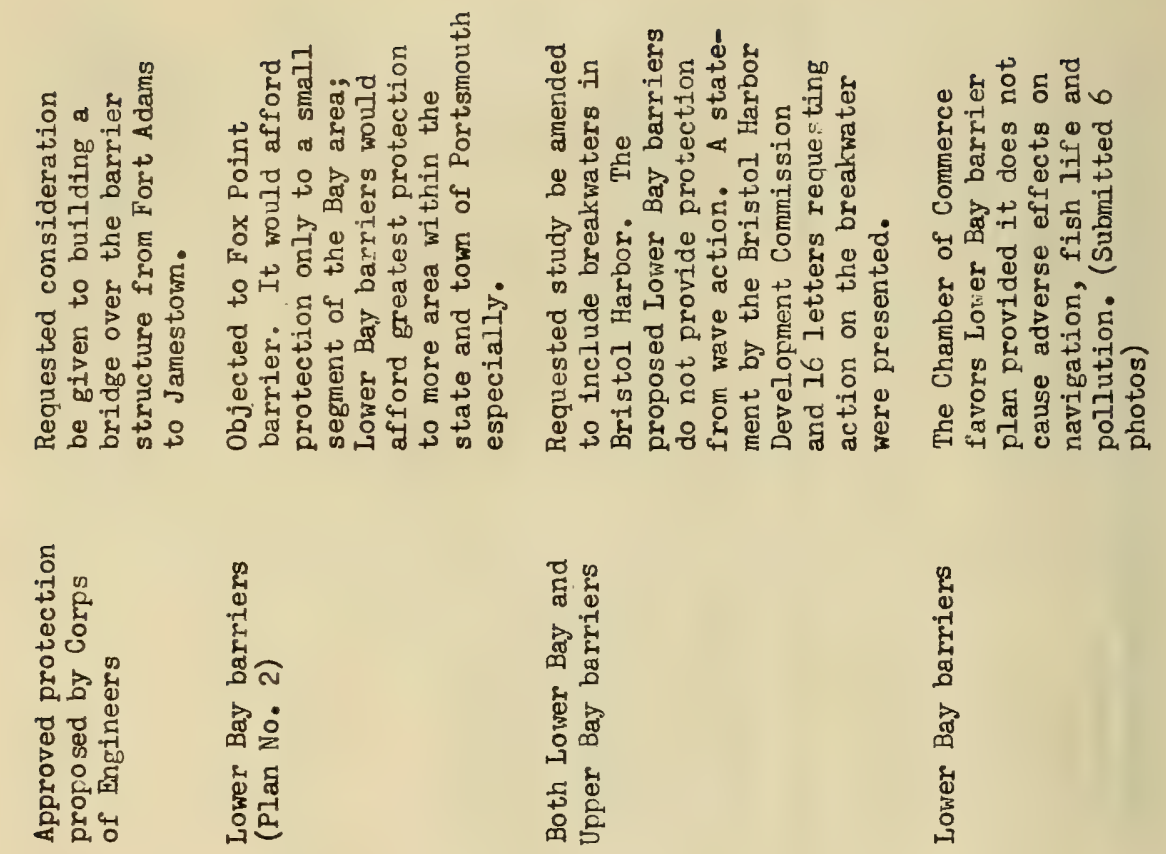


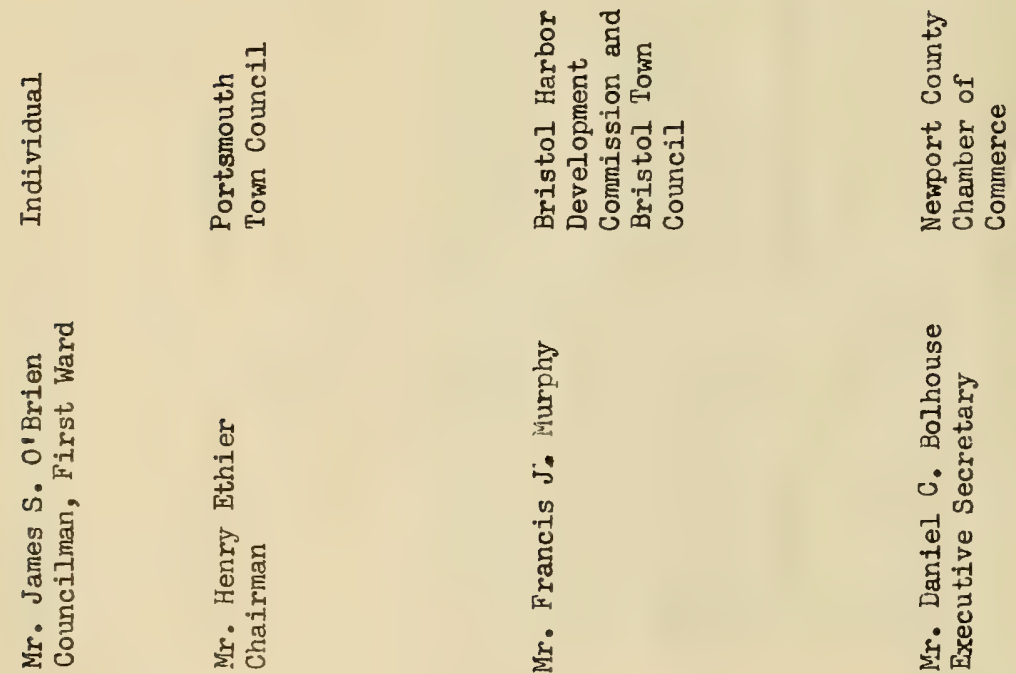


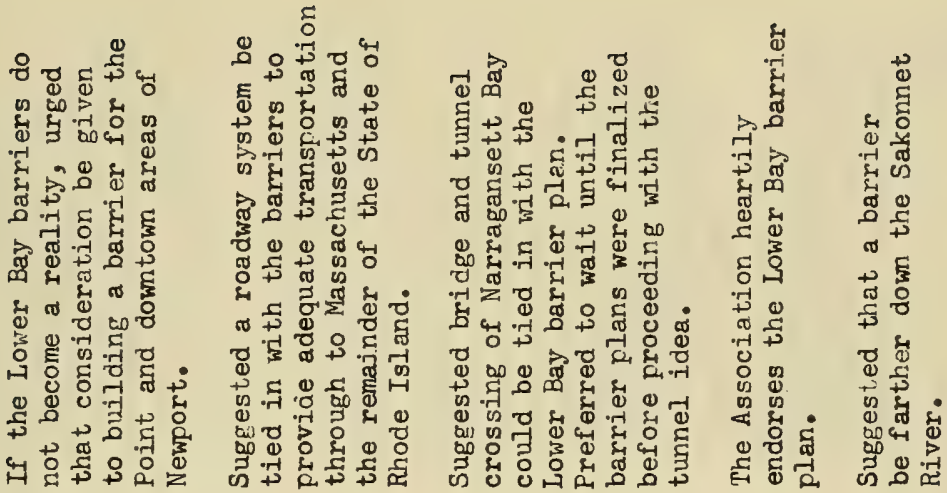

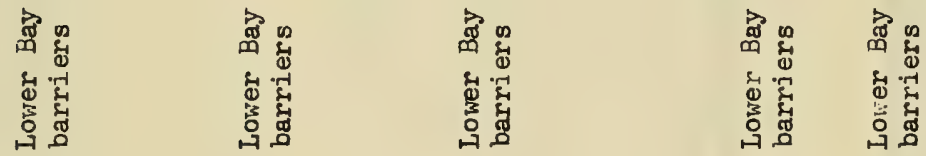

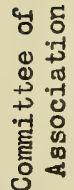

\begin{tabular}{|c|}
\hline 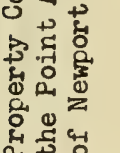 \\
\hline
\end{tabular}

焉

مं

$\infty$

गु

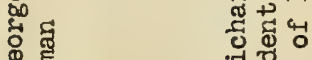

ठ

홀옹
귤

兽

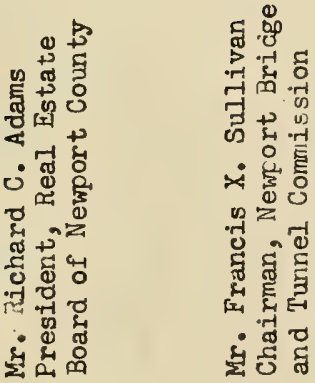

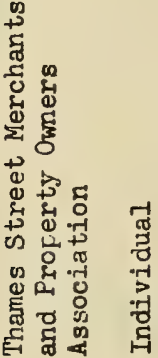

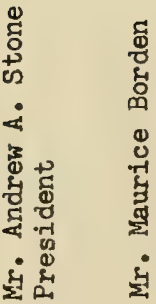




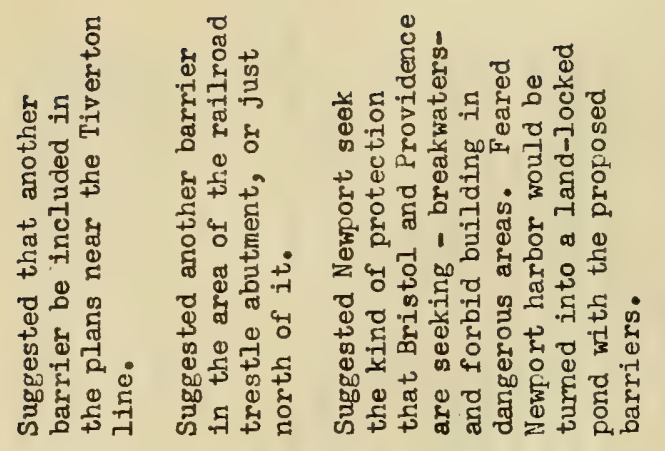

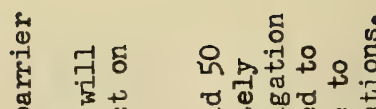
可 워 कैष +5 क्त क्ष

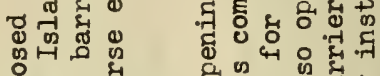

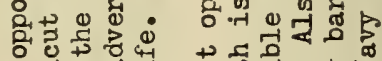

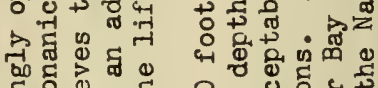
bo

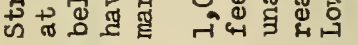
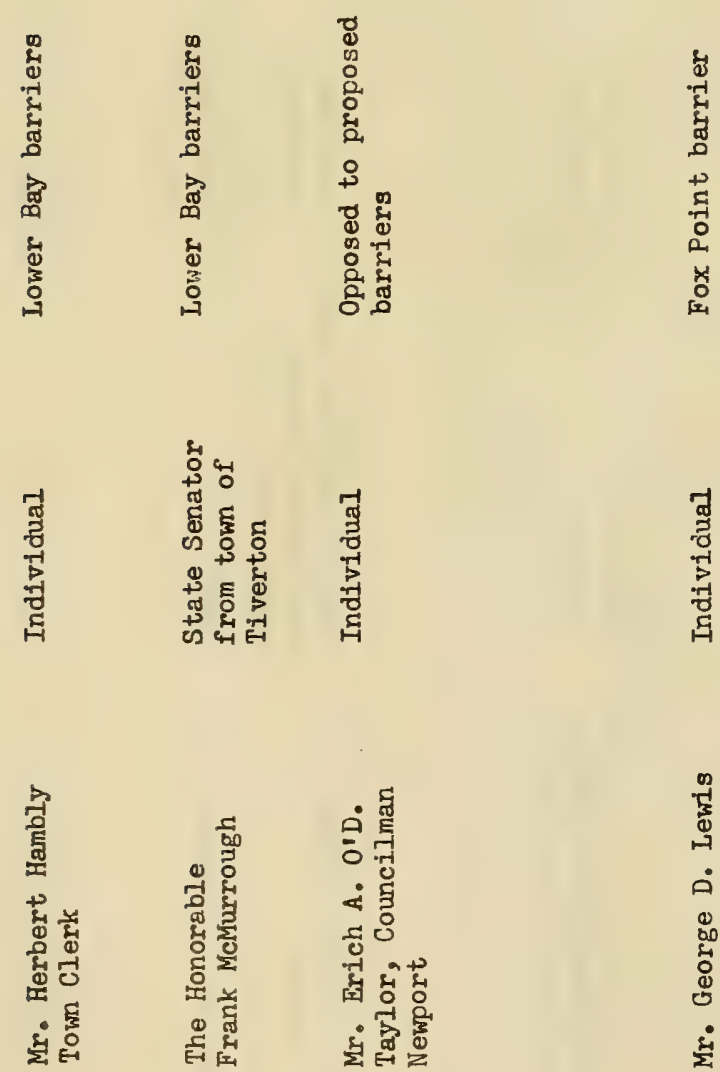

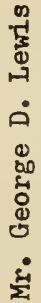

곯

ปే


$c$
0
0

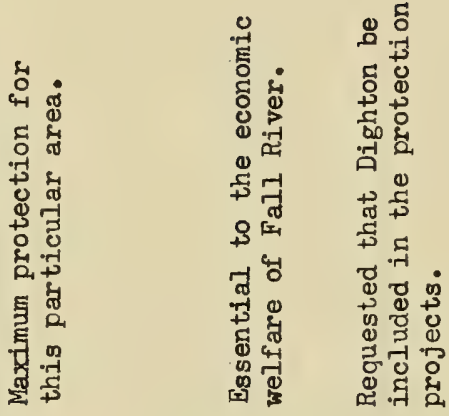

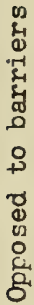

นั

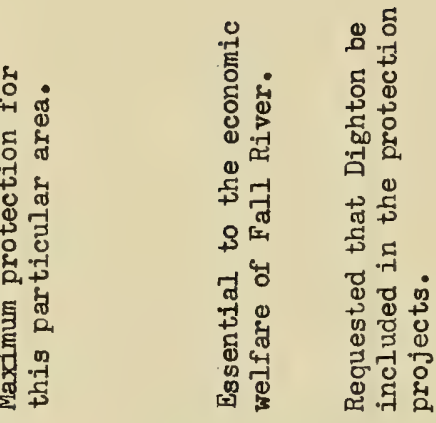

के

ช.

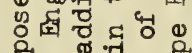

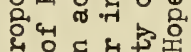
คै० 䟢 क्ष

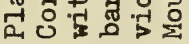

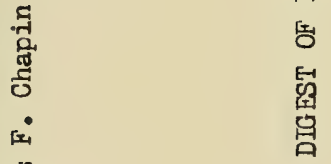

是

0

诜

品

동

1

宣

造

幽密

ฮิ

4 ํㅓㅇ ⿷匚

영 앵

8 \& 2

造

윴

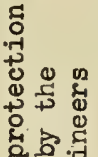

फ

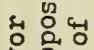

品

ॠ

岳

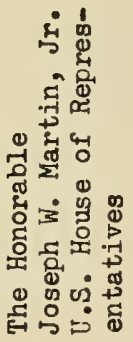

出 告

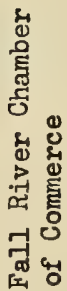

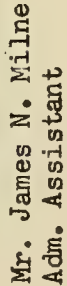

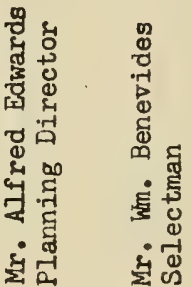

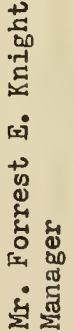




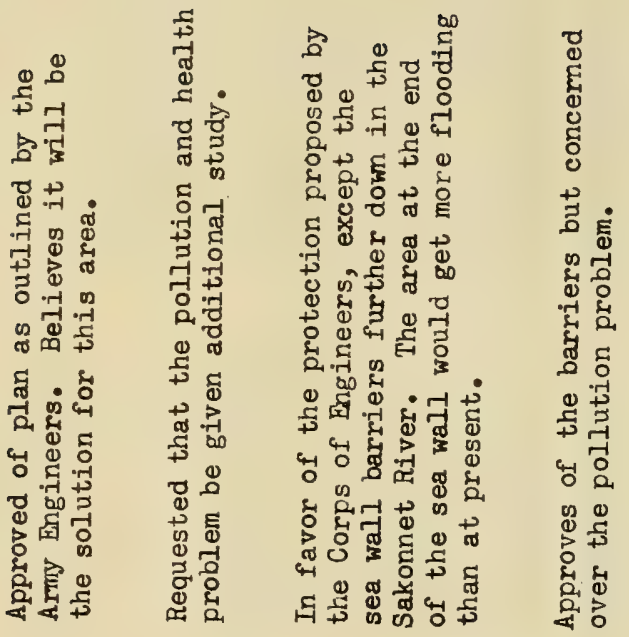

옹

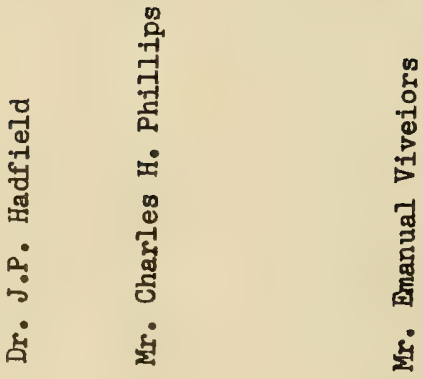


象 मै

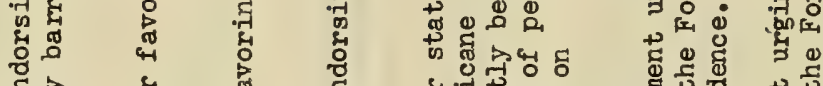

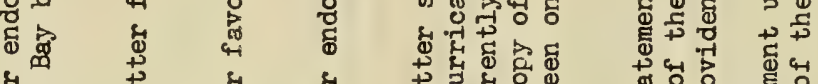

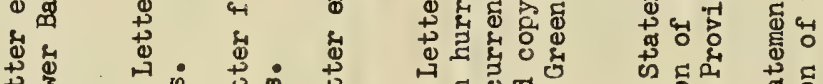

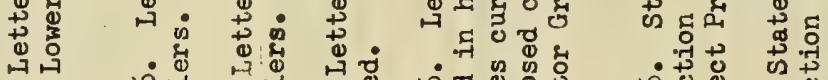

○्ठ นू.

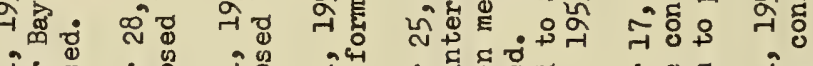

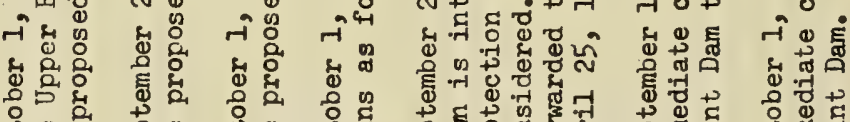

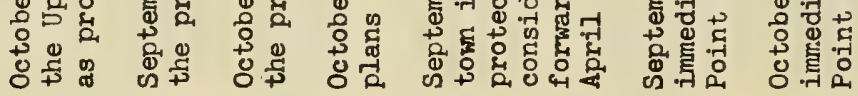

今ต

四 员

刍然

曽

응

of c口

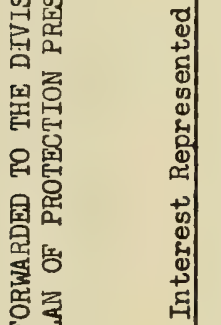

究 ?ृ

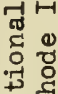

范

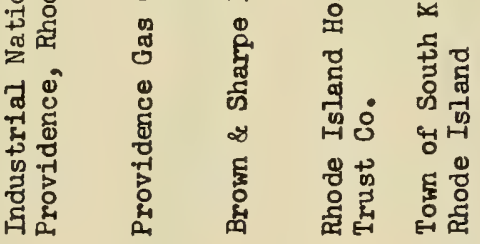

D

है

起宫

$\mathrm{E}$

约牙

悹

ชิ

焉总

ซึ

ख्य

的骂

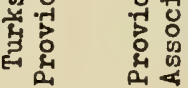

窝

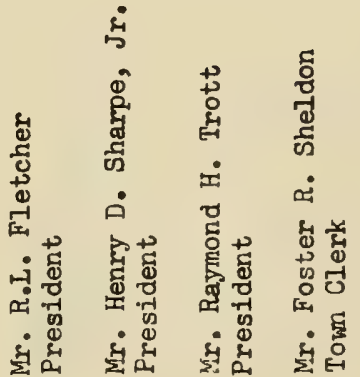

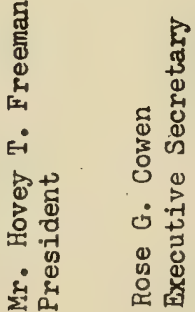




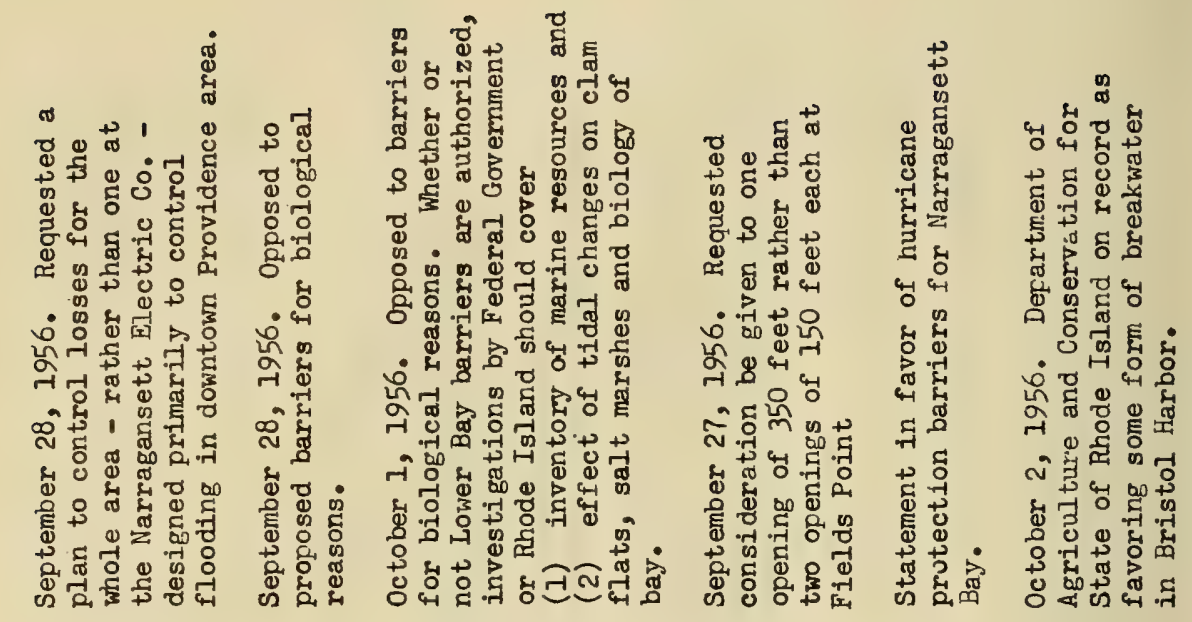
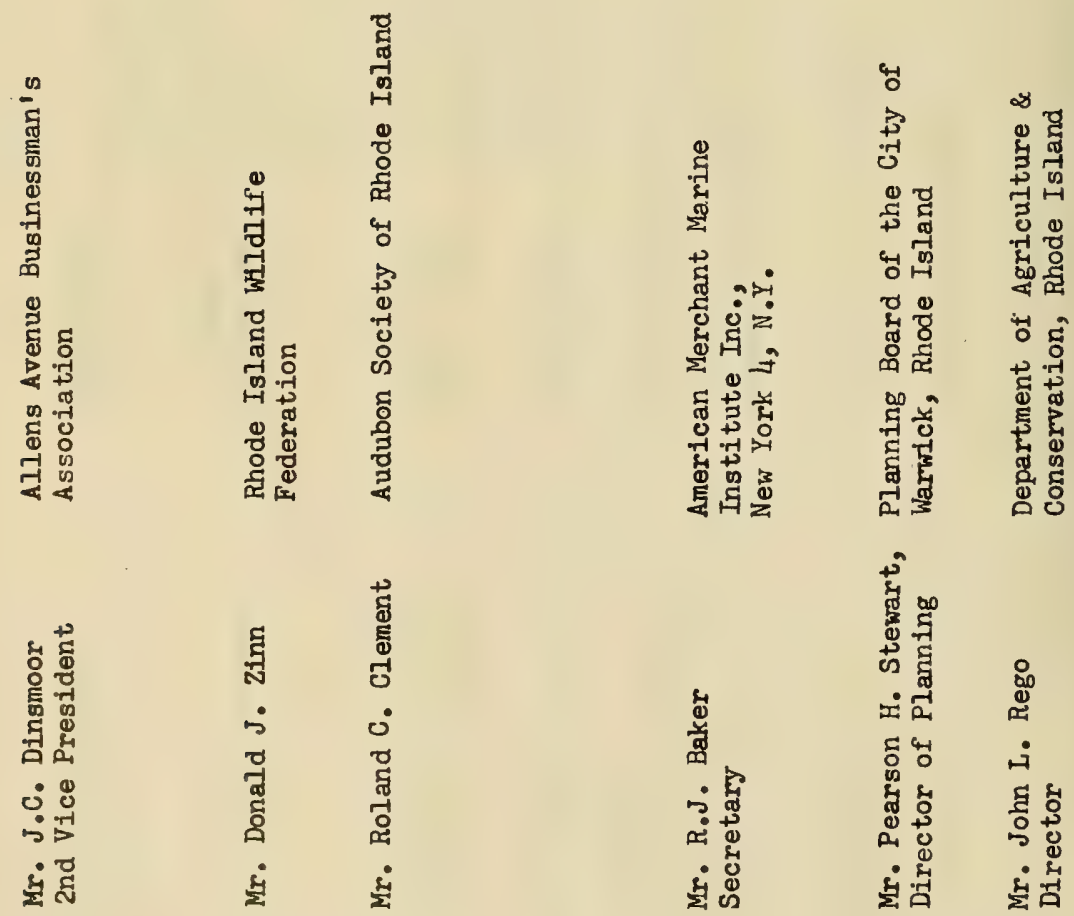


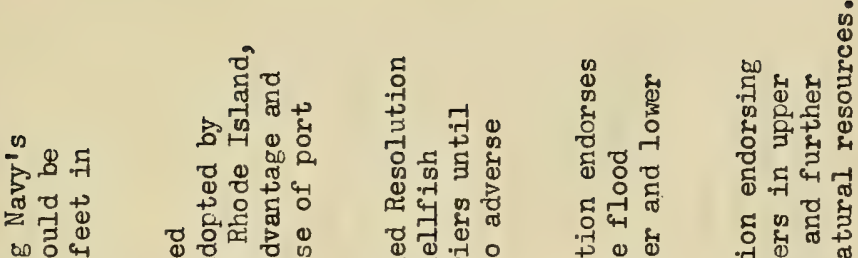

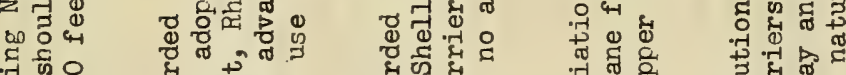

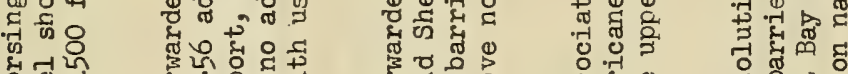

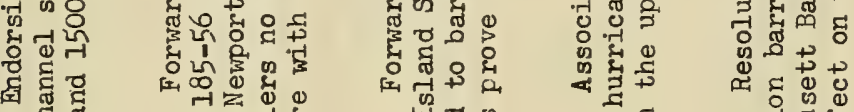

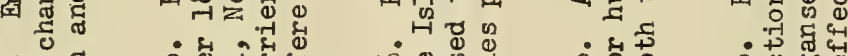

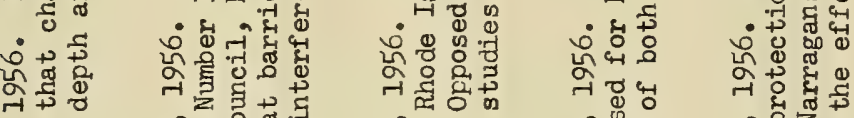

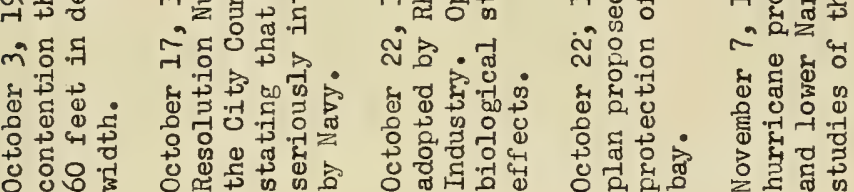
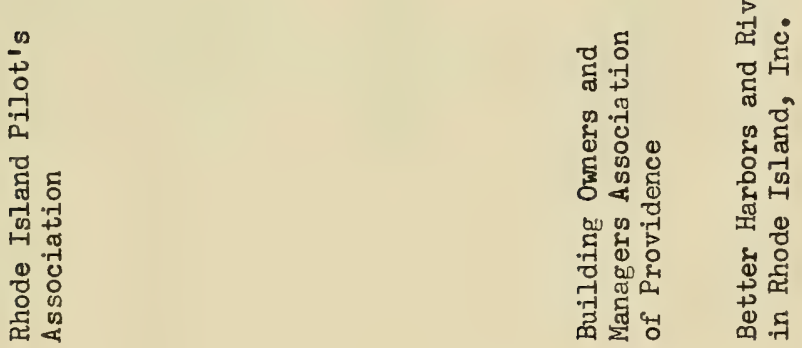

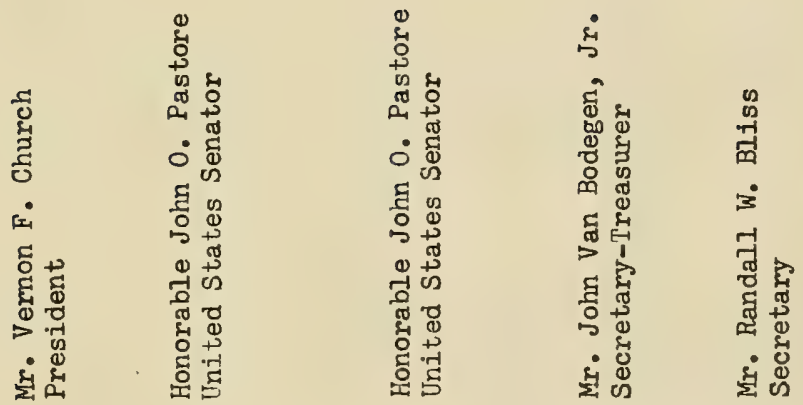



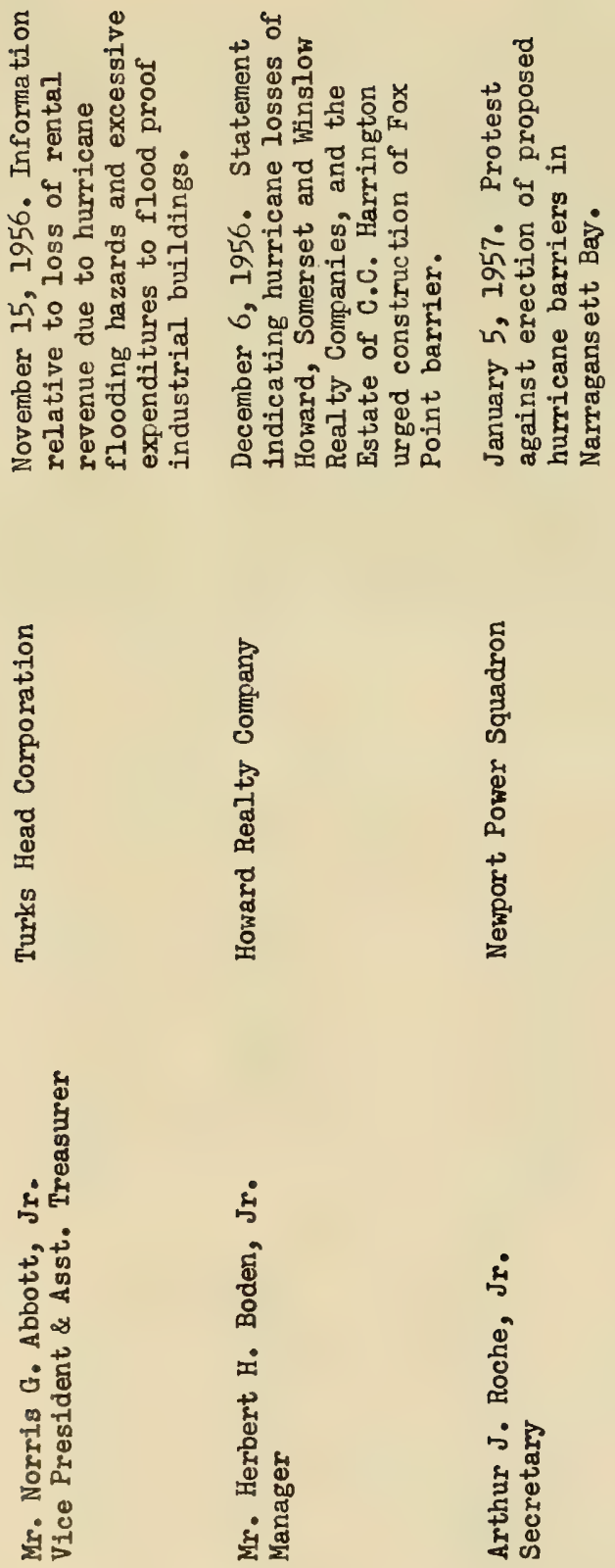


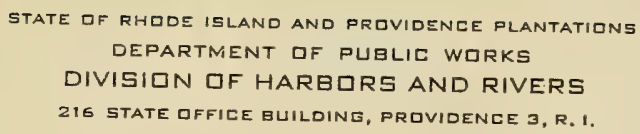

The Honorable Dennis J. Roberts

Governor of the State of Rhode Island

State House

Providence, Rhode Island

My dear Governor:

At an executive meeting held at the State House on Tuesday evening, September 18, immediately after its fourth general meeting, the Rhode Island Hurricane Survey Advisory Committee voted to inform the Corps of Lingineers, U. S. Army, through General Robert J. Fleming, Jr., Division Engineer, at,Boston, Massachusetts, that the committee is in favor of the following:

(a) The construction of a hurricane barrier at the entrance to Nerragansett Bay and a dam at Fox Point.

(b) The committee urge the Corps of Engineers to consider providing local protection against wave-action damage which will occur in certain critical areas of the bay even though hur.icano barriers are constructed as suggested above.

(c) That the Corps of Engineers should continue and bring to an early conclusion the studies now being made to ascertain the effects construction of a lower bay barrier and the resulting change in tidal ranges may have on fish and wildlife, on pollutioh, on navigation, and on certain shorefront properties.

(d) Because of the general character of the proposed barriers and the widespread benefits which would be derived from them, the comnittee feels that the proposed hurricane projects should be considered eligible for Federal government financing.

Respectfully yours,

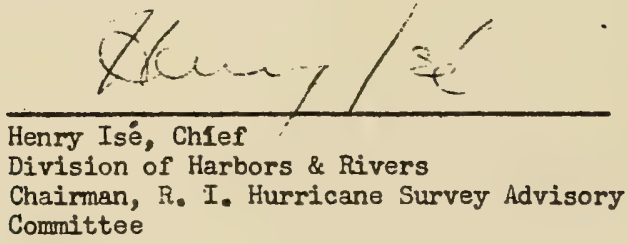





\section{DEPARTMENT OF \\ HEALTH, EDUCATION, AND WELFARE \\ REGIONAL OFFICE}

PUBLIC HEALTH SERVICE

Region II

42 Broaduay

iieu York 4, N.Y.

$24: S E$

February 7, 1957

Mr. Wesley Restall

Assistant Chief, Engineering Division

New England Division

Corps of Engineers, U. S. Army

150 Causmrar Street

Boston 14, Massachusetts

Dear Ir. Restall:

Reference is made to our recent, telephone conversation relative to your request for our comments on the effects of the proposed hurricane structures for Providence, Rhode Island, and Narragansett Bay on water pollution control problems. Our report wil1 be furnished to you short1y after March 1, 1957.

For the Regional Engineer.

Sincerely yours,

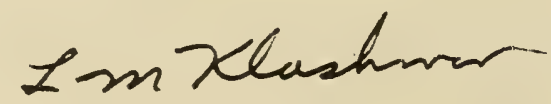

Lester M. Klashman

Acting Assistant Regional Engineer

Water Supply and Water Pollution Control 



\section{Statement of \\ Division of Sanitary Engineering \\ Rhode Island Department of Health}

On Proposed Hurricane Prevention For Narragansett 3ay

Frepared for hearing of Division Engineer, Corps of Engineers, U. S. Army at Providence on October 1, 1956.

This statement is submitted as a result of the receipt, very recently, from the office of the Division Engineer, Corps of Lngineers, U. S. Army, of information relative to studies of hurricane barriers in Narragansett Bay. It appears that these studies have led to the belief that two plans have particular merit:

1. An Upper Bay Barrier at Fox Point with sluice gates to pass normal river and tidal flows

2. Lower Bay Barriers constructed of rock, with navigation opening, which it has been estimated will restrict the tidal flow under ordinary conditions up to thirty five percent.

The proposal for the Lower Bay Barriers is of great concern to the Division of Sanitary Engineering because of the affect the reduction in tidal flow will have on the state's water pollution control program, particularly in Upper Narragansett Bay areas.

Sewage and industrial waste treatment works constructed for water pollution control are ordinarily designed on the premise that the treated wastes when discharged will be diluted by the receiving water, the greater the dilution the better. To provide such a high degree of treatment that no dilution would be necessary would be impractical if not impossible; the cost of such treatment would be prohibitive. Since the sewer systems of such cities as Providence and Pawtuciet are designed to receive storm water as well as sewage, much of the sewage is discharged into the waters of the state untreated during storms 

because neither the sewer systems nor the sewage treatment facilities are of large enough capacity to handle all the combined sewage and storm water entering the sewers. To separate storm water from the sanitary sewers in these cities would be an undertaking of exceedingly high cost.

Because of the very limited dilution available for wastes emptied into the waters of the Upper Bay or tributaries, the highest feasible degree of sewage treatment is required. These waters receive the sewage and wastes from the densely populated and highly industrialized cominunities of the state, the industrial wastes here discharged are difficult to purify and the results of conventional purification processes are not as good as would be desired. This places a greater demand for water for dilution.

The water that is available for dilution in the Upper Bay area, is made up almost wholly of water carried into the area by the tides. For example in the area north of Fields point where most of the sewage of the state must be discharged, river discharge during the dry summer months contributes only about four percent of the total dilution water. If we consider the dilution available north of Conimicut and Nayat Points the dilution afforded by river discharge is only an insignificant fraction of the total dilution water available.

The dilution water available in the Upper Bay is now meager and the problem of sewage disposal is a most difficult one; if the presently available water for dilution and dispersion is reduced by, roughly,. one third, the pollution problem will be made a far more serious one than it is now.

The time provided for an evaluation of this latest proposal which differs from earlier ones in that it restricts tidal flow substantiall! 

has not been sufficient to permit the presentation of more supporting data. It is desired to point out however that the United States Public Health Service with its highly specialized stream pollution investigation facilities at Cincinnati, Chio has been requested to collaborate with the Division of Sanitary Engineering in attempting to forecast as precisely as possible the likely affect of the Lower Bay Barriers on the pollution of Narragansett Bay. That agency is working on the matter, but will require more time to study it and prepare a report, than this hearing permitted. It is requested that an opportunity be granted to submit this report at a later date.

It appears that the Lower Bay Barrier Plan as presently conceived will make the control of pollution in Narragansett Bay far more difficult to realize than at present because of the resulting reduction in normal tidal water movement.

It is urged that further consideration be given only to types of flood control barriers that will not produce a significant reduction in the tidal prism in Narragansett Bay.

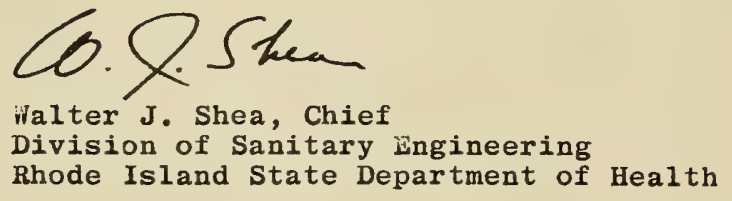


THE COMMONWEALTH OF MASSACHUSETTS

EXECUTIVE DEPARTMENT

STATE HOUSE, BOSTON

December 13,1956

Brigadier General Robert J. Fleming, Jr. Corps of Engineers

150 Causeway street

Boston 14, Massachusetts

\section{Subject: Narragansett Bay Hurricane Protection study}

Dear Genera1 Fleming:

Nassachusetts state officials have been reviewing, after a cooperative meeting with menbers of your ifurricane Study Section, the proposals for protection in Narragansett Bay.

As a result of these studies it is our general opinion that the principles involved in the Narragansett program are sound but that detailed studies of several matters will have to be carried out before several administrative agencies in the state can give their unqualified support. of particular interest are the matters of pollution and fisheries. Dur Department of Public Health is disturbed as to the impact of a reduction in salinity in Narragansett Lay and feels that this and the reduced changes in water require further careful analysis. In the same general vein the Department of Natural Resources, through its Division of Yarine Fisheries, is worried about the extent of the damage which might be done to various aspects under their jurisdiction. On the basis of these hesitancies I would like to endorse the principle of the Narragansett Bay IIurricane Project but urge that more extensive and more detailed studies in the directions above noted be made. If additional funds will be required for these further studies, I would aporeciate the opportunity of knowing about it so that I might have the chance to express my endorsement of such studies. 

Brig. Gen. Flemming $\quad-2-\quad 12 / 13 / 56$

I look forward to a resolution of these problems and, upon being presented with the information which I hope will show that they are not insuperable, that the Commonwealth will be able to express its total endorsement of the project.

Sincere1y yours,

$\mathrm{CAH} / \mathrm{mgp}$

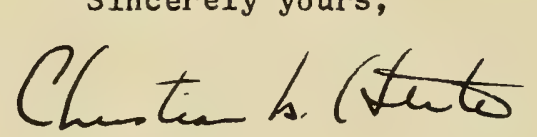



Excerpt from report by 11.5 . Fish and rildifse semice, vetober 1356

\section{CONCLUSIONS}

I. According to published statistics of the Fish and Widilie Service, the value of marine fish landed commercially In Rhode Isiand was $\$ 4,302,000$ in 1954 A significant portion of this procuction came from Narragansett Bayc A personal interw lew survey of about 5,000 aport fishermen on Narragansett Bay during the sumner of $1956+1215$ ated that this fishery represents an important segment of the total marine spert frishery of Rhode Island. The 1955 report of the New England-New York Inter-Agency Commitee showed an estimated annual experditure of \$3,024,375 for marine sport fishing in Fhode Islando Frurther analysis of data collected on the Narragansett Bay sport fishing 1 s expected to indicate that a substantial portion of these total Finco Istard expenditures are related to this Bay fisheryo

2. Narragangett Bay as a hatching and rursery srea foy raraus species of finfishes contributes stocks to the ocean fishery dying outside the Bay。 The magnitude of the contribution may be great, and sholid be determined prior to barrier construetion.

3. The work completed thus far provides a valuable gssessant of preproject conditions of a segment of the fisheryo These data will be of considerable value for comparative purposes whenerer the need arises for a postproject inventory following the instaliation of control bark riers。

40 The inventories conducted thus far are basic to deterwing the effects of the control barriers on the fizheryo Additional gtudies wil

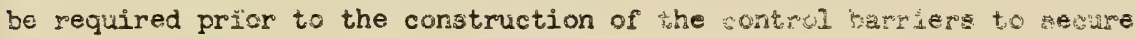



the necssary detailed knowledge of the effects of changes of salin= Ity, temperature, oxygen, pollution, currents, and silting wpon fin= fish and shellfish。

5. The Fish and Wildiffe Service considers that a barrier in the Fox Point Area will have no significant effect on the fishery resources of Narragansett Bay。

\section{RECOMMENDATIONS}

\section{It is recommended:}

1. That studies be made of the effects which hurricane control barriers in the lower Bay may have upon the fishery resources of Narragansett Bay as follows:

a. Effect on hard clam of salinity changes caused by lowor Bay barriers.

b. Effect on hard clam of silt redistribution caused by those barriers。

c. Effect on hard clam of temperature changes caused by those barriers 。

d. Effect on those barriers upon the entrance and egress of varicus species of young ocean fish which depend on Narragansett Bay for a nursery.

e. Effect on hard clam of changes in dissolved oxygen caused by lower Bay barrierz.

f. Effect on hard clam of changes in currents caused by those barriers. 

go Effect on winter and summer flounders of sediment redistribution caused by those barriers。

h. Effect on winter and sumer flounders of temperature changes caused by those barriers.

1. Effect on movements of summer and winter flounders of sill construction in those barriers。

jo Effect on summer flounders of salinity changes caused by those barriers。

k. Effect on bottom organisms of changing conditions caused by those barriers.

Recommendations for structural changes in the lower Bay barrorers might be made to the Corps of Engineers from time to time during the planning and construction period followịng formulation of a well fourided opinion by the Fish and Wildlife Service on any or a group of the above effects。

2. That the current inventory studies be extended to secure the important second consecutive year of data on the fisheries of Narragansett, Bay。 This inventory would include a continuation of the quahog and sport fishing surveys which were undertaken this year. The inventory should include a study to indicato production of the Bay above the barrier sites。

3. That existing studies be augmented to secure the best estimates of the tolerances of the more important finfish and shellfish to changes in salinity, temperature, oxygen, pollution, currents, and silting。 Such studies should begin with the presentation of detalled plans, time estimates, cost estimates and completion dates by fishery per- 

sonnel detalled to the work. It is believed that the factors of temperature, salinity and silting can be satisfactorily determined for the barriers themselves in the Narragansett Bay model in the Waterways Experiment Station at Vicksburg, Mississippi gnd it is recommended that the Corps of Engineers complete these studies by June 30,1957 . It will be necessary to conduct, at varicus Fish and Wildlife Service installations, studies in which the species of fish involved would be subjected to various controlled enwironmental conditions。

4. That the macroinvertebrate life of the bottom of the Bay be afforded detailed study to determine its relative abundance ano composition. This bottom fauna study would also represent an inventory and would serve to round out the preprofect picture of the Bay"s resources prior to construction of barriers. Furthernore, it is possibie that certain of these bottom-dwelling forms may reveal themseres as indicator organisms which could be emploged to foretell or confirm damages or benefits which may accrue from the congtruction of the project barriers.

5. That additional studies be undertaken to determine the imp: tance of the Bay to populations of winter flounder. It is known that the Bay comprises a spawning and nursery area for this species, This knowledge is not well defined, however, and mach more data are required to determine the precise relationship of the winter flounder to the Bay, and how this relationship could be affected by the construction of hurricane damage control barriers. 6. That, in addition to the winter flounder study, an investigation be 

mate to determine the importance of the Bay in maintaining stocks of various oceanic species. It is believed that valuable finfish of the Atlantic Ocean require access to the Bay during portions of their life cycles for spawning or rearing their young.

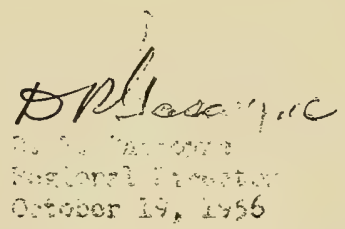





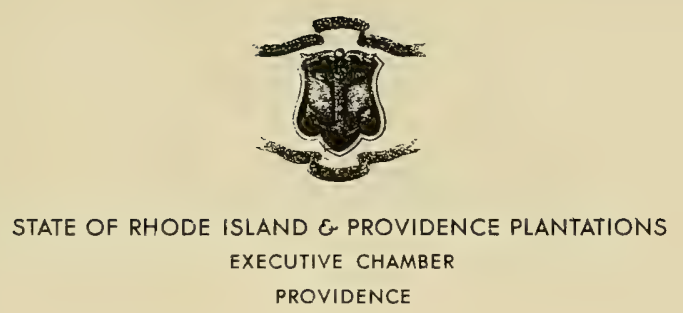

PROVIDENCE

DENNIS J.ROBERTS

GOVERNOR

February 2, 1957

Brigadier General Robert J. Fleming

Division Engineer

New England Division

150 Causeway Street

Boston 14, Massachusetts

Dear General Fleming:

I was pleased to receive your letter of January 26th and to note the progress which you have made on the Hurricane Survey of Narragansett Bay. The recommendations which you stated seem to me to be very sound. As you know, at the public hearing which was held on this project in Providence, October 1, 1956, I stated my support for an adequate system of Hurricane Barriers.

Although there are some details to be worked out concerning the financing, I approve of the general lines of your recommendations, and believe that the State of Rhode Island will participate in the project under the formula set out in your letter.

With kindest personal regards, I am

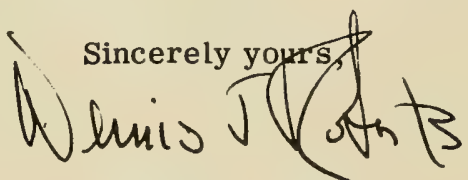

Dennis J. Roberts

Governor 



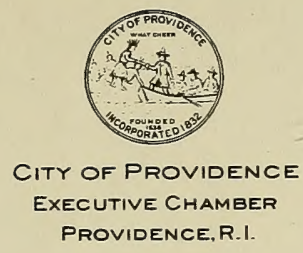

WALTER H. REYNOLDS

MAYOR

File No. NEDGW

January 29, 1957

Mr. Robert J. Fleming, Jr.

Brigadier General, U. S. Army

Office of the Division Engineer

150 Causeway Street

Boston 14, Massachusetis

Dear General Fleming:

I wish to thank you for your kind letter of January 26, 1957 advising me in advance of the recommendations which you propose to make as a part of the interim report on the Hurricane Survey, Narragansett Bay, Rhode Island and Massachusetts.

As I understand your recommendations with respect to the Upper Bay barrier at Fox Point: (1) You are proposing that the local government, which in this case is Providence and/or the State of Rhode Island, be responsible for approximately $\$ 200,000$, representing cost of land and rights-of-way and for another $\$ 120,000$ for relocations which may be necessary. (2) Except for the se approximate amounts the total first cost estimated to amount to $\$ 16,500,000$ is recommended entirely for federal financing. (3) After construction local interests, that is Providence and/or the State of Rhode Island, would be expected to meet the full cost of operation and maintenance estimated to be $\$ 134,000$ annually, exclusive of any standby charges for electric service.

If I have read correctly the propoșals relating directly to Providençe as contained in your letter of January 26,1957 , and which I have restated above, then I can give you assurance of my belief that the local interests will be happy to participate in this portion of the project along the general lines recommended.

Very truly yours,

Walter re Reynolds

Mayor of Providence

WHR:vmb 



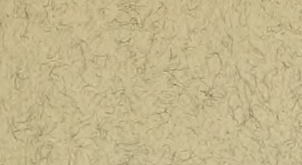

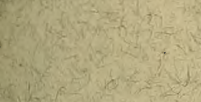

$\frac{2}{4}$

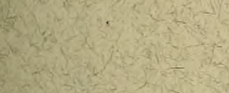

2. 0 (x)

$48,-3$

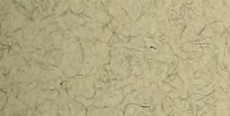

(t)

6

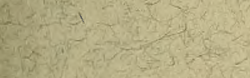

Neve in

(1)

$\frac{1}{2}+2=3$

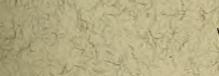

thing in

(3)

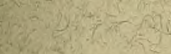

(1)

(6)

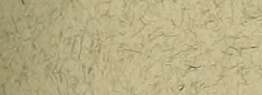

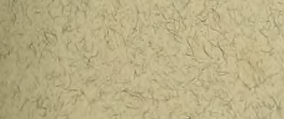


